ESTIMATES OF FRESHWATER STORAGE AND POTENTIAL NATURAL RECHARGE FOR PRINCIPAL AQUIFERS IN KANSAS

By Cristi V. Hansen

U.S. GEOLOGICAL SURVEY

Water-Resources Investigations Report 87-4230

Prepared in cooperation with the KANSAS WATER OFFICE

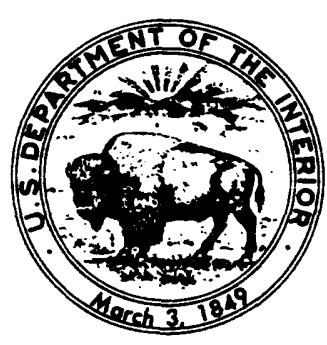

Lawrence, Kansas 


\section{U.S.DEPARTMENT OF THE INTE RIOR \\ MANUEL LUJAN, JR., Secretary}

\section{U.S. GEOLOGICAL SURVEY}

Dallas L. Peck, Director

For further information write to:

District Chief

U.S. Geological Survey 4821 Quail Crest Place Lawrence, Kansas 66049
Copies of this report can be purchased from:

U.S. Geological Survey

Books and Open-File Reports

Denver Federal Center, Building 810

Box 25425

Denver, Colorado 80225 


\section{CONTENTS}

Abstract $\quad \ldots \ldots \ldots \ldots \ldots \ldots \ldots \ldots \ldots \ldots \ldots \ldots \ldots \ldots \ldots \ldots \ldots \ldots \ldots \ldots \ldots$

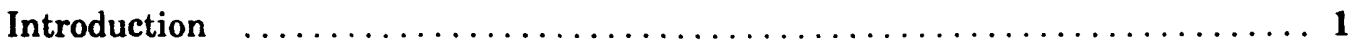

Background $\ldots \ldots \ldots \ldots \ldots \ldots \ldots \ldots \ldots \ldots \ldots \ldots \ldots \ldots \ldots \ldots \ldots \ldots \ldots \ldots$

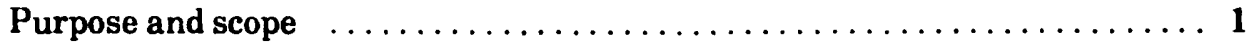

Acknowledgments $\ldots \ldots \ldots \ldots \ldots \ldots \ldots \ldots \ldots \ldots \ldots \ldots \ldots \ldots \ldots$

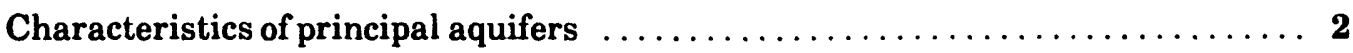

Aquifers in unconsolidated deposits $\ldots \ldots \ldots \ldots \ldots \ldots \ldots \ldots \ldots \ldots$

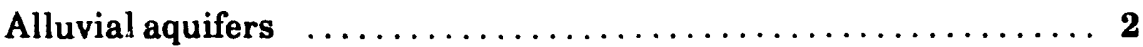

Glacial-drift aquifers $\ldots \ldots \ldots \ldots \ldots \ldots \ldots \ldots \ldots \ldots \ldots \ldots \ldots$

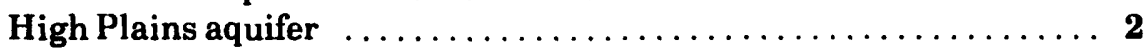

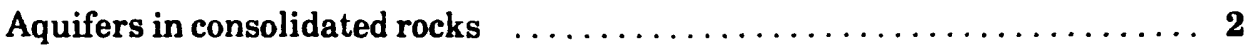

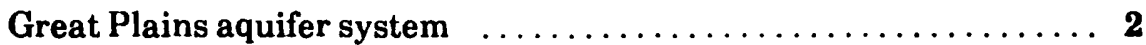

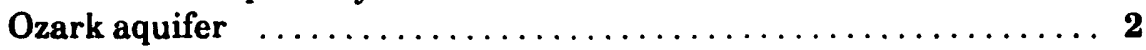

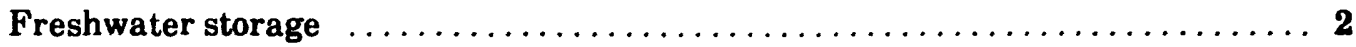

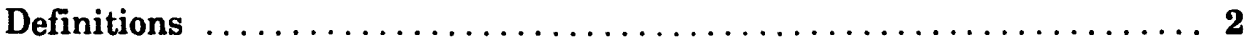

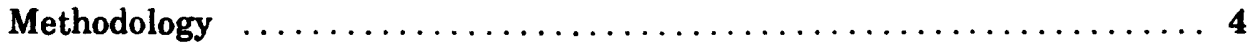

Factors affecting volume of freshwater in storage $\ldots \ldots \ldots \ldots \ldots \ldots$

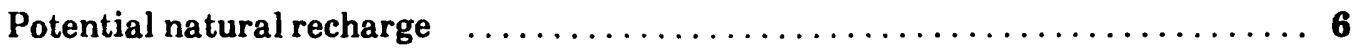

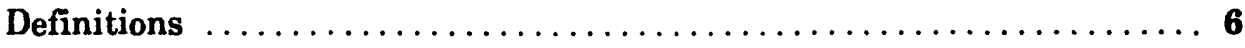

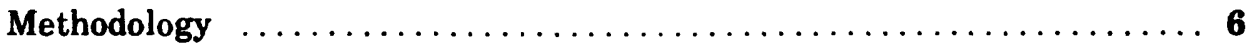

Factors affecting potential natural recharge $\ldots \ldots \ldots \ldots \ldots \ldots \ldots, 8$

Estimates of freshwater storage and potential natural recharge $\ldots \ldots \ldots \ldots \ldots 9$

Alluvial aquifers $\ldots \ldots \ldots \ldots \ldots \ldots \ldots \ldots \ldots \ldots \ldots \ldots \ldots \ldots \ldots$

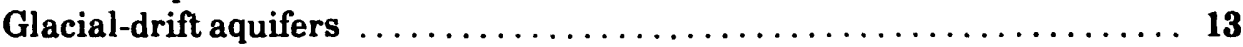

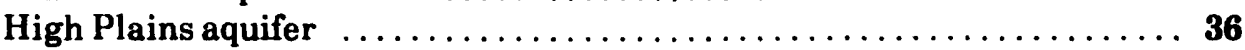

Great Plains aquifer system $\ldots \ldots \ldots \ldots \ldots \ldots \ldots \ldots \ldots \ldots \ldots \ldots \ldots \ldots$

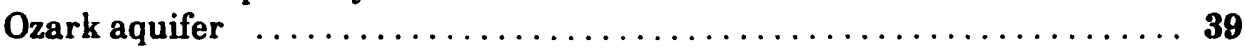

Summary and conclusions $\ldots \ldots \ldots \ldots \ldots \ldots \ldots \ldots \ldots \ldots \ldots \ldots \ldots \ldots$

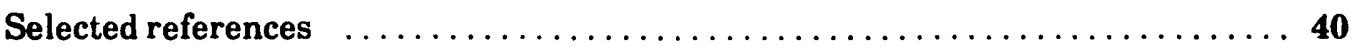

Supplemental information $\ldots \ldots \ldots \ldots \ldots \ldots \ldots \ldots \ldots \ldots \ldots \ldots \ldots \ldots$ 


\section{CONTENTS--Continued}

Plate

1. Map showing saturated thickness of alluvial, glacial-drift, and High Plains aquifers in Kansas $\ldots \ldots \ldots \ldots \ldots \ldots \ldots \ldots$ (in pocket)

2. Map showing saturated thickness of Great Plains aquifer system and Ozark aquifer in Kansas ..................... (in pocket)

3. Map showing specific yield of alluvial, glacial-drift, and High Plains aquifers in Kansas $\ldots \ldots \ldots \ldots \ldots \ldots \ldots \ldots \ldots \ldots \ldots \ldots \ldots \ldots$ (in pocket)

4. Map showing areas of recharge to principal aquifers, mean annual potential natural recharge, and mean annual precipitation in Kansas

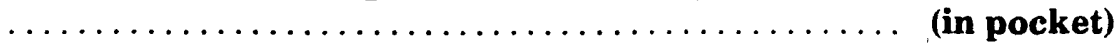

Figure

Page

1. Map showing general availability of ground water

2. Map showing a verage annual potential evapotranspiration, 1951-80 10

3-8. Maps showing (A) area and (B) volume of freshwater in storage in:

3. Principal aquifers $\ldots \ldots \ldots \ldots \ldots \ldots \ldots \ldots \ldots \ldots \ldots \ldots \ldots$

4. Alluvial aquifers $\ldots \ldots \ldots \ldots \ldots \ldots \ldots \ldots \ldots \ldots \ldots \ldots$

5. Glacial-drift aquifers $\ldots \ldots \ldots \ldots \ldots \ldots \ldots \ldots \ldots \ldots \ldots$

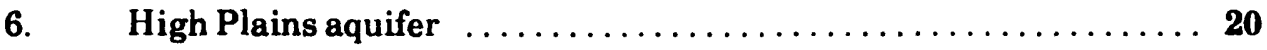

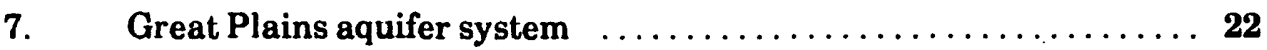

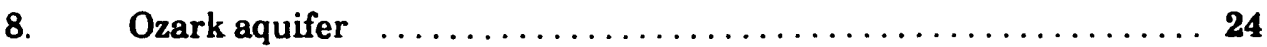

9-13. Maps showing (A) area and (B) volume of potential natural recharge to:

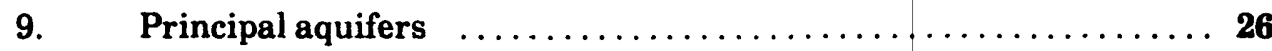

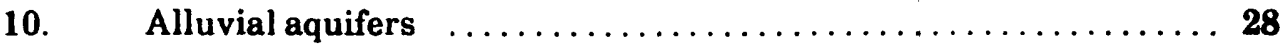

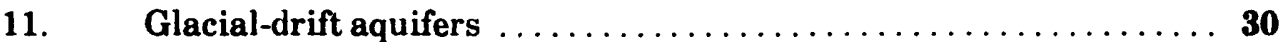

12. High Plains aquifer $\ldots \ldots \ldots \ldots \ldots \ldots \ldots \ldots \ldots \ldots \ldots \ldots \ldots \ldots \ldots$

13. Great Plains aquifer system $\ldots \ldots \ldots \ldots \ldots \ldots \ldots \ldots \ldots \ldots$

14. Map showing specific yield of Great Plains aquifer system . . . . 38

15. Map showing major river-basin divisions $\ldots \ldots \ldots \ldots \ldots \ldots \ldots$ 


\section{CONTENTS--Continued}

Table

Page

1. Principal aquifers in Kansas and their hydrologic characteristics .... 3

2. Summary of freshwater storage and potential natural recharge for principal aquifers in Kansas $\ldots \ldots \ldots \ldots \ldots \ldots \ldots \ldots \ldots \ldots$

3. Estimated volume of freshwater in storage in the principal aquifers in Kansas ..................................47

4. Estimated volume of potential natural recharge to the principal aquifers in Kansas 74

\section{CONVERSION FACTORS}

$\begin{array}{lcl}\begin{array}{l}\text { Multiply } \\ \text { inch }\end{array} & \text { By } & \text { Toobtain } \\ \text { foot } & 25.4 & \text { millimeter } \\ \text { acre } & 0.3048 & \text { meter } \\ \text { acre-foot } & 4,047 & \text { square meter } \\ \text { inch per year } & 1,233 & \text { cubic meter } \\ \text { foot per year } & 25.4 & \text { millimeter per year } \\ \text { acre-foot per year } & 0.3048 & \text { meter per year } \\ \text { gallon per minute } & 1,233 & \text { cubic meter per year }\end{array}$




\title{
Estimates of Freshwater Storage and Potential Natural Recharge for Principal Aquifers in Kansas
}

\author{
By Cristi V. Hansen
}

\begin{abstract}
The principal aquifers in Kansas are (1) alluvial aquifers, (2) glacial-drift aquifers, (3) the High Plains aquifer, (4) the Great Plains aquifer system, and (5) the Ozark aquifer. Freshwater (having a dissolved-solids concentration less than 1,000 milligrams per liter) in storage in all these aquifers is estimated to be $590,000,000$ acre-feet; the potential natural recharge is estimated to be $3,990,000$ acre-feet per year. Freshwater storage is estimated to be $12,700,000$ acre-feet for alluvial aquifers; $12,400,000$ acrefeet for glacial-drift aquifers; 267,000,000 acrefeet for the High Plains aquifer; 271,000,000 acre-feet for the Great Plains aquifer system; and 26,100,000 acre-feet for the Ozark aquifer. Potential natural recharge is estimated to be $1,470,000$ acre- feet per year to alluvial aquifers; 663,000 acre-feet per year to glacial-drift aquifers; $1,530,000$ acre-feet per year to the High Plains aquifer; and 323,000 acre-feet per year to the Great Plains aquifer system. There is no direct natural recharge to the Ozark aquifer.
\end{abstract}

Estimates of freshwater storage in the alluvial, glacial-drift, and High Plains aquifers are similar to those made by previous investigators; estimates of freshwater storage in the Great Plains aquifer system and Ozark aquifer were several times larger, probably due to differences in estimating saturated thickness. Estimates made during this study of potential natural recharge are similar to those made by previous investigators, except in western Kansas, where greater rates of recharge are estimated.

\section{INTRODUCTION}

\section{Background}

Ground water supplies 85 percent of the water needs of Kansas (Bevans and others, 1985), and the demand is increasing. In order to effectively and efficiently manage the State's ground-water resources, information is needed on the quantity of freshwater in storage and the quantity of potential natural recharge to these aquifers. Estimates of saturated thickness, specific yield, water in storage, and recharge previously have been made in parts of Kansas for several aquifers but not for all the aquifers statewide.

\section{Purpose and Scope}

The purpose of this report is to estimate freshwater storage and potential natural recharge for the principal aquifers in Kansas. Available information on saturated thickness, specific yield, water in storage, and recharge for the principal aquifers in Kansas were consolidated and updated. Where no information was previously available, new estimates were made. This report is based on a July 1985 to July 1986 investigation conducted by the U.S. Geological Survey in cooperation with the Kansas Water Office.

\section{Acknowledgments}

The author wishes to thank Jane E. Denne of the Kansas Geological Survey for providing information related to the saturated thickness of glacial deposits in northeastern Kansas. Special appreciation is extended to Jack T. Dugan of the U.S. Geological Survey for his help with that part of the study and report dealing with potential natural recharge. 


\section{CHARACTERISTICS OF PRINCIPAL AQUIFERS}

The principal aquifers in Kansas can be divided into two groups. The first group is made up of aquifers in relatively young, unconsolidated deposits that usually occur under unconfined conditions. This group includes aquifers in alluvial and glacial-drift deposits and the High Plains aquifer (table 1). The aquifers in unconsolidated deposits are the most extensively used in the State because they are at shallower depths, tend to have better quality water, and generally have larger yields. The second group consists of aquifers in older, consolidated rocks that usually occur under confined conditions. The Great Plains aquifer system and the Ozark aquifer are in this group (table 1). The Great Plains aquifer system and the Ozark aquifer are not used extensively because better quality water usually can be found in shallower, unconsolidated deposits, but these aquifers may be used more in the future.

\section{Aquifers in Unconsolidated Deposits}

\section{Alluvial Aquifers}

Alluvial aquifers consist of unconsolidated sand, gravel, silt, and clay of Quaternary age. These deposits are present in most stream valleys (plate 1). They are especially important in eastern Kansas where other major aquifers are not present.

\section{Glacial-Drift Aquifers}

Glacial-drift aquifers consist of unconsolidated till, outwash, and loess of Pleistocene age. These deposits are present in northeastern Kansas where they are important sources of water (plate 1).

\section{High Plains Aquifer}

The High Plains aquifer consists of unconsolidated Pleistocene, Pliocene, and Miocene silt, clay, sand, and gravel of fluvial and eolian origin and any alluvial deposits directly overlying the unconsolidated Pleistocene, Pliocene, and Miocene deposits. The High Plains aquifer is present throughout much of western Kansas (plate 1) and is used extensively there.

\section{Aquifers in Consolidated Rocks}

\section{Great Plains Aquifer System}

The Great Plains aquifer system consists of loosely consolidated sandstone, siltstone, and shale of Early Cretaceous age (Jorgensen, Helgesen, and Imes, in press). It includes the Dakota Formation, Kiowa Shale, and Cheyenne Sandstone. These rocks are present throughout much of central and western Kansas (plate 2). The Great Plains aquifer system is an important source of water in parts of north-central and central Kansas where the High Plains aquifer is thin or absent.

\section{Ozark Aquifer}

The Ozark aquifer consists of weathered and sandy dolomite and limestone of Ordovician and Cambrian age and includes the Arbuckle Group (Jorgensen, Helgesen, and Imes, in press). It is an important aquifer in extreme southeastern Kansas (plate 2).

\section{FRESHWATER STORAGE}

\section{Definitions}

Water in storage is defined in this report as the amount of water available for use in an aquifer. Water in storage is dependent on two factors--the volume of the saturated part of the aquifer and the storage coefficient of the aquifer.

The volume of saturated aquifer material is estimated from the areal extent of the saturated part of an aquifer and the thickness of the saturated part. For this study, only the part of the aquifer saturated with freshwater was considered. The definition of freshwater was chosen to be consistent with that used by the State of Kansas. Freshwater is defined by the State as water with a dissolved-solids concentration of 1,000 milligrams per liter $(\mathrm{mg} / \mathrm{L})$ or less (Kansas Department of Health and Environment, 1984; 1985).

The extent of an aquifer is limited in this 


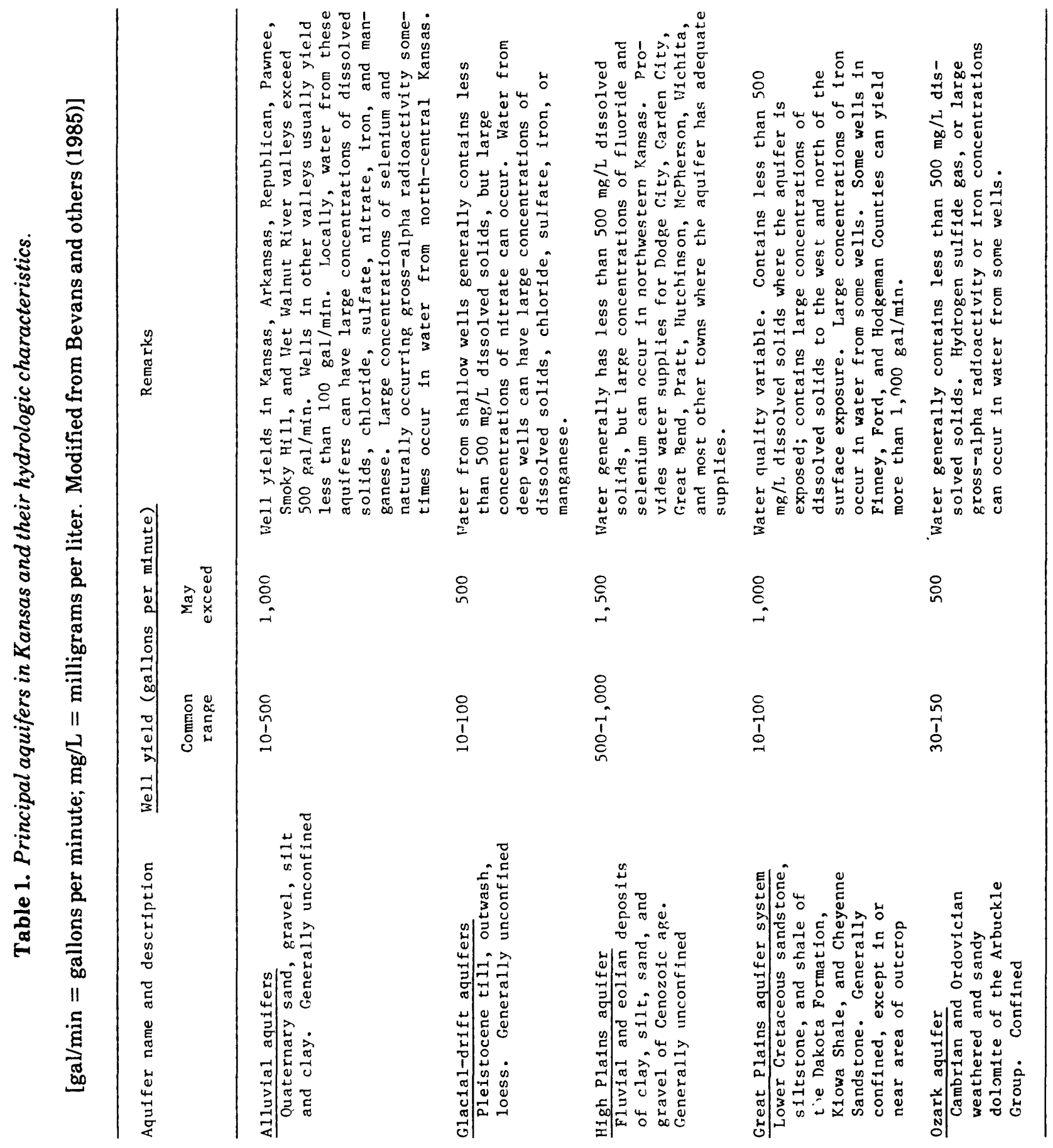


study to where the aquifer is saturated with freshwater. The saturated thickness of an unconfined aquifer is equal to the thickness of the part of the aquifer that lies below the water table. Where an aquifer is confined, the entire thickness of the aquifer is saturated.

The storage coefficient is the volume of water that an aquifer releases from or takes into storage per unit surface area of aquifer per unit change in hydraulic head (Lohman and others, 1972). In confined aquifers, the storage coefficient is very small, about 0.000001 per foot of aquifer thickness (Lohman, 1979). As the water level is drawn below the top of the aquifer, the aquifer becomes unconfined. The storage coefficient of an unconfined aquifer is much larger, about 0.2 per foot of saturated aquifer thickness. Although the amount of water yielded by an aquifer under confined conditions can be significant, in this study, the amount of water yielded by an aquifer when it is confined was found to be so much smaller than the amount yielded while under unconfined conditions (less than 0.02 percent of the total) that the confined water was ignored. In an aquifer under unconfined conditions, the storage coefficient is virtually equivalent to the specific yield of the aquifer.

Porosity is the ratio of the volume of the rock or soil interstices (openings) to the total volume of the rock or soil (Lohman and others, 1972). If the rock or soil is saturated, these interstices are filled with water. Specific yield is the ratio of (1) the volume of water which the rock or soil, after being saturated, will yield by gravity to (2) the volume of rock or soil (Lohman and others, 1972). Most of the interstitial water will drain from the deposits, but some of the water will be retained by capillary forces (Heath, 1983). The specific yield of an aquifer is always somewhat less than the porosity of the deposits, unless there are other factors involved, such as unpredictable fractures and solution openings.

\section{Methodology}

The extent of each aquifer identified in this report was based on previously published maps. Areas of an aquifer with no saturated thickness were not considered, nor were the areas where the aquifer does not contain freshwater.
For unconfined aquifers, saturated thickness was estimated from previously published maps of saturated thickness or from maps of the altitude of the water table and of the bottom of the aquifer. Where possible, these maps were updated with data from recent well measurements. If no maps were available, a map of saturated thickness was constructed based mainly on well information. Previously constructed maps of the thickness of the confined aquifers were used as saturated-thickness maps for those aquifers.

Where previously published values of specific yield were available, they were used. Where previously published information on specific yield of an aquifer was unavailable, specific yield was estimated by multiplying the percentage of the aquifer containing permeable material by the specific yield of the material. If this information was unavailable, the specific yield was estimated from the average porosity of the aquifer.

Considering the factors just mentioned, it is possible to use a simplified equation to estimate the volume of water in storage:

$$
\begin{aligned}
\text { storage }= & (\text { volume of saturated deposits }) X \\
& (\text { specific yield }),
\end{aligned}
$$

where

storage $=$ volume of freshwater in storage, in acre-feet;

volume of saturated deposits $=$ volume of aquifer saturated with freshwater, in acre-feet; and

specific yield $=$ specific yield of the aquifer, dimensionless.

The estimate of the volume of water in storage was computed by determining the area within each saturated-thickness contour (plates 1 and 2) and then making a graph of the volume of saturated deposits by plotting the area within each contour interval against the value of the contour. The area below the curve of this graph is equal to the volume of saturated deposits. If it was not possible to construct a graph of the 
volume of saturated deposits because there was only one saturated-thickness contour in the area, the volume of saturated deposits was estimated by multiplying the area within the contour by the average saturated thickness. If no other information was available, the average saturated thickness was estimated to be equal to the value of the enclosing contour plus onefourth of the contour interval [ for example, if all the area is within an 80 -foot contour and the contour interval is 40 feet, the average saturated thickness $=80+(1 / 4 \times 40)=90$ feet $]$. The volume of saturated deposits then was multiplied by the specific yield of the aquifer (plates 2 and 3 ) for an estimate of the volume of freshwater in the aquifer.

\section{Factors Affecting Volume of Fresh- water in Storage}

All aquifers contain some relatively impermeable material that will yield little water. If the proportion of relatively impermeable material is known, the aquifer's effective thickness can be determined. Effective thickness is that part of the saturated thickness of an aquifer that will yield most of the water. Although effective thickness would be more useful than saturated thickness for determining the volume of aquifer material that will yield water, it generally was not used in this study because not enough information was available. Available estimates of effective thickness are variable. Effective thickness for the High Plains aquifer in Finney, Haskell, and Kearny Counties has been estimated to range from 29 to 100 percent and to average about 70 percent of saturated thickness (Gutentag, Lobmeyer, McGovern, and Long, 1972; Gutentag, Lobmeyer, and McGovern, 1972; Gutentag and Stullken, 1974). Keene and Bayne (1977) have estimated that only 30 percent of the upper part of the Great Plains aquifer system is relatively permeable material, while J.O. Helgesen (U.S. Geological Survey, written commun., 1987) estimated 50 percent of the Great Plains aquifer system in Kansas is relatively permeable material.

Climate can affect the volume of water in storage by affecting the saturated thickness of an unconfined aquifer. The saturated thickness of an aquifer can vary through time as the water table within the aquifer rises and falls. During times of plentiful precipitation (increased recharge), the water table may rise and increase the aquifer's saturated thickness, but during times of drought (negligible recharge) the water table may fall and reduce the aquifer's saturated thickness. These changes will be most dramatic in thin aquifers, such as the thinner alluvial aquifers, and may cause them to become undependable sources of water during times of drought (Morton and Fader, 1975).

The effects of increasing depth on water quality in the aquifers were not investigated in this study. It is likely that in some areas that are shown as having dissolved solids of less than $1,000 \mathrm{mg} / \mathrm{L}$ (plates 1 and 2) the water may actually have larger dissolved-solids concentrations at greater depths in the aquifer. This is especially true where Permian rocks containing greatly mineralized water underlie parts of the principal aquifers in central and southwestern Kansas (Leonard and Kleinschmidt, 1976; Hathaway, Carr, Flanagan, Galle, Waugh, Dickey, and Magnuson, 1978; Hathaway, Galle, Waugh, and Dickey, 1978) or where leakage of oilfield brines has caused contamination (Leonard and Kleinschmidt, 1976; Hathaway and others, 1981).

The use of a dissolved-solids concentration of $1,000 \mathrm{mg} / \mathrm{L}$ as the upper limit of freshwater does not mean that all water with concentrations less than that limit is suitable for all uses or that all water with concentrations greater than that limit is unusable. The State of Kansas recommends that water with a dissolved-solids concentration greater than $1,000 \mathrm{mg} / \mathrm{L}$ not be used for drinking water, but in some areas of the State where better quality water is unavailable, water with dissolved solids greater than 2,000 $\mathrm{mg} / \mathrm{L}$ is used for drinking water. The concentration of individual constituents can make water unsuitable for specific uses. For drinking water, a large sulfate concentration causes the water to have a laxative effect. Large concentrations of iron impart a bad taste and tend to stain laundry and plumbing fixtures. Large fluoride concentrations cause mottling of teeth. Large nitrate concentrations may cause methemoglobinemia in infants. Concentrations of any constituent above the limits recommended by the U.S. Environmental Protection Agency (1986a and b) can make the water unsuitable for 
a particular use no matter what the dissolvedsolids concentration is. The suitability of water for irrigation is dependent not just on the dissolved-solids concentrations but also on the sodium-adsorption ratio, soil type, and drainage. In Hamilton County, a calcium sodium sulfate type water with dissolved-solids concentrations greater than $4,000 \mathrm{mg} / \mathrm{L}$ is used for irrigation with few problems because the soil is well drained (Lobmeyer and Sauer, 1974). Suitability of water for industrial uses is dependent on the type of industry. For example, chemical quality of water generally is not important for concentrating ores, but extremely pure water is needed for nuclear reactors (Hem, 1985).

Well yields do not affect the volume of water in storage, but they do affect the rate at which the water can be withdrawn. The yield of a well depends upon the thickness and permeability of the aquifer, whether the aquifer is confined or not, the degree of penetration of the aquifer by the well, the diameter of the well, the efficiency of the pump and well screen, and many other factors. Because of the wide range in these factors and their effects, there is no accurate way to predict the yield of a well.

Aquifers may contain large volumes of water in storage, but wells tapping these aquifers may not yield large volumes of water. This may be especially true in areas where an aquifer is confined or semiconfined. If an aquifer is confined or semiconfined, all or most of the water being released from the aquifer is due to the expansion of the water and compaction of the aquifer as the confining pressure is released. For that reason, confined and semiconfined aquifers will yield water only at a rate of about 0.01 to 0.0001 of the rate the same aquifer would yield if it were unconfined (Heath, 1983). The thickness of an aquifer also can affect the rate at which it will yield water. The thicker the aquifer is, if all other conditions remain the same, the more water it will yield to a fully penetrating well. A generalized map of well yield is shown in figure 1. This map shows that properly constructed and located wells may be expected to have greater yield in western and southeastern Kansas and along the major river valleys than in the rest of the State. Local variations in the geology may make the yield of individual wells larger or smaller than those shown on the map.
Even in areas with large well yields it is not possible to pump out all the water that theoretically would drain by gravity from saturated deposits or rocks, nor is it economically feasible. Estimates of the part of the volume of water in storage that is available for development range from 60 percent (McClain and others, 1975) to 80 percent (Fader and Stullken, 1978). An intermediate value of twothirds ( 66.7 percent) has been used by the Kansas Water Office (1984).

\section{POTENTIAL NATURAL RECHARGE}

\section{Definitions}

Recharge is defined in this report as the infiltration of water across the water table into the saturated zone. In this study, the only type of recharge considered was potential natural recharge. Potential natural recharge is recharge from precipitation to the water table in an aquifer that directly underlies the soil at land surface. All precipitation was assumed to be freshwater with a dissolved-solids concentration less than $1,000 \mathrm{mg} / \mathrm{L}$. Return flow from irrigation and underflow from areas outside Kansas were not considered in estimating natural recharge for this study.

It is important to know the amount of recharge to an aquifer because if withdrawals exceed this amount, the water table in the aquifer (or pressure head, if the aquifer is confined) probably will decline. If this condition continues over a long enough period, parts of the aquifer may be dewatered and become unusable as a source of water.

\section{Methodology}

The area where natural recharge is taking place was determined by comparing the areas where each aquifer has some saturated thickness and the areas of outcrop shown on the State geologic map (Kansas Geological Survey, 1964). Where the aquifer has some saturated thickness and directly underlies the soil at land surface, natural recharge is possible.

There are few measured values of the rate of recharge available for Kansas, and those 


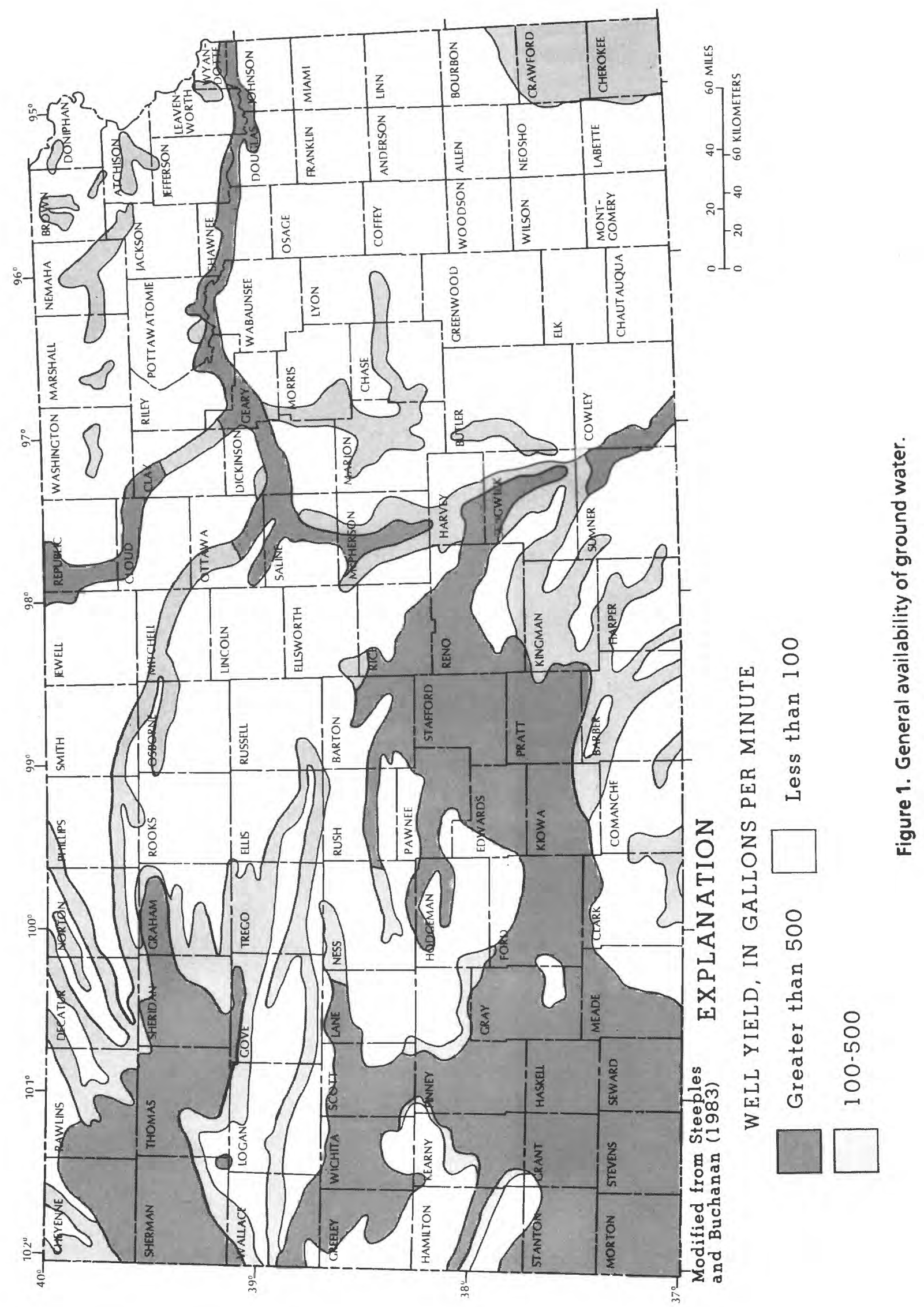


available are only applicable to limited areas. As a result, estimates of recharge usually are made using indirect methods. The best previous indirect estimates of the rate of recharge commonly were based on the amount of base flow in unregulated streams. Generally, this information also was unavailable, and the rate of recharge was estimated as a percentage of precipitation. Estimates of the rate of recharge also may come from studies that used waterbalance computer models to simulate hydrologic conditions. These models were not designed to calculate recharge, but recharge was one of the variables in the water-balance equation. As a result, recharge was estimated as any reasonable value that would balance the equation.

This study used a computer model that estimated the rate of potential natural recharge directly rather than as a part of a water-balance equation. The model calculated the rate of potential natural recharge from soil, vegetative, and climatic data. The model consisted of three programs. The first program used the JensenHaise solar-radiation method (Jensen and Haise, 1963; Jensen and others, 1970) to determine potential evapotranspiration (PET) from solar radiation, temperature, and humidity information. The second program was developed by the U.S. Bureau of Reclamation and modified by Lappala (1978) and Peckenpaugh and Dugan (1983) to account for the moisture entering, leaving, and remaining within the soil zone, based on the effects of vegetation and hydrologic characteristics of the soils and the data calculated by the PET program. The third program was modified from Peckenpaugh and Dugan (1983) to take point estimates of the mean annual rate of recharge from the soil-moisture program and make a weighted areal distribution of the estimated recharge data on the basis of land-use and soil patterns in the areas between these points.

The natural-recharge model had been used previously by the U.S. Geological Survey's Central Midwest regional aquifer system analysis (CMRASA) (Dugan and Peckenpaugh, 1985 ) to estimate the mean annual rate of recharge in much of eastern and central Kansas. The model was used in this study to estimate the rate of recharge in western and the remaining part of central Kansas after the appropriate data were collected. These results were combined with those from the CMRASA (J.T. Dugan, written commun., 1985) to make a generalized map showing the mean annual rate of recharge in Kansas.

To estimate the amount of recharge, a simplified equation was used:

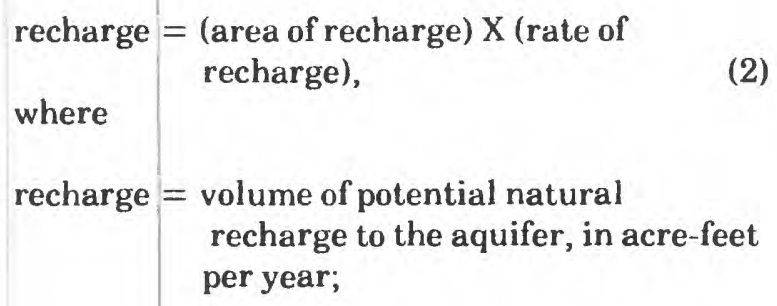

where

recharge $=$ volume of potential natural recharge to the aquifer, in acre-feet per year;

area of recharge $=$ area where the aquifer has some saturated thickness and directly underlies the soil at land surface, in acres; and

rate of recharge $=$ mean annual rate of potential natural recharge, in feet per year.

The estimate of the volume of potential natural recharge per year was computed by determining the area where the aquifer has some saturated thickness and directly underlies the soil at land surface (plate 4) and multiplying it by the rate of potential natural recharge estimated to the nearest 0.25 inch from the map showing the mean annual rate of potential natural recharge (plate 4 ).

\section{Factors Affecting Potential Natural Recharge}

The quantity of water from precipitation that becomes available for potential natural recharge is a function of a variety of environmental elements. These include the climate, soils, and land use or vegetation. These elements necessarily must be considered in calculating potential natural recharge.

Climate affects potential natural recharge in two ways. First, climate is comprised of a group of factors that affects consumptive water use or evapotranspiration. Potential evapotranspiration, which is essentially consumptive water use under conditions where the availability of water is a nonlimiting factor, is a 
function of solar radiation, temperature, humidity, and wind velocity. Potential evapotranspiration shows a significant increase across Kansas, from approximately 42 inches annually in the northeast to more than 64 inches in the southwest (fig. 2). This factor indicates that consumptive water requirements are much greater in southwestern Kansas; therefore, less water would be available for recharge. A second climatic factor, precipitation, was considered as the only source of water for potential natural recharge in this study. As indicated on plate 4, mean annual precipitation varies from more than $\mathbf{4 0}$ inches in extreme southeastern Kansas to less than 16 inches in extreme western Kansas. This decrease in precipitation from east to west, in addition to the increase in consumptive water requirements from east to west, should ultimately result in a decline in potential natural recharge from east to west.

Soil properties also affect potential natural recharge in several ways. One of the ways is the rate at which precipitation infiltrates into and out of the soil root zone. The initial amount of precipitation infiltrating into this zone is partially a function of both soil slope and the permeability of the soil surface. Permeability, furthermore, affects how rapidly moisture can move through and out of the soil root zone and beyond the reach of the effects of evapotranspiration. Soil permeability ranges from as little as 0.10 inch per hour for some clayey soils in northeastern Kansas to more than 10 inches per hour in sandy soils in parts of south-central Kansas. Under similar climatic conditions resultant recharge tends to be much greater in very permeable soils than in soils with small permeability.

Another property of the soil that is significant to water use and potential natural recharge is available water capacity. Like permeability, the available water capacity is dependent on soil texture. The available water capacity determines the moisture storage capacity of the soil. It also determines how much water can be held in the soil root zone and is available for consumptive water use. Soils with a silt-loam texture, such as soils formed on loess, tend to have the largest available water capacity (approximately 0.20 inch per inch). Sandy soils tend to have the smallest (less than 0.10 inch per inch). Soils with a large available water capacity and small permeability tend to have smaller consumptive water use, but less overall recharge than sandy soils with small available water capacity and large permeability.

Variations in land use or vegetation are significant to potential natural recharge by affecting the rate of infiltration of precipitation and the consumptive water requirements. Areas of sparse or no vegetative cover, including paved urban areas, tend to result in greater runoff and less infiltration.

More significant than the effect of vegetation on the rate of infiltration is the difference. in consumptive water requirements among the various vegetation types. The differences in consumptive water requirements occur both in total annual needs and seasonal patterns. Consumptive water requirement is expressed as a percentage of PET and is the seasonal pattern of water use by a particular plant if water availability was nonlimiting. Alfalfa, woodlands, and grasslands tend to have the largest consumptive water requirements in Kansas; winter wheat, grain sorghum, and fallow have the smallest. Areas of significant summer fallow, as in the winter-wheat-growing areas of western and central Kansas, tend to have small consumptive water requirements and, therefore, greater potential natural recharge than those lands with different vegetative types.

The potential natural recharge patterns for Kansas shown on plate 4 take into consideration the climatic factors, soils, and vegetation. As is evident, potential mean annual natural recharge declines from as much as 8 inches in extreme southeastern Kansas to less than 0.5 inch in western Kansas. The climatic factors contributing to greater consumptive water use, PET and less precipitation, are obviously most significant. However, more localized variations in potential natural recharge are most likely the result of soil or vegetation factors, or both.

\section{ESTIMATES OF FRESHWATER STORAGE AND POTENTIAL NATURAL RECHARGE}

There is a total of about $590,000,000$ acrefeet of freshwater available in storage in all the principal aquifers in Kansas (table 2). This is about one-third more than previous estimates of 


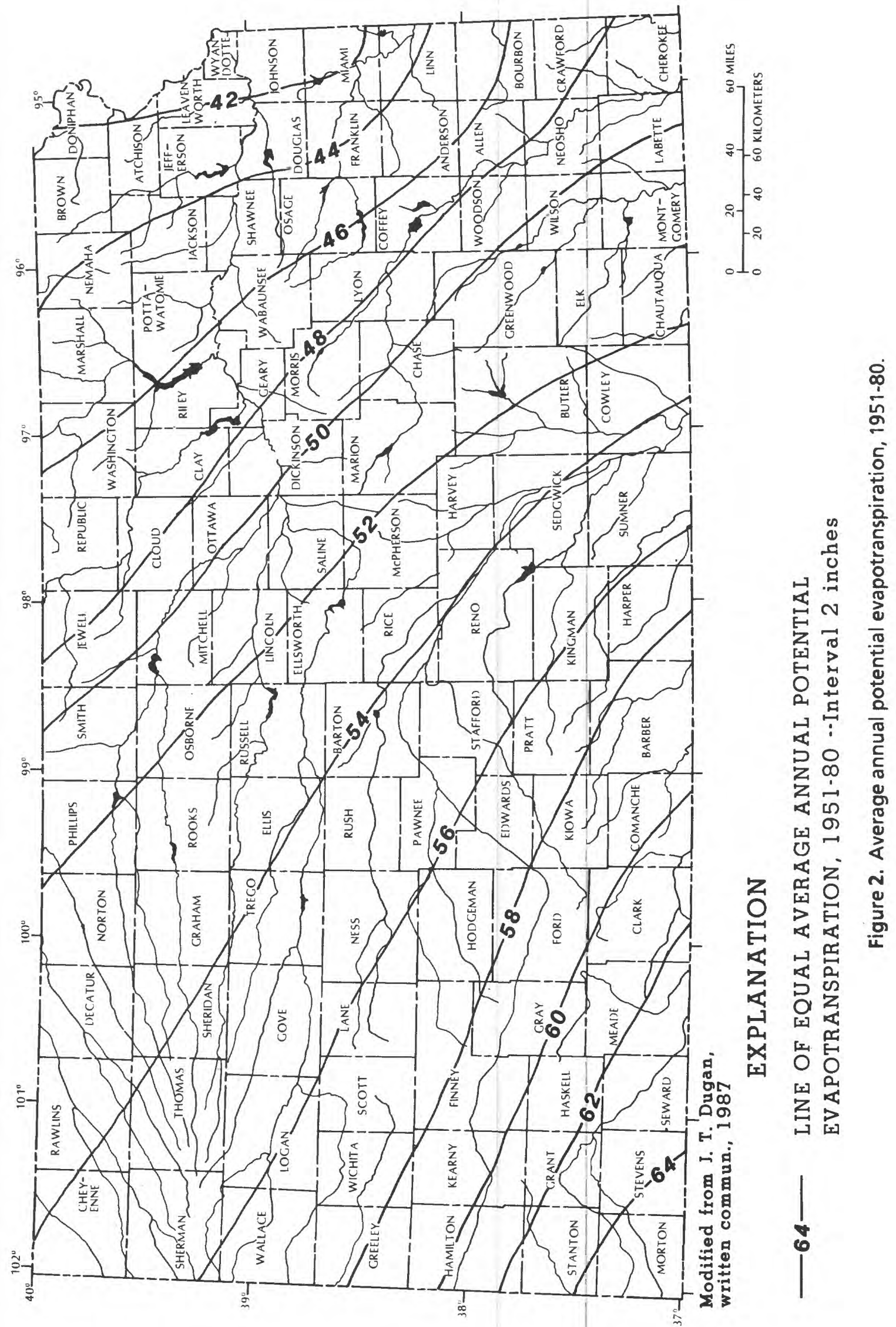




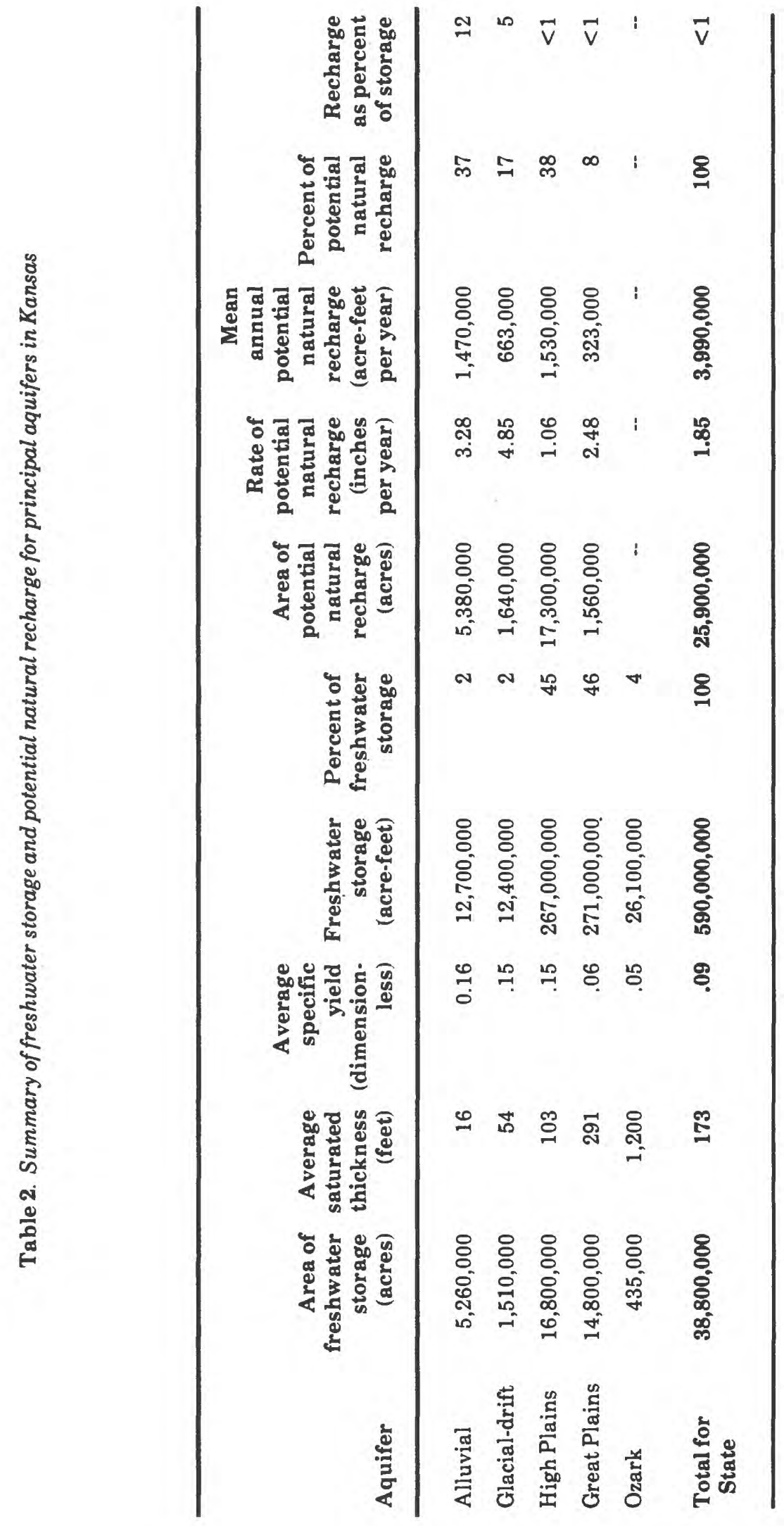


freshwater storage; for example, $425,420,000$ acre-feet by the Kansas Water Resources Board (1967); 456,820,000 acre-feet by Stuart W. Fader (U.S. Geological Survey, written commun., 1974); and $380,000,000$ acre-feet by Hambleton (1984). Most of the difference may be due to differences in estimated saturated thickness and in the considered extent of the aquifers. The aquifers in unconsolidated deposits have about $292,000,000$ acre-feet of freshwater in storage, with most of that in the High Plains aquifer (table 2). The aquifers in consolidated rocks have about 297,000,000 acre-feet of freshwater in storage, about equal to that of aquifers in unconsolidated deposits (table 2). Almost all the freshwater storage in the consolidated rocks is in the Great Plains aquifer system. The areal extent and amount of freshwater storage for all the principal aquifers together and for each aquifer individually are shown in figures 3 through 8. By comparing these figures, one can see that the large volumes of freshwater storage in western and central Kansas are due mainly to large volumes in overlapping areas of the extensive and thick High Plains aquifer and the Great Plains aquifer system (figs. 6 and 7). The large volume of freshwater storage in southeastern Kansas is in the thick Ozark aquifer (fig. 8). The relatively small amount of freshwater storage in much of eastern Kansas (fig. 4) is due to the presence of only the alluvial aquifers, which are neither extensive nor thick.

Hambleton (1984) estimated yearly precipitation in Kansas at about $120,000,000$ acre-feet. Only a small part of this precipitation becomes recharge to aquifers. About $3,990,000$ acre-feet of that precipitation is estimated by this study to be the yearly potential natural recharge to all the principal aquifers in Kansas (table 2). Recharge previously was estimated by the Kansas Water Resources Board (1967) to be $3,335,000$ acre-feet per year. In this study, about $3,660,000$ acre-feet per year is estimated as potential natural recharge to the aquifers in unconsolidated deposits. About 323,000 acre-feet per year is estimated as potential natural recharge to the Great Plains aquifer system. There is no direct natural recharge to the Ozark aquifer because it does not crop out in the State.

The volume of mean annual natural recharge and the extent of the area where potential natural recharge takes place for all the principal aquifers together and for each aquifer individually are shown in figures 9 through 13 . The relatively even distribution of natural recharge across the State, as shown in figure 9B, can be misleading. By comparing figure $9 \mathrm{~A}$ with figure $9 B$, one can see this even distribution is due to limited areas of potential natural recharge, with greater rates of natural recharge in eastern Kansas, and to large areas of natural recharge in the west, with lesser rates of natural recharge. The areas in both western and eastern Kansas with small volumes of mean annual natural recharge are mainly due to small areas of natural recharge, but the lesser rate of natural recharge also is an important factor in western Kansas. The areas with large volumes of mean annual natural recharge are the result of both large areas of natural recharge and relatively greater rates of natural recharge.

Previous estimates of recharge based on precipitation range from 1 percent of precipitation for unirrigated land in western Kansas (Gutentag and others, 1981) to as much as 20 percent in south-central Kansas (Williams and Lohman, 1949), with most estimates being less than 10 percent of precipitation. Dugan and Peckenpaugh (1985) reported that the computer model used to estimate recharge in the area of the CMRASA study gave results similar to past estimates based on precipitation. They reported that recharge ranges from 2 percent of precipitation where precipitation is 15 inches per year to 25 percent of precipitation where precipitation is 40 inches per year.

\section{Alluvial Aquifers}

Freshwater in storage in the alluvial aquifers was estimated to be $12,700,000$ acre-feet (table 2). This is similar to the $10,000,000$ acrefeet estimated by Hambleton (1984) for these same aquifers. Small volumes of freshwater storage in counties in southwestern Kansas (fig. 4B) are due to both the limited extent of the aquifers and their small saturated thicknesses. Sedgwick, County's relatively large volume of freshwater storage occurs in an area where there is a major stream and widespread alluvial deposits (fig. 4A).

Saturated thickness of the alluvial aquifers ranges from near zero, where the deposits are nearly absent or have dissolved-solids 
concentrations greater than $1,000 \mathrm{mg} / \mathrm{L}$, to more than 120 feet in Sedgwick County (plate 1). Saturated thickness averages about 16 feet throughout most of the alluvial aquifers. A set of maps from the Kansas Water Resources Board (1967) was the primary source of information on the saturated thickness of the alluvial aquifers. The boundaries of the alluvial aquifers were modified to better fit the limits of the alluvial deposits as shown on the State geologic map (Kansas Geological Survey, 1964). In parts of northeastern Kansas, saturated thickness was calculated from water-level measurements from the U.S. Geological Survey's Ground Water Site Inventory data base and a map of depth to bedrock by Bayne (1975). In the Neosho, Verdigris, Walnut, and Lower Arkansas River basins, the saturated thickness was modified by data from Morton and Fader (1975) and Fader and Morton (1975a and 1975b). In the Arkansas River valley in Hamilton and Kearny Counties, saturated thickness was based on data from Barker and others (1983). The areas with dissolved-solids concentrations greater than $1,000 \mathrm{mg} / \mathrm{L}$ in the alluvial aquifers were determined from water-quality data in the U.S. Geological Survey's Water Data Storage and Retrieval System (WATSTORE) water-quality file. In some parts of the alluvial aquifers the water quality decreases with depth, especially where these aquifers are directly underlain by Permian or Lower Cretaceous rocks (Fader, 1968; Gogel, 1981). Not enough information is known about the occurrence of this poorer quality water in the alluvial aquifers to exclude those parts of the aquifers that contain water with dissolved-solids concentrations greater than $1,000 \mathrm{mg} / \mathrm{L}$ at depth from the estimates of saturated thickness and freshwater storage made in this study.

Specific yield of the alluvial aquifers ranges from 0.1 to 0.2 and averages 0.16 (plate 3 ). A map of specific yield by Bayne and Ward (1969) was used extensively for estimating specific yield of the alluvial aquifers and updated with more recent data where available. A specific yield of 0.15 was chosen for the alluvial aquifers in the Kansas River valley based on an average value from Fader (1974). Specific yield was estimated to be $\mathbf{0 . 1 5}$ for the alluvial aquifers in the Neosho, Verdigris, and Walnut River valleys and part of the Arkansas River valley based on values from Morton and Fader (1975) and Fader and Morton (1975a and 1975b). Specific yields of 0.15 and 0.2 were used for the alluvial deposits from the Arkansas River valley in Hamilton and Kearny Counties (plate 3 ) based on values from Barker and others (1983).

The mean annual rate of potential natural recharge to the alluvial aquifers ranges from less than 0.5 inch per year in western Kansas to slightly more than 8 inches per year in extreme southeastern Kansas (plate 4) and averages 3.28 inches per year. The volume of potential natural recharge to the alluvial aquifers was estimated to be $1,470,000$ acre-feet per year, or about 12 percent of freshwater storage (table 2). Small amounts of potential natural recharge in counties in western and parts of eastern Kansas (fig. 10B) are due to limited areas of natural recharge (fig. $10 \mathrm{~A}$ ); the smaller rate of natural recharge also is an important factor in western Kansas (plate 4).

\section{Glacial-Drift Aquifers}

The $12,400,000$ acre-feet of freshwater (table 2) estimated by this study to be in storage in the glacial-drift aquifers is close to Hambleton's (1984) estimate of $20,000,000$ acre-feet. Large volumes of freshwater storage in Marshall, Nemaha, and Atchison Counties (fig. 5B) are due mainly to the relatively large thicknesses of glacial deposits in buried valleys (plate 1).

Saturated thickness of the glacial-drift aquifers ranges from near zero, where they are nearly absent or have dissolved-solids concentrations greater than $1,000 \mathrm{mg} / \mathrm{L}$, to more than 320 feet in Nemaha County (plate 1) and averages 54 feet. In northeastern Kansas where glacial deposits are widespread, well information from the Kansas Geological Survey (Lawrence, Kansas), saturated-thickness maps from Ward $(1973 ; 1974)$, and the location of preglacial drainage from Denne and others (1982) were used to define the saturated thickness and location of the glacial-drift aquifers. Maps from the Kansas Water Resources Board (1967) and the location of glacial deposits from the State geologic map (Kansas Geologic Survey, 1964) also were used to define the saturated thickness and areal extent in other areas, especially west of Nemaha County. The areas with dissolvedsolids concentrations greater than $1,000 \mathrm{mg} / \mathrm{L}$ in the glacial-drift aquifers were determined from 


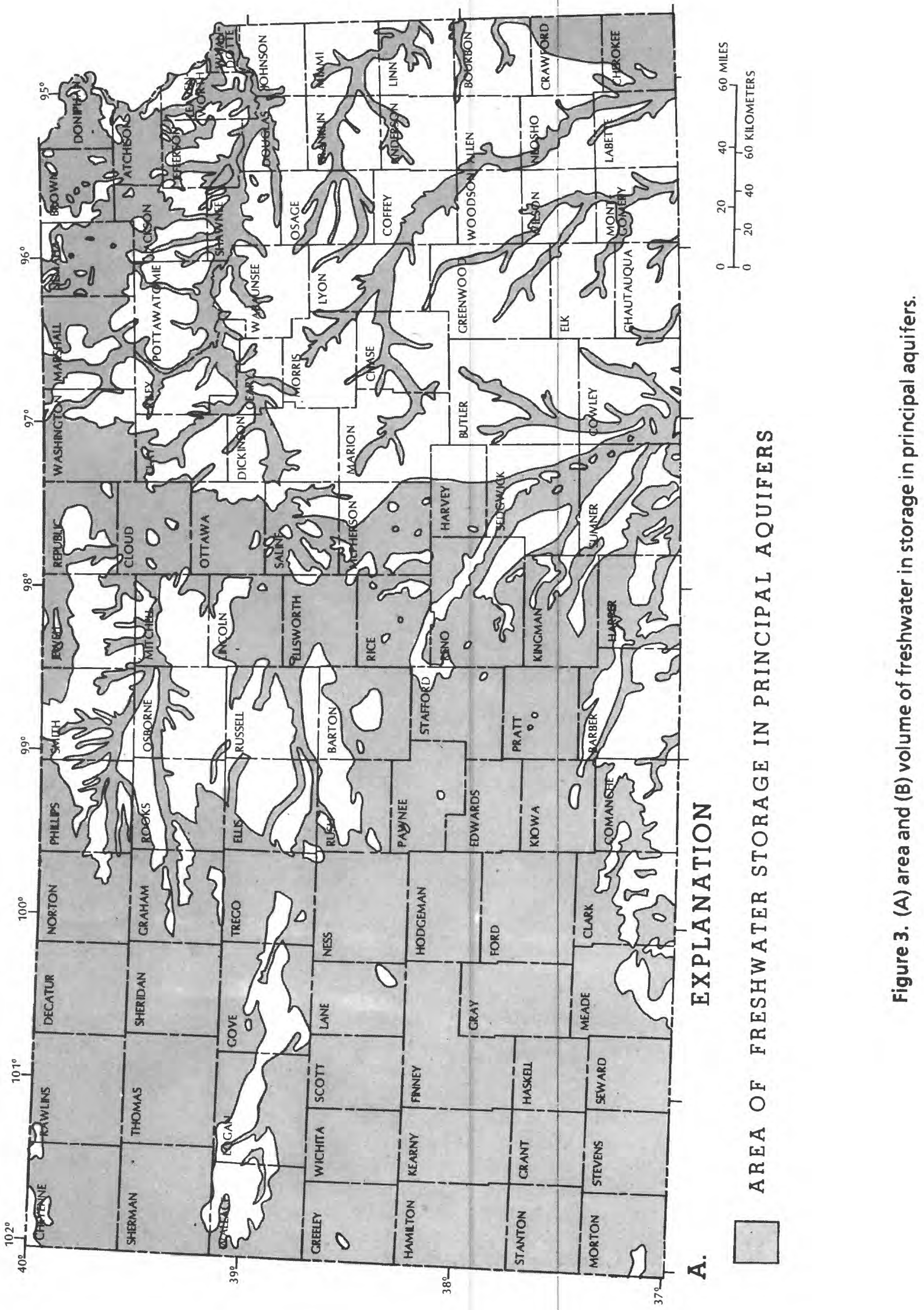




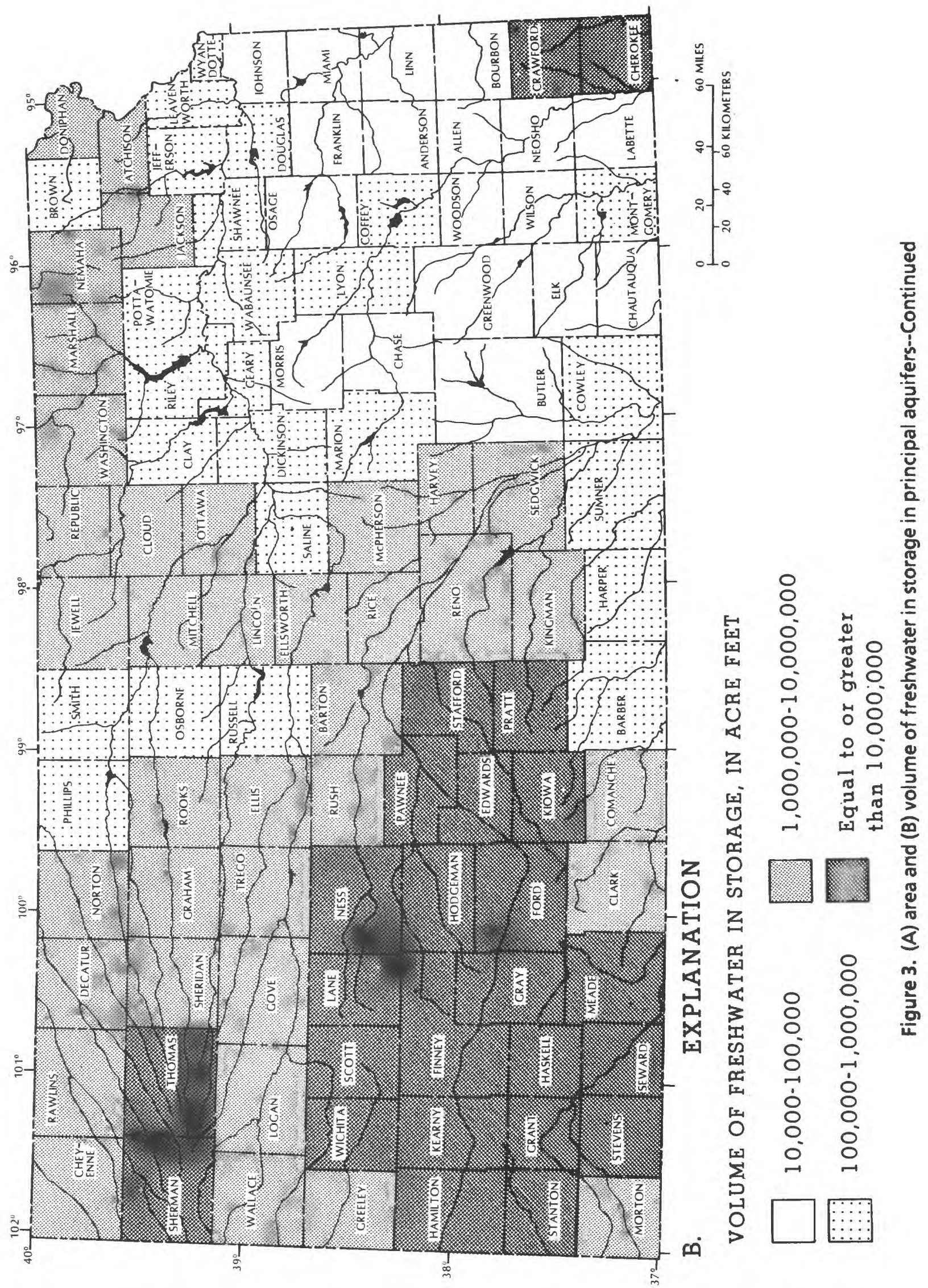









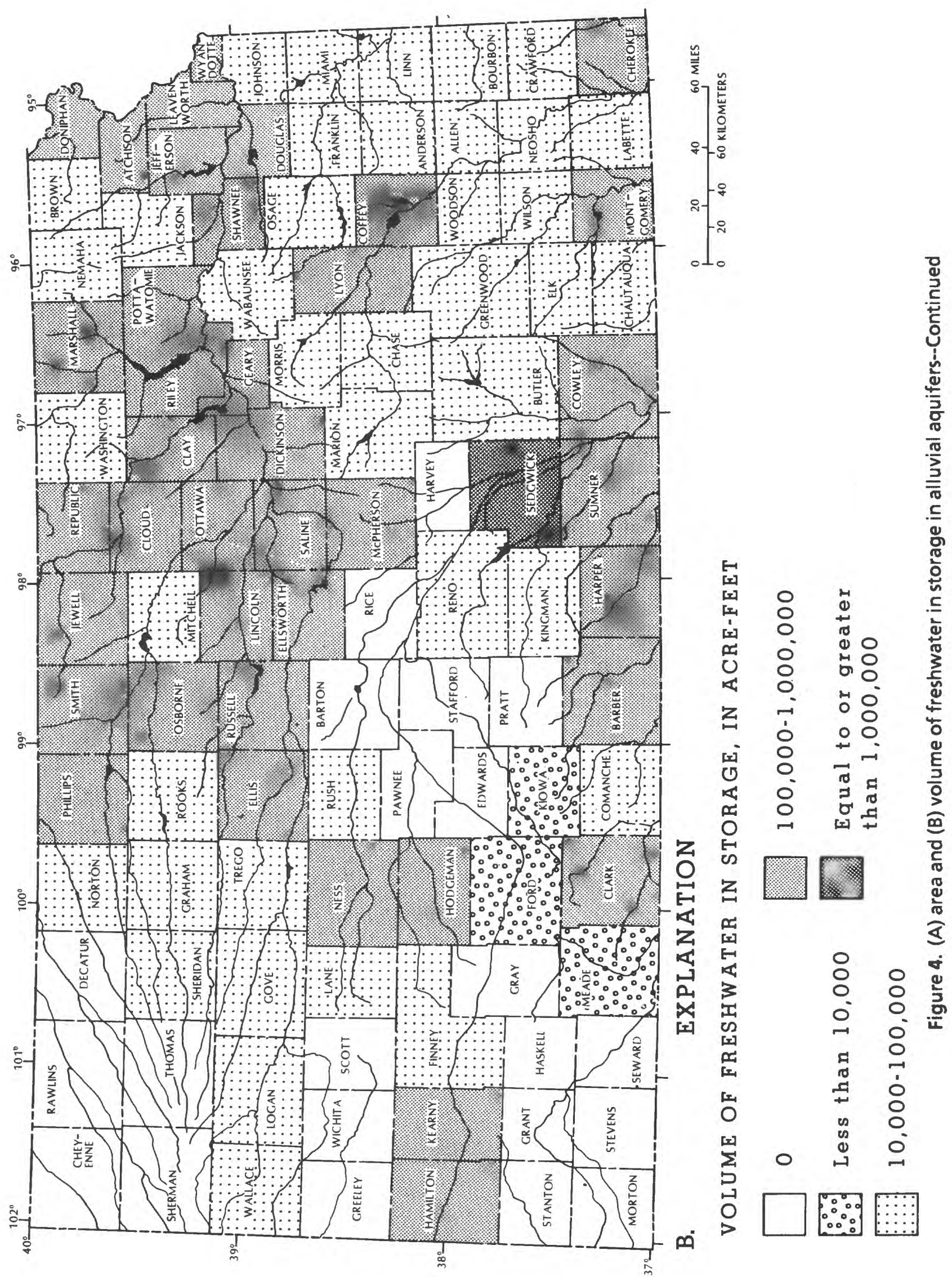




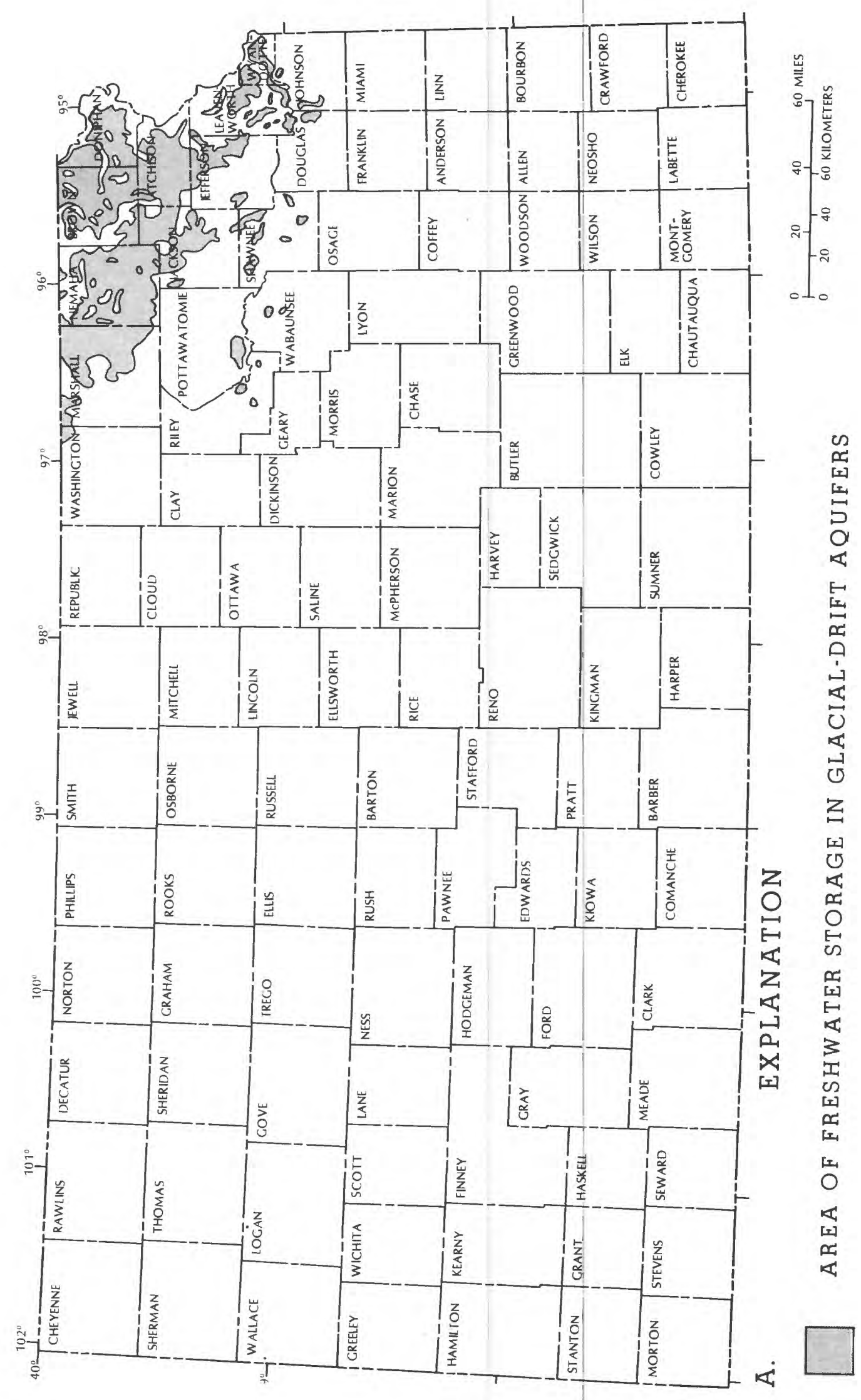

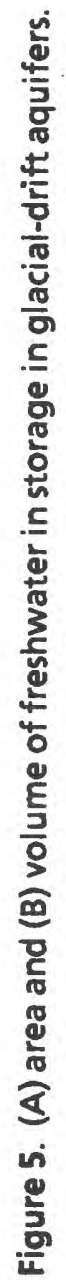




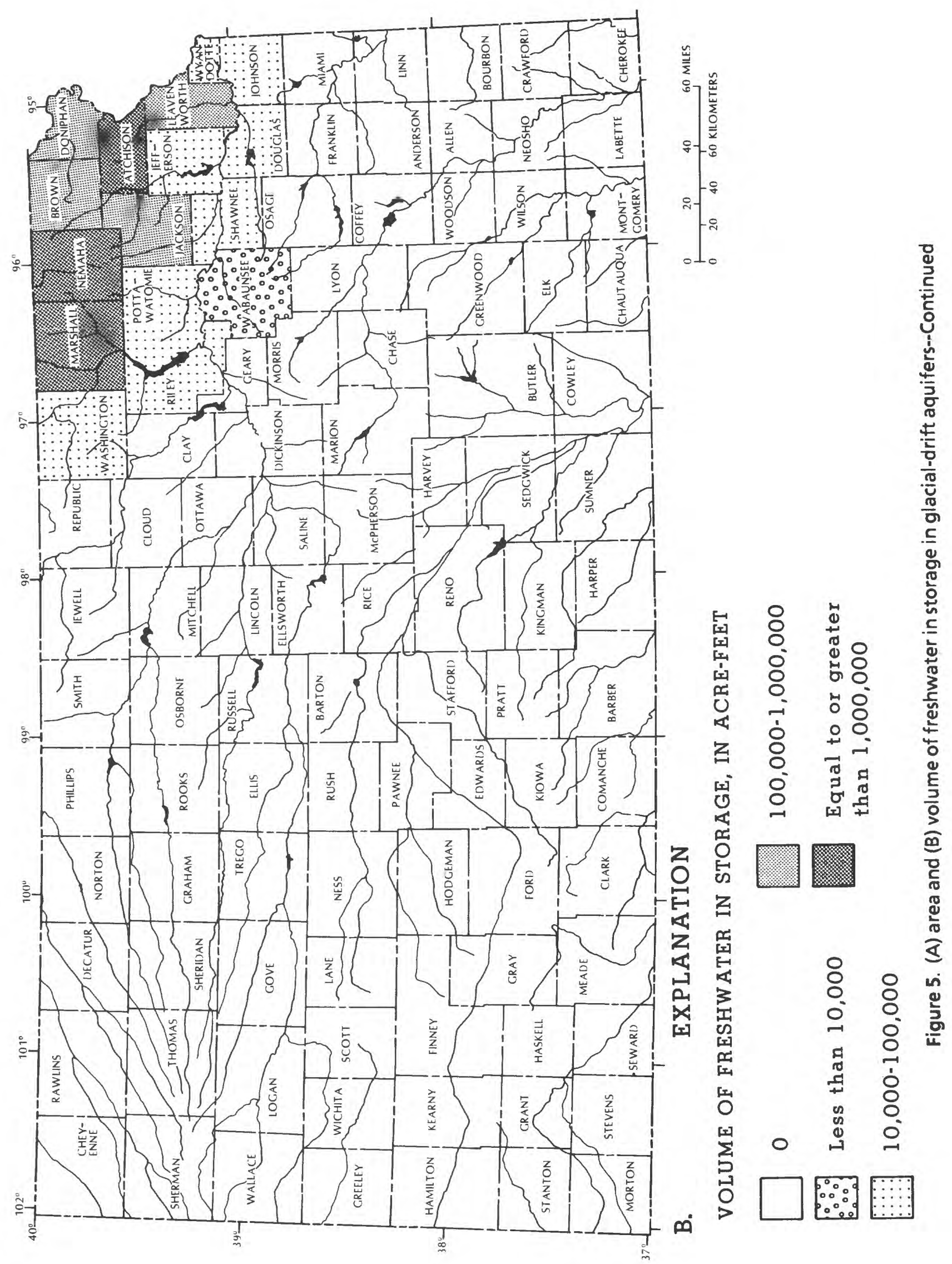




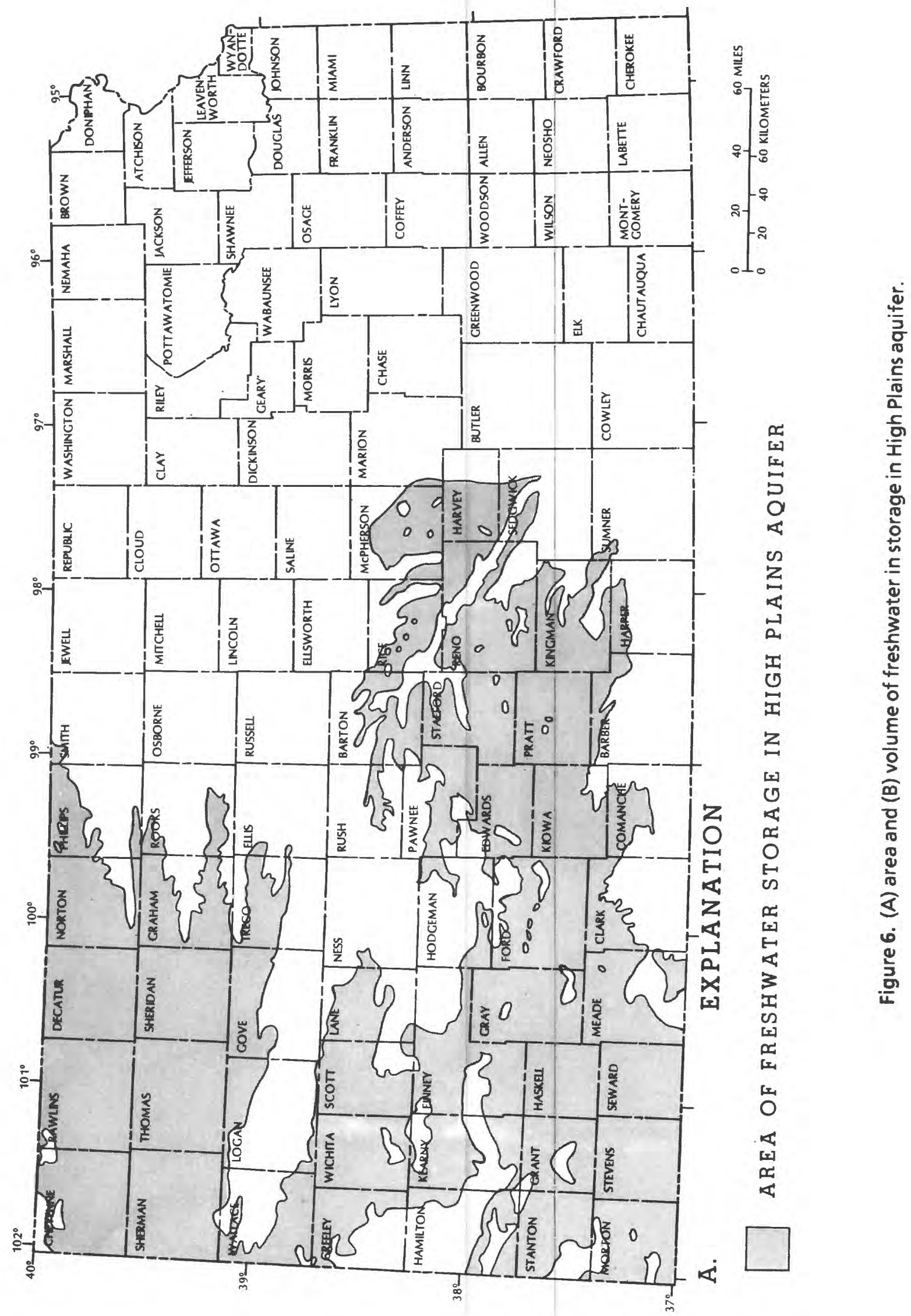




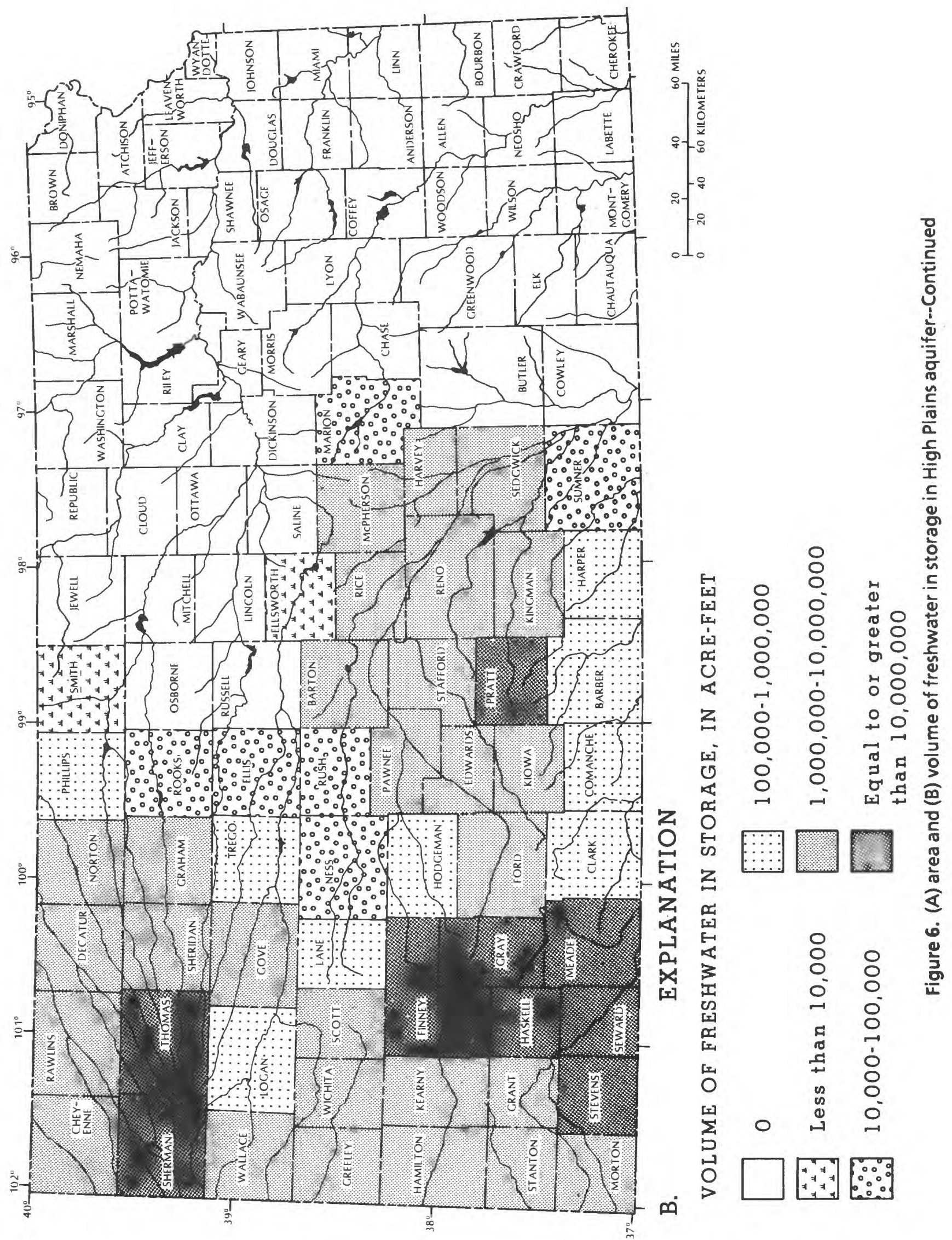




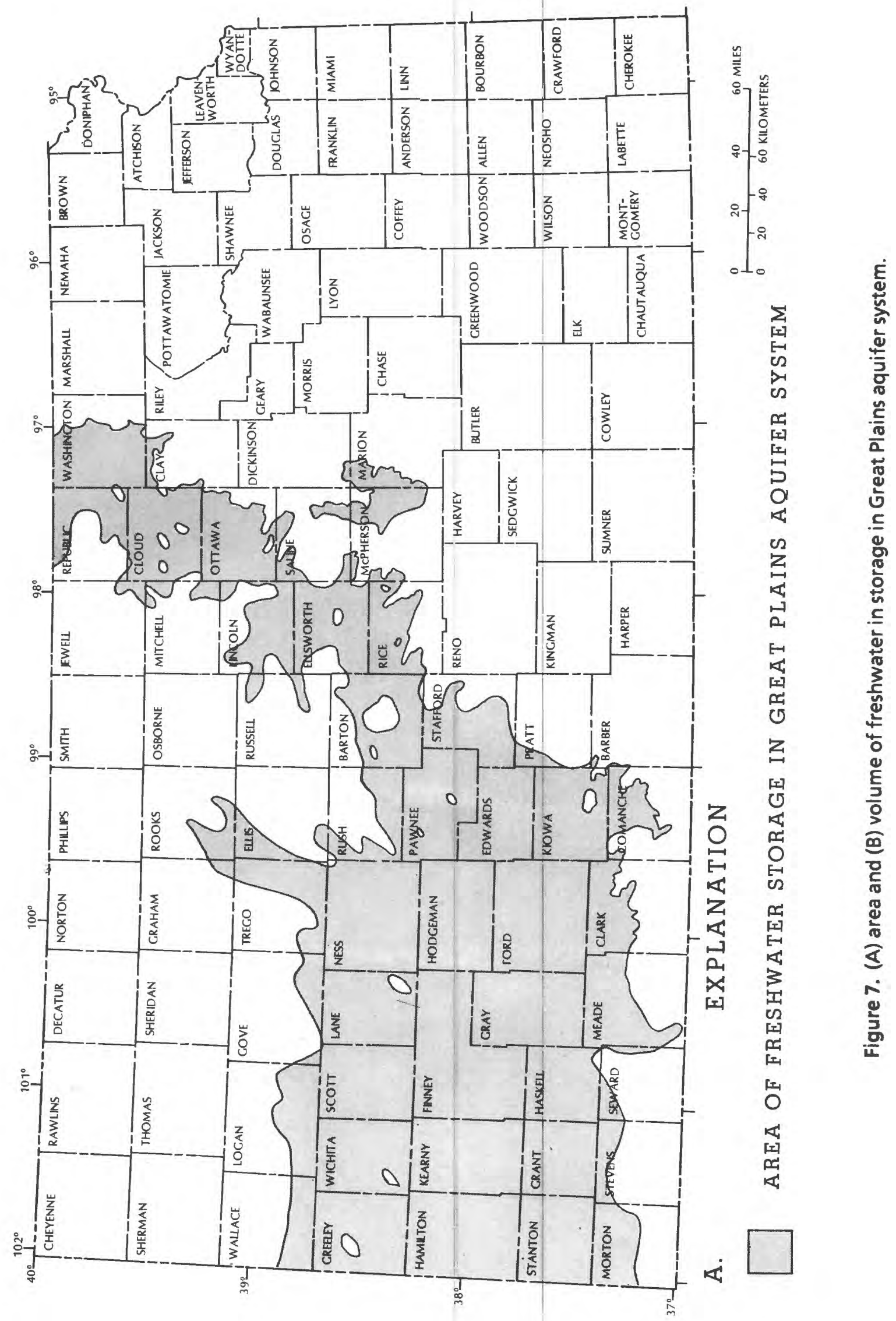




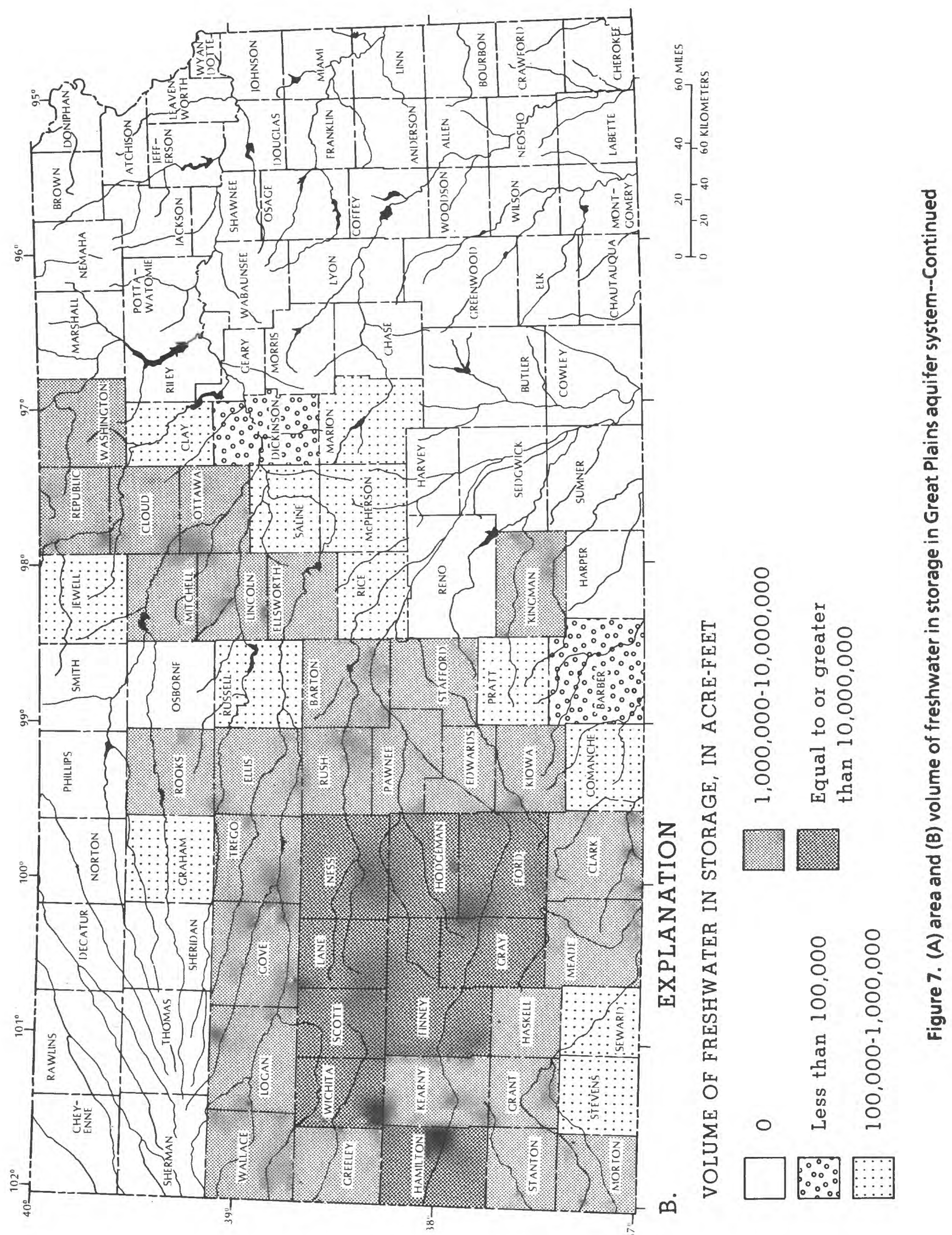




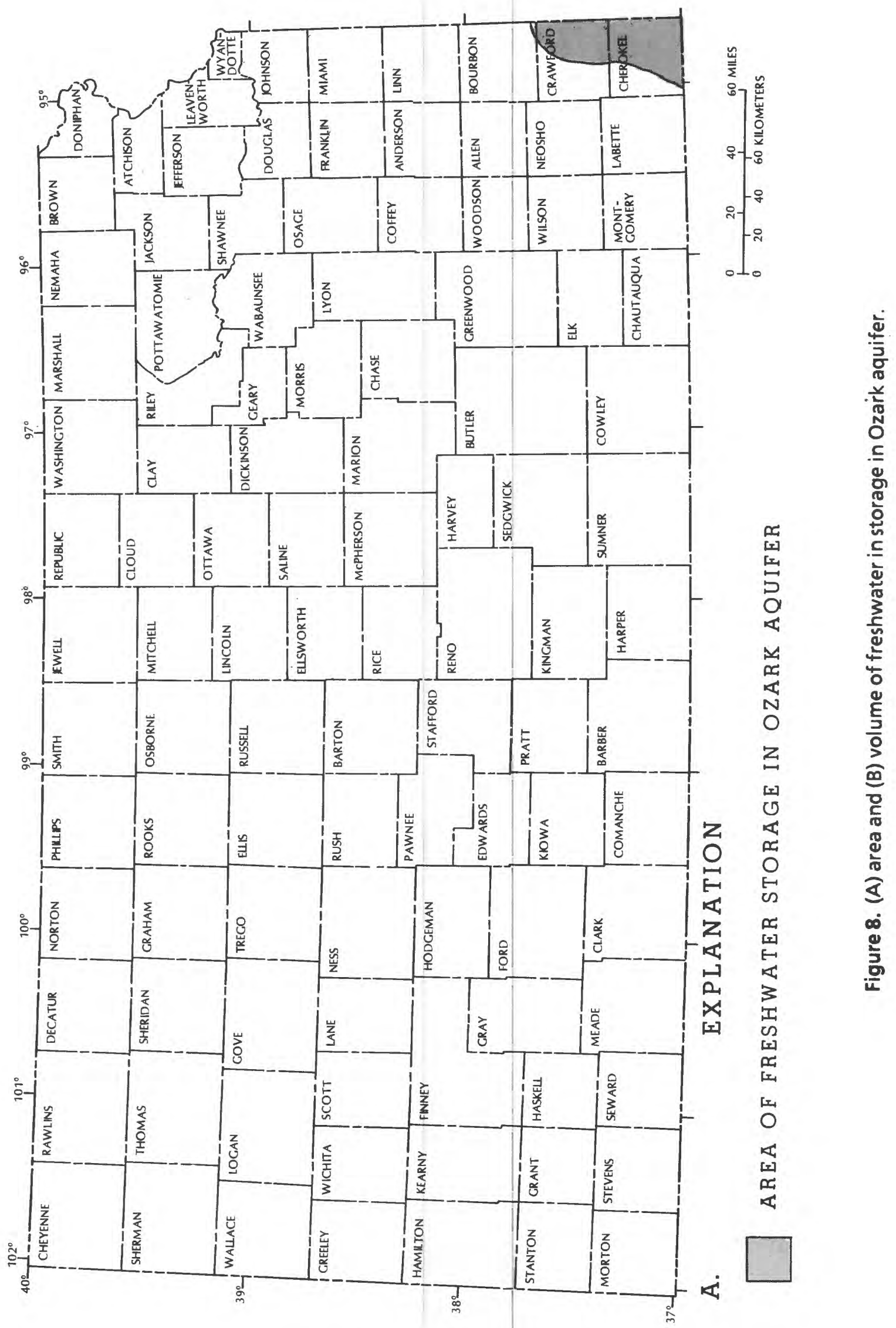




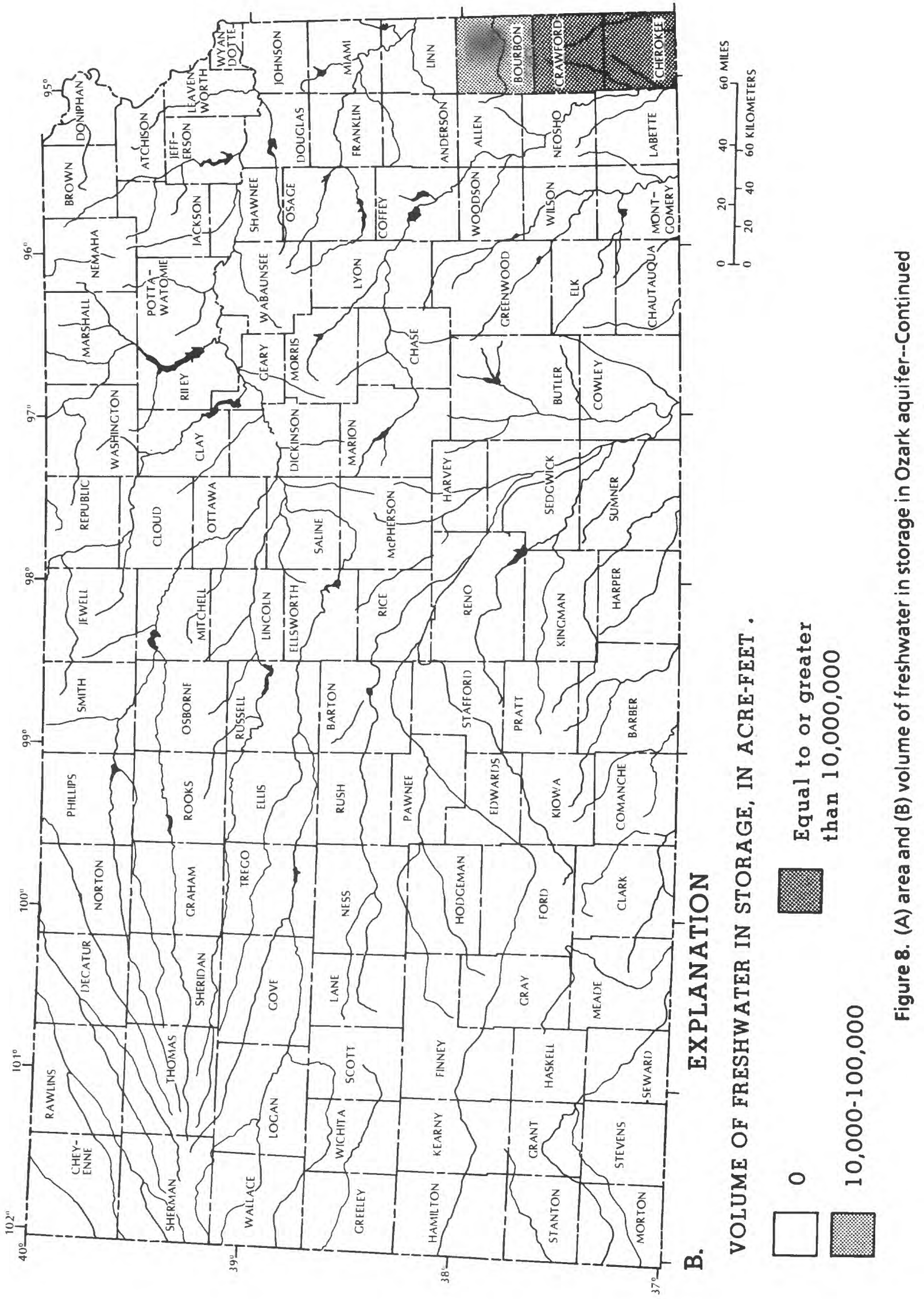




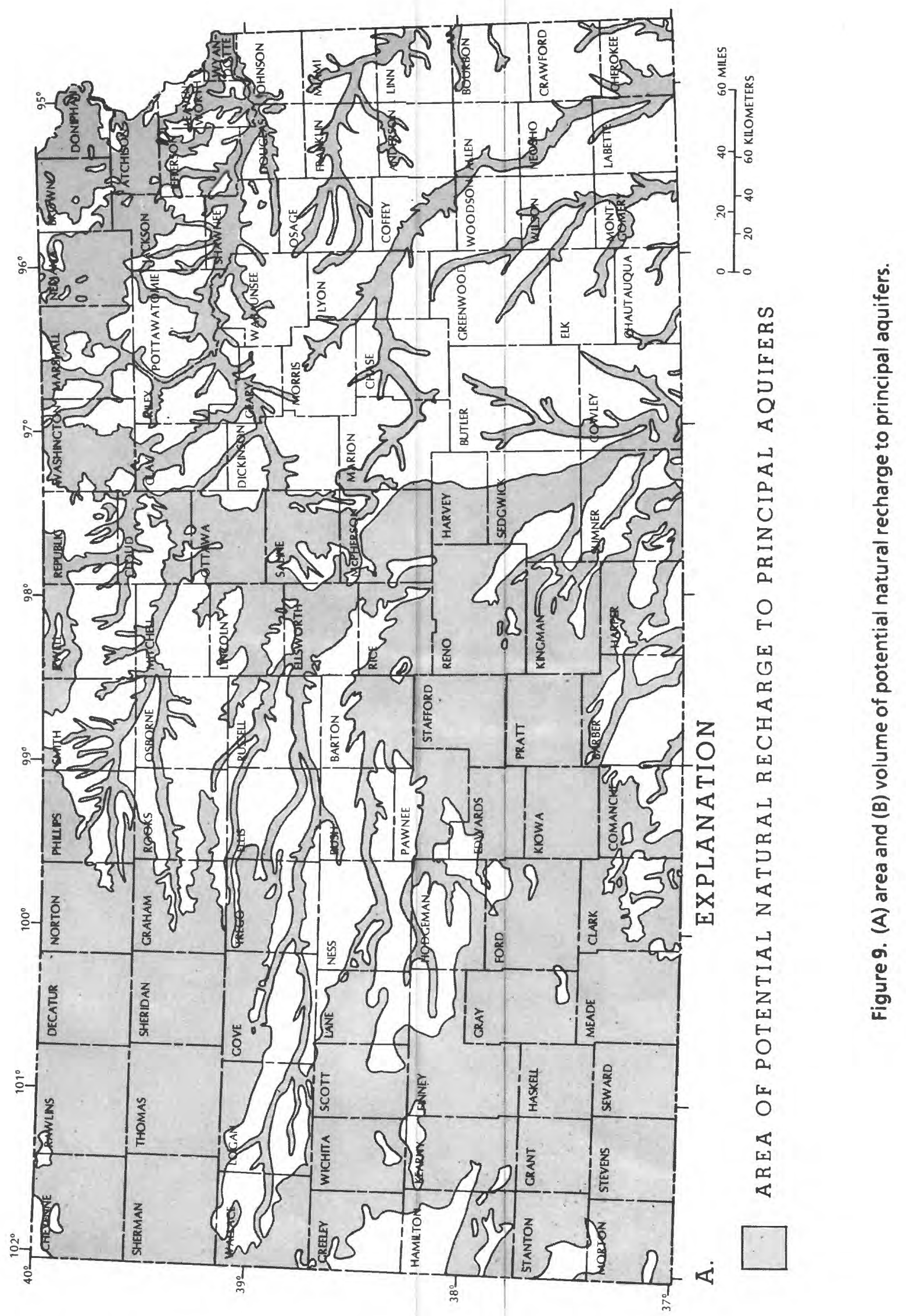




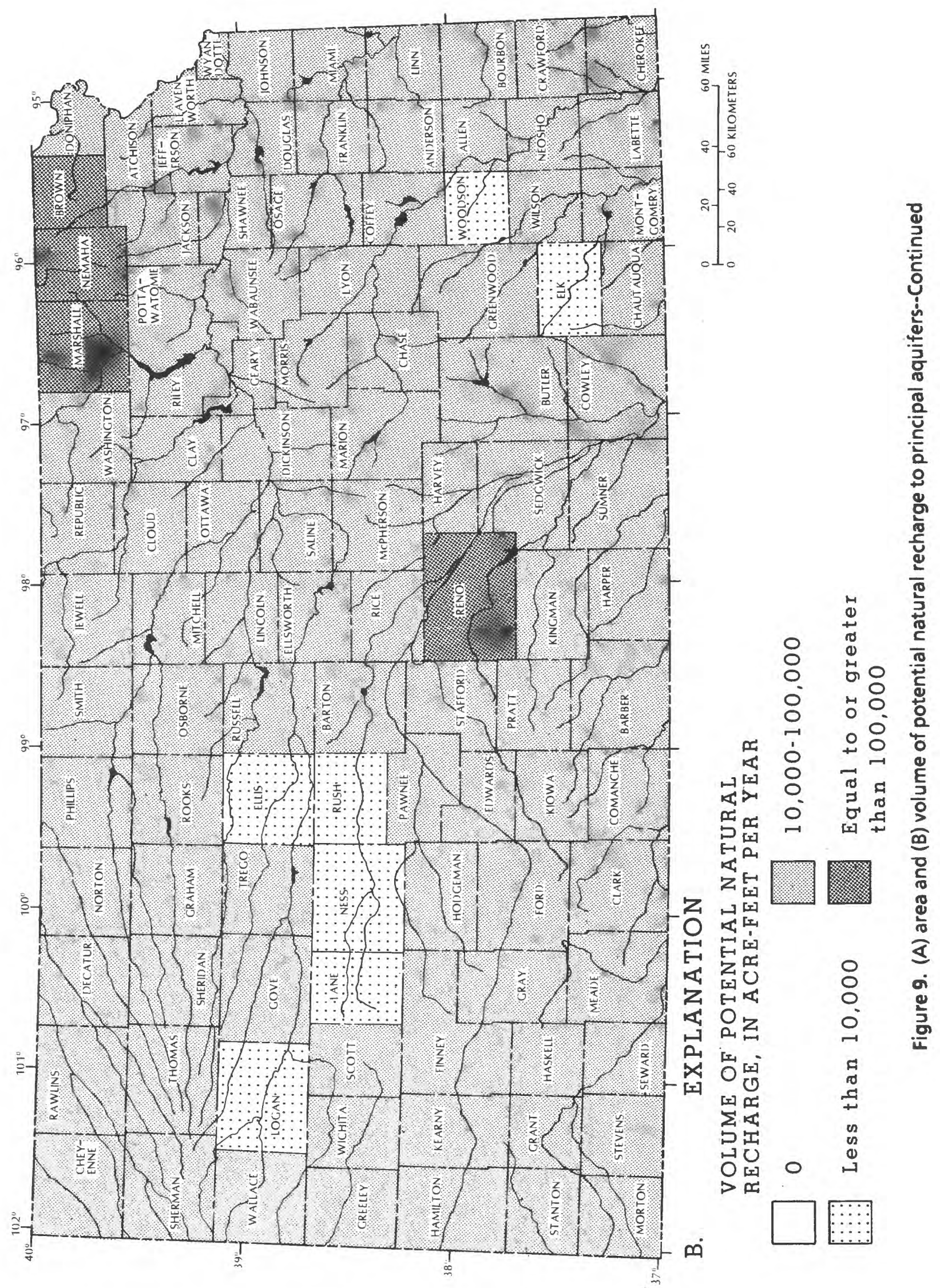




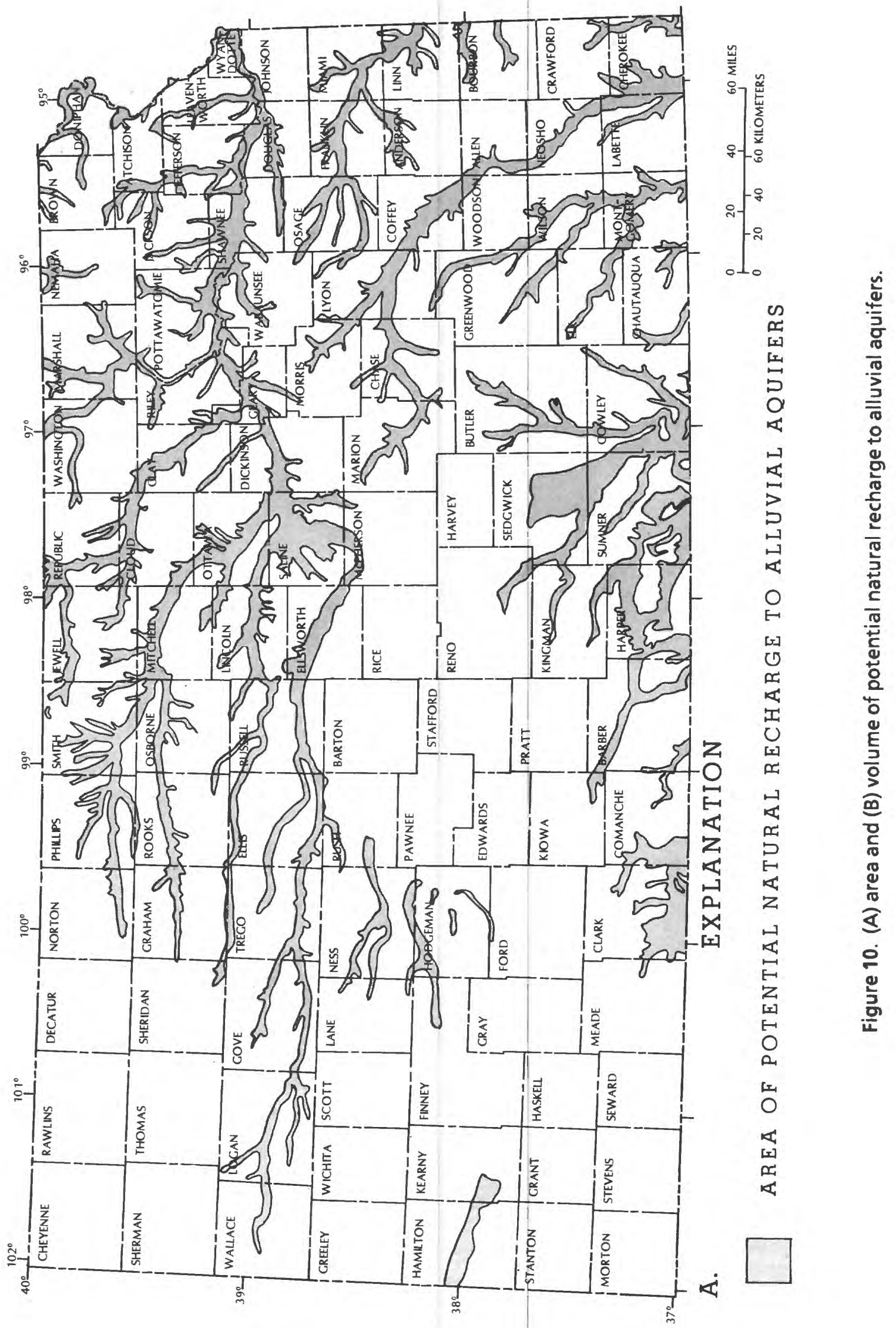




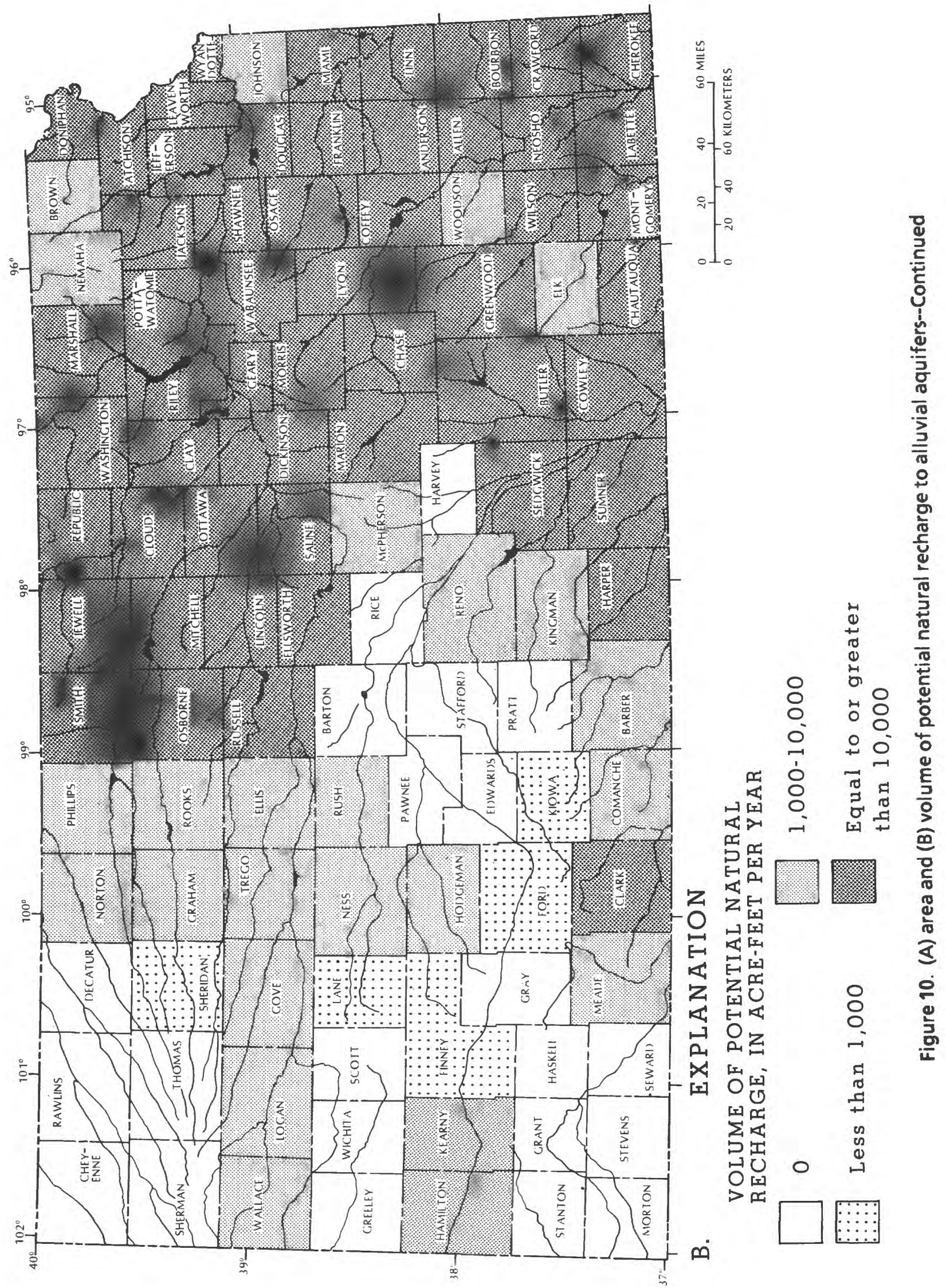




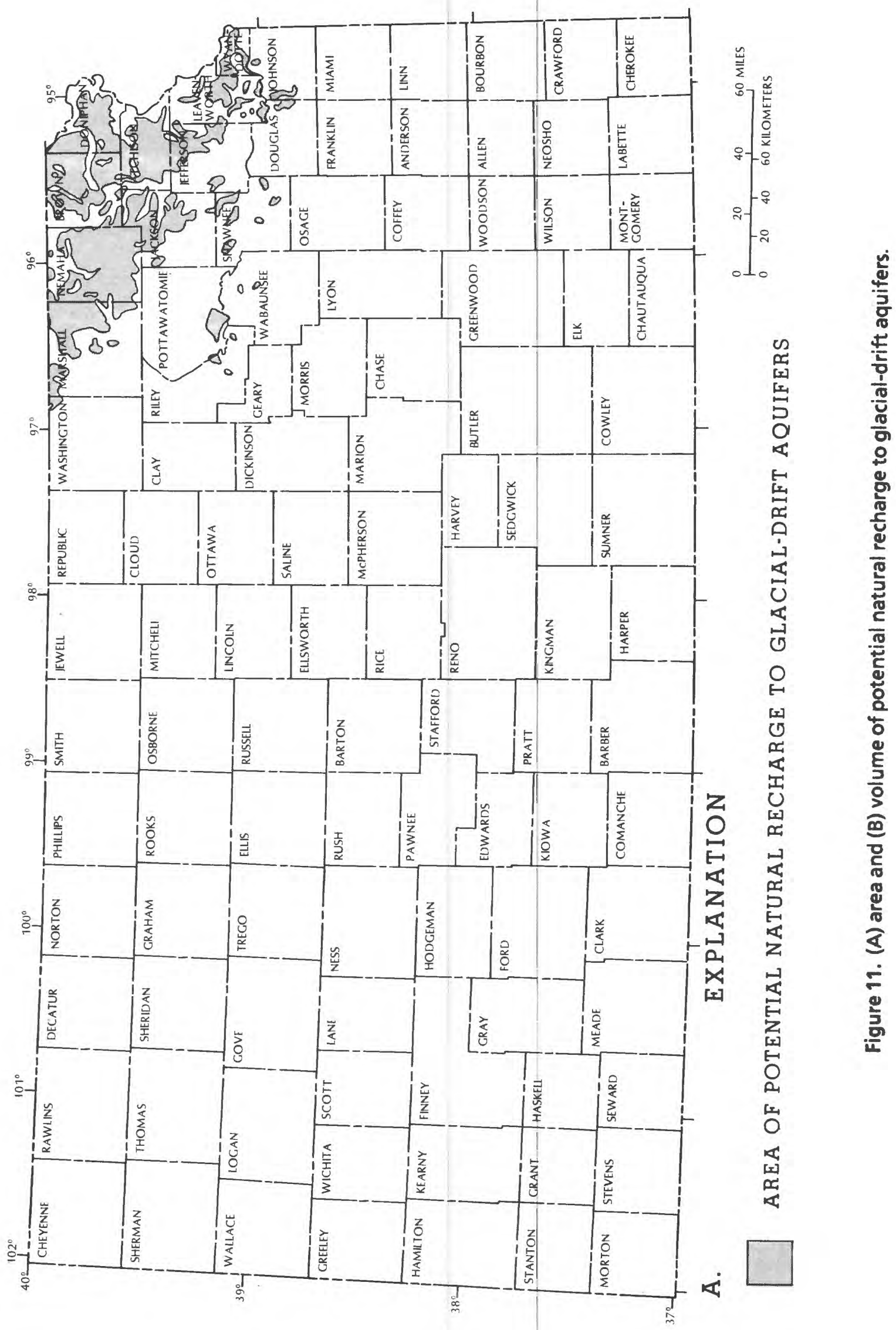




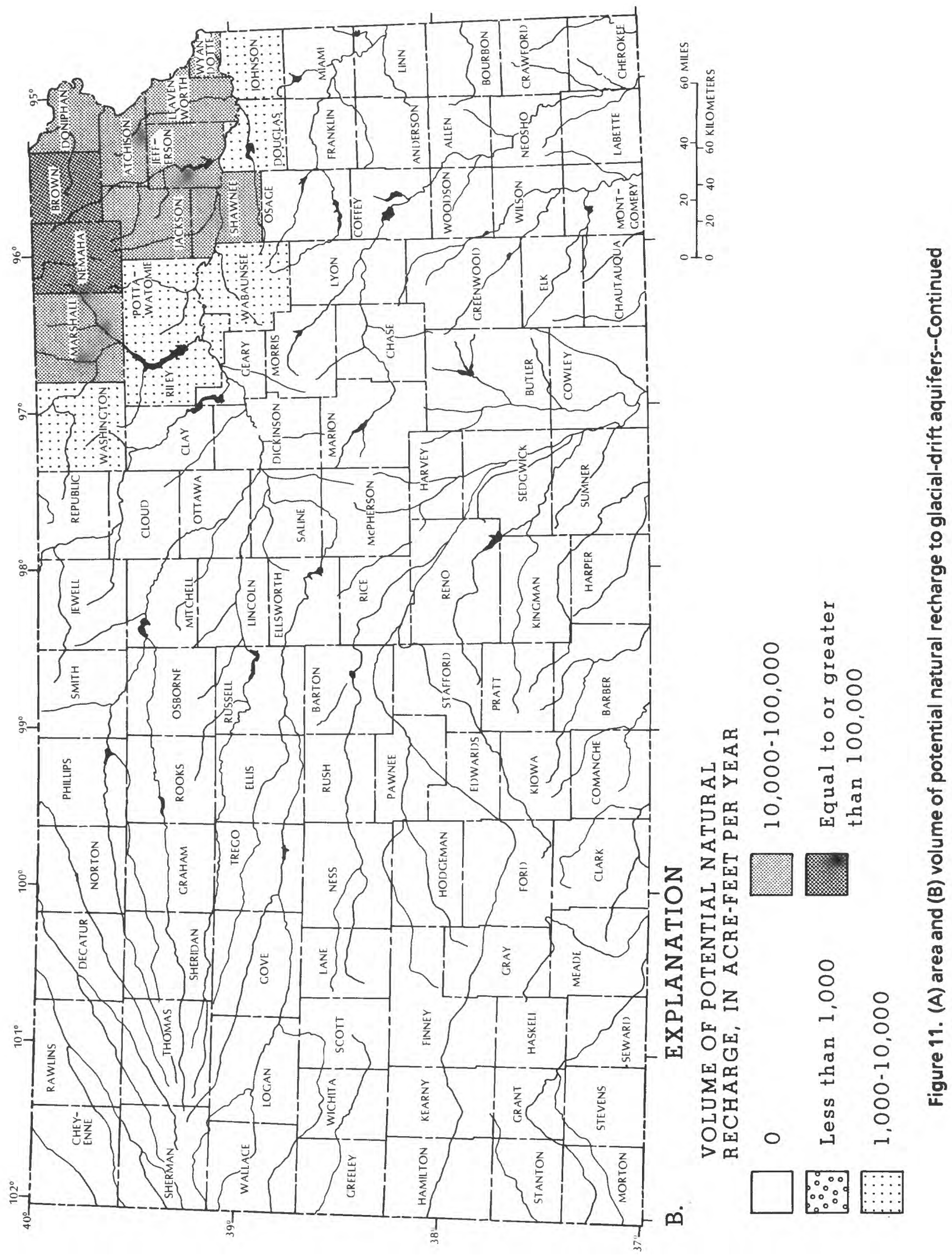




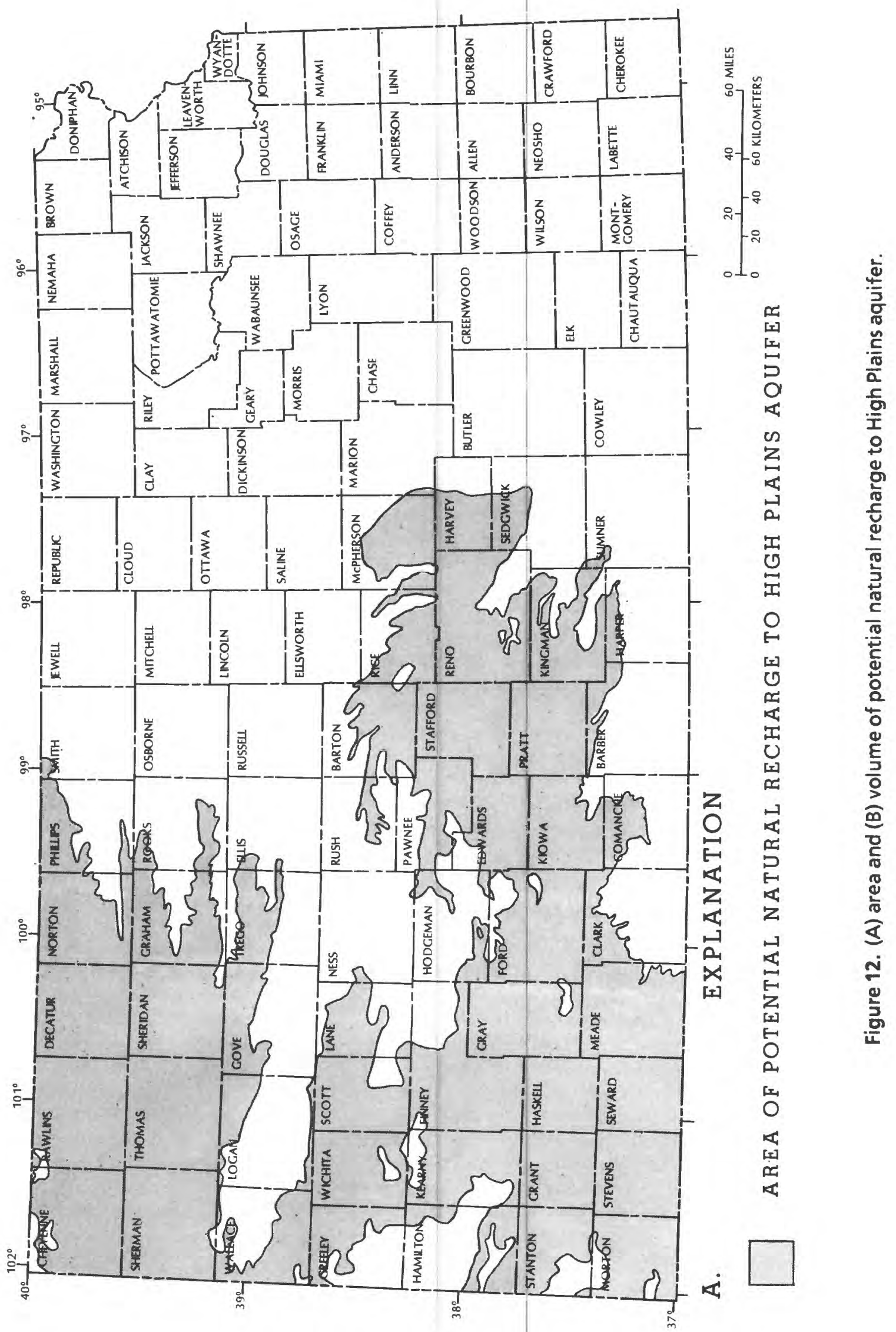




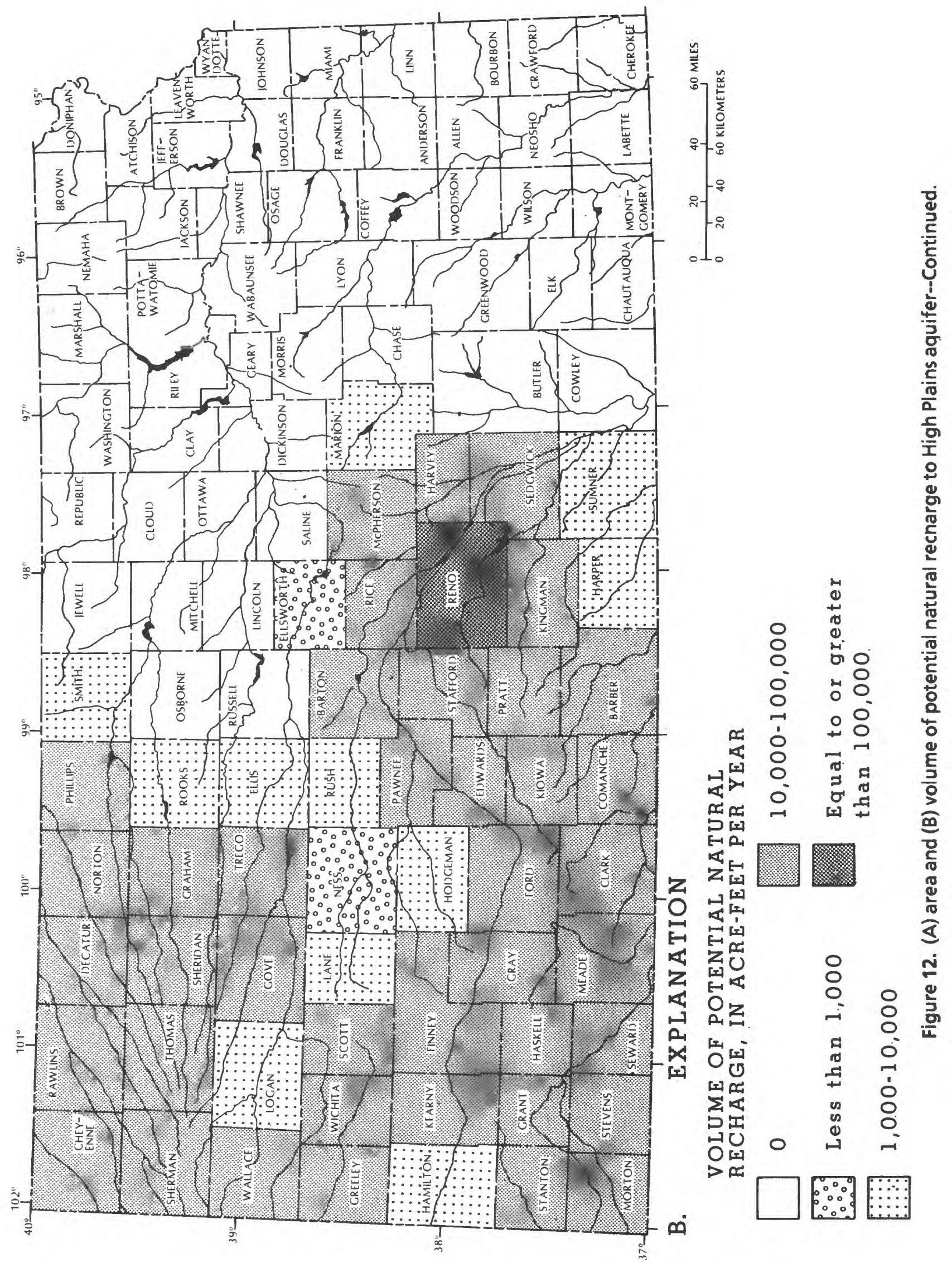




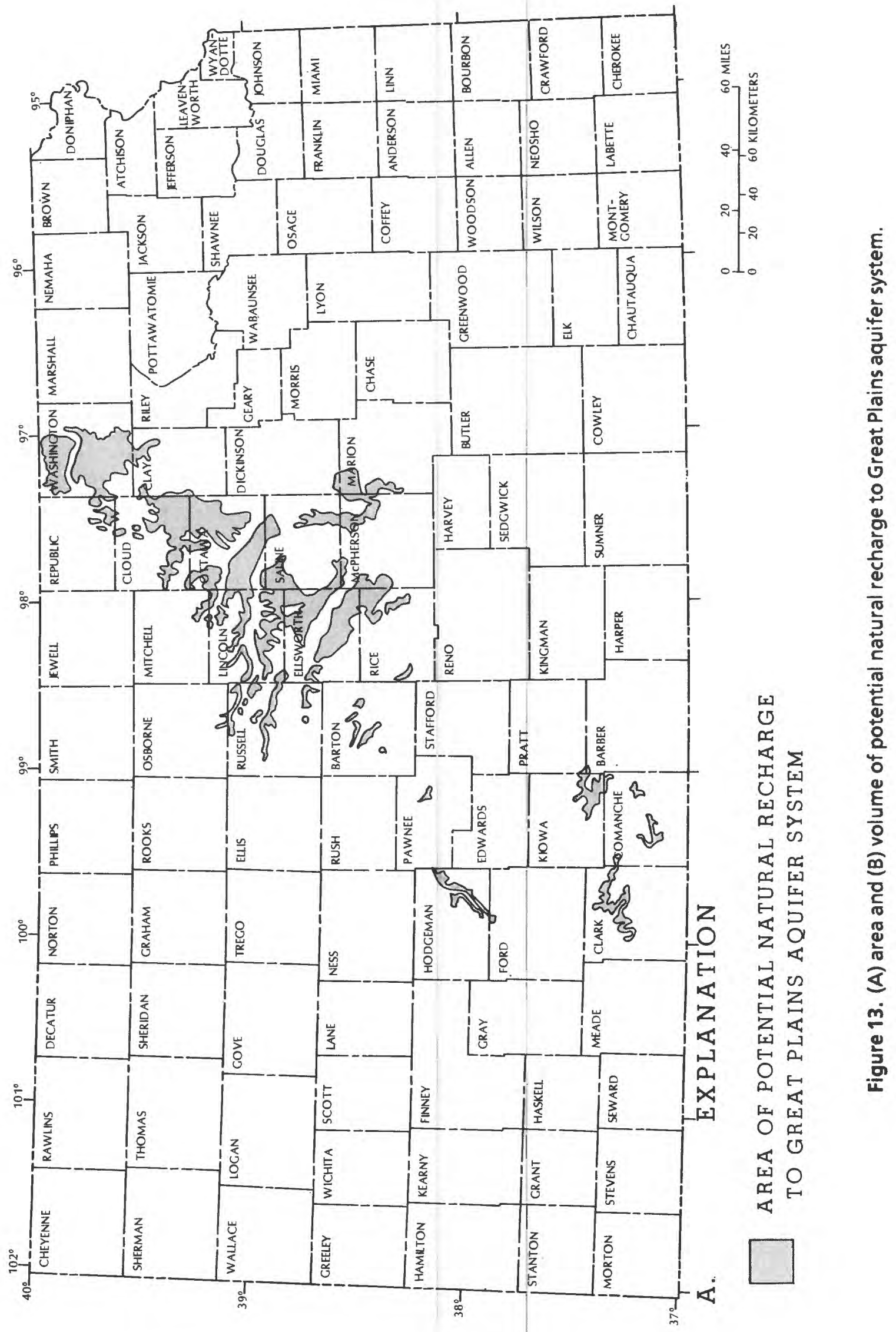




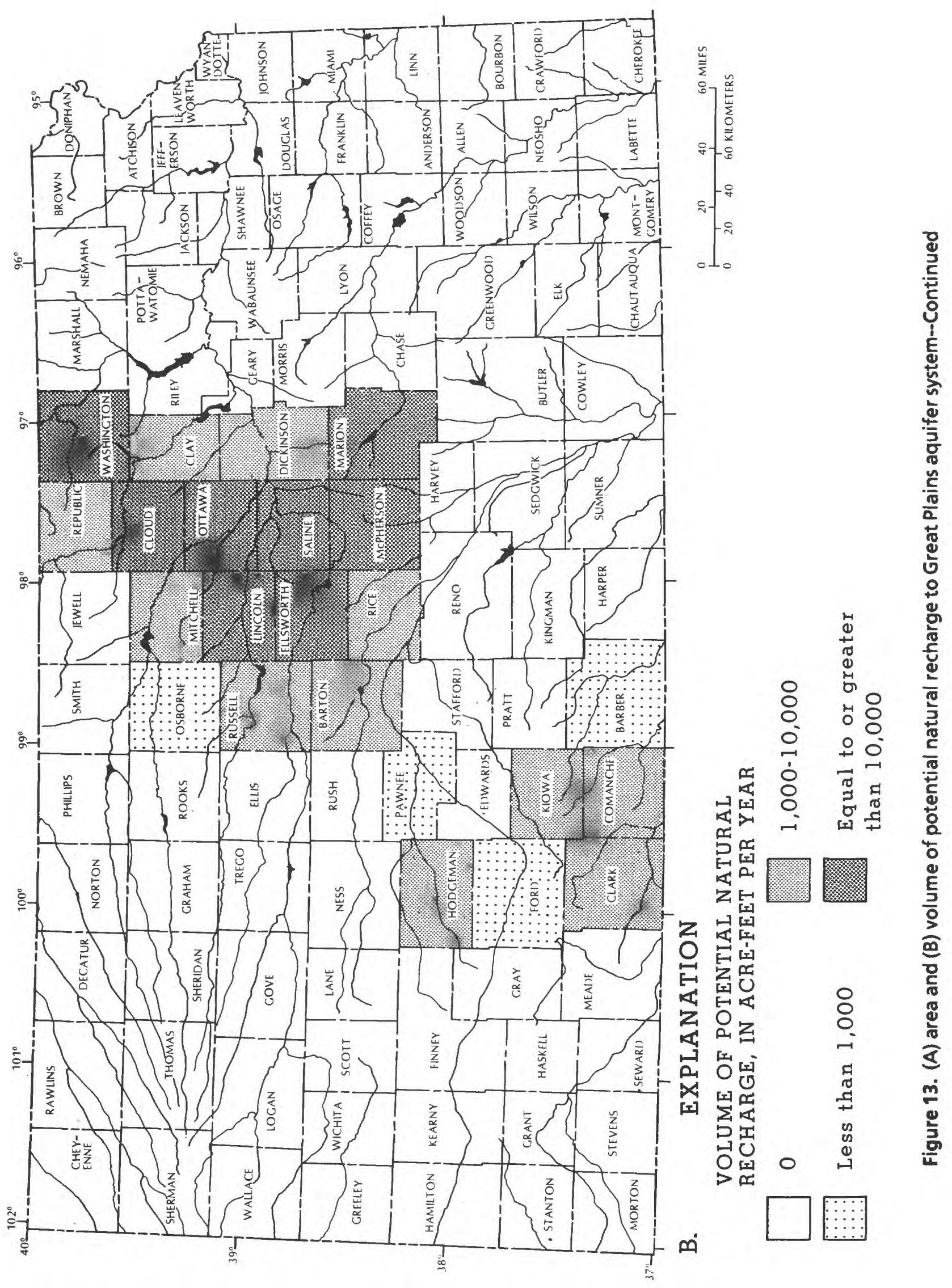


water-quality data on file with the U.S. Geological Survey (Lawrence, Kansas). In the deeply buried parts of the glacial-drift aquifers the water quality decreases with depth (Ward, 1974). Not enough information is known about the occurrence of this poorer quality water in the glacial-drift aquifers to exclude those parts of the aquifers that contain water with dissolved-solids concentrations greater than $1,000 \mathrm{mg} / \mathrm{L}$ at depth from the estimates of saturated thickness and freshwater storage made in this study.

In northeastern Kansas, a specific yield of 0.15 was chosen for all glacial deposits (plate 3 ) based on aquifer tests reported in Reed and Burnett (1985). The mean annual rate of potential natural recharge to the glacial-drift aquifers ranges from about 3 inches per year in Riley County to more than 6 inches per year in Douglas and Johnson Counties (plate 4) and averages 4.85 inches per year. The volume of potential natural recharge to these aquifers was estimated to be 663,000 acre-feet per year, or about 5 percent of freshwater storage (table 2). Large amounts of natural recharge to the glacialdrift aquifers in Nemaha and Brown Counties (fig. 11B) are due in part to large areas of glacial deposits.

\section{High Plains Aquifer}

Freshwater in storage in the High Plains aquifer was estimated by this study to be $267,000,000$ acre-feet (table 2). This is almost the same as the estimate of $271,000,000$ acre-feet of freshwater storage made by Hambleton (1984). Large volumes of freshwater storage in Finney, Gray, Haskell, Meade, Pratt, Seward, Sherman, Stevens, and Thomas Counties (fig. 6B) are due to large saturated thicknesses in those counties (plate 1).

Saturated thickness of the High Plains aquifer ranges from near zero, where the aquifer is nearly absent or has dissolved-solids concentrations greater than $1,000 \mathrm{mg} / \mathrm{L}$, to more than 560 feet in Seward County (plate 1) and averages about 103 feet. For most of the area of the High Plains aquifer, the saturated thickness was estimated from maps of the configuration of the base of the High Plains aquifer (Watts and Stullken, 1981) and the altitude of the water table in the High Plains aquifer for 1980 (Pabst and Stullken, 1984). Data from the U.S.
Geological Survey's Ground Water Site Inventory file were used to update and modify the 1980 water-table map. Saturated thickness in part of the Pawnee River valley was based on data from Sophocleous (1980). In western Meade and northern Clark Counties where recent water-level measurements are lacking, the saturated-thickness data from the Kansas Water Resources Board (1967) were used. The areas in the High Plains aquifer with dissolved-solids concentrations greater than $1,000 \mathrm{mg} / \mathrm{L}$ were determined from the WATSTORE water-quality file and from maps by Hathaway and others $(1975 ; 1977 ; 1978 ; 1979 ; 1981)$. In parts of the High Plains aquifer the water quality decreases with depth, especially where it is directly. underlain by Permian rocks or has been contaminated by oilfield brines (Hathaway, Carr, Flanagan, Galle, Waugh, Dickey, and Magnuson, 1978; Hathaway, Galle, Waugh, and Dickey, 1978; Hathaway and others, 1981; Leonard and Kleinschmidt, 1976; Krothe and others, 1982). Not enough is known about the occurrence of this poorer quality water in the High Plains aquifer to exclude those parts of the aquifer that contain water with dissolved-solids concentrations greater than $1,000 \mathrm{mg} / \mathrm{L}$ at depth from the estimates of saturated thickness and freshwater storage made in this study.

Specific yield of the High Plains aquifer ranges from 0.05 to 0.2 and averages 0.15 (plate 3 ). Areas within the High Plains aquifer were assigned specific-yield values of $0.05,0.15$, and 0.2 based on a map by Stullken and others (1985) showing areas with three ranges of specific yield $(0-0.1,0.1-0.2$, and $0.2-0.25)$ for the High Plains aquifer.

The mean annual rate of potential natural recharge to the High Plains aquifer ranges from less than 0.5 inch per year in western Kansas to more than 3 inches per year in south-central Kansas (plate 4) and averages 1.06 inches per year. This is more than twice the rate of natural recharge estimated for western Kansas by Stullken and others (1985) from a water-balance model. The rates of recharge from Stullken and others (1985) may be too small because actual water-level declines in western Kansas have not been as great as predicted using the rates estimated by the water-balance model (L.E. Stullken, U.S. Geological Survey, oral commun., 1986). The volume of potential natural recharge 
to the High Plains aquifer was estimated for this study to be 1,530,000 acre-feet per year, or less than 1 percent of freshwater storage (table 2). The small volumes of natural recharge in some counties (fig. 12B) are due to the limited areas available for natural recharge (fig. 12A). Reno County has a relatively large volume of natural recharge (fig. 12B) because of the large area available for natural recharge and a greater rate of recharge (plate 4).

\section{Great Plains Aquifer System}

Freshwater in storage in the Great Plains aquifer system was estimated to be $271,000,000$ acre-feet (table 2). This is several times larger than the 75,000,000 acre-feet of potable water in storage in the Dakota Formation estimated by Hambleton (1984). The large volumes of freshwater storage in counties in western Kansas (fig. 7B) are due to the great thickness of the Great Plains aquifer system in this area (plate 2).

Saturated thickness of the Great Plains aquifer system ranges from near zero, where the aquifer is nearly absent or has dissolved-solids concentrations greater than $1,000 \mathrm{mg} / \mathrm{L}$, to more than 800 feet in Lane County (plate 2) and averages 291 feet. Saturated thickness of the Great Plains aquifer system was assumed to be the same as the thickness of the rocks that contain the aquifer, except in the area where a map of water-level altitudes and freshwater equivalent heads indicated that the water table was below the top of these rocks. In this area the saturated thickness was estimated by reducing the rock thickness by the amount the water table was below the top of these rocks. Saturated thickness of the Great Plains aquifer system was determined from unpublished maps on file with the U.S. Geological Survey (Lawrence, Kansas). For the Great Plains aquifer system, a chemicalquality map by Keene and Bayne (1977) was used to delineate the areas with more than 1,000 $\mathrm{mg} / \mathrm{L}$ dissolved solids. In parts of the Great Plains aquifer system the water quality decreases with depth, especially where it is directly underlain by Permian rocks (Keene and Bayne, 1977; H.E. McGovern, U.S. Geological Survey, written commun., 1987). Not enough is known about the occurrence of this poorer quality water in the Great Plains aquifer system to exclude those parts of the aquifer that contain water with dissolved-solids concentrations greater than $1,000 \mathrm{mg} / \mathrm{L}$ at depth from the estimates of saturated thickness and freshwater storage made in this study.

Specific yield of the Great Plains aquifer system has been estimated as 0.1 in the Cimarron River basin (U.S. Geological Survey, 1966) and between 0.03 and 0.2 by Keene and Bayne (1977). From the values estimated for the Cimarron Basin (0.1) and by Keene and Bayne (1977) for the unconfined part of the aquifer $(0.15$ to 0.2 ), an average value of 0.15 was chosen by this study for the specific yield of the sandstone in the Great Plains aquifer system. Not all of the Great Plains aquifer system is made up of sandstone; rather it includes large amounts of relatively impermeable materials (siltstone and shale). A map of percent sandstone was made, based on a map of sandstone thickness in Lower Cretaceous rocks (Keene and Bayne, 1977), and the thickness map of the Great Plains aquifer system (plate 2). Three zones were identified on the map and assigned average values of 100-, 66-, and 33-percent sandstone, respectively. The percentage of sandstone in each zone was multiplied by the average specific yield of the sandstone in the Great Plains aquifer system $(0.15)$ to arrive at a specific yield that would be representative of the entire thickness of the Great Plains aquifer system in each zone. These zones (fig. 14) show that specific yield of the Great Plains aquifer system ranges from 0.05 to 0.15 and averages 0.06 . These results correspond well with previous estimates, even the average of 0.06 corresponds well with Keene and Bayne's (1977) estimate of 0.03 to 0.05 for the confined part of the aquifer.

The mean annual rate of potential natural recharge to the Great Plains aquifer system ranges from less than 1 inch per year in western Kansas to about 4 inches per year in northcentral Kansas (plate 4) and averages about 2.48 inches a year. The volume of potential natural recharge to the Great Plains aquifer system was estimated to be 323,000 acre-feet per year, or less than 1 percent of freshwater storage (table 2). Counties in central and north-central Kansas have larger amounts of natural recharge (fig. 13B) because of a combination of greater rates of potential natural recharge and larger areas of natural recharge than found in other counties (plate 4). 


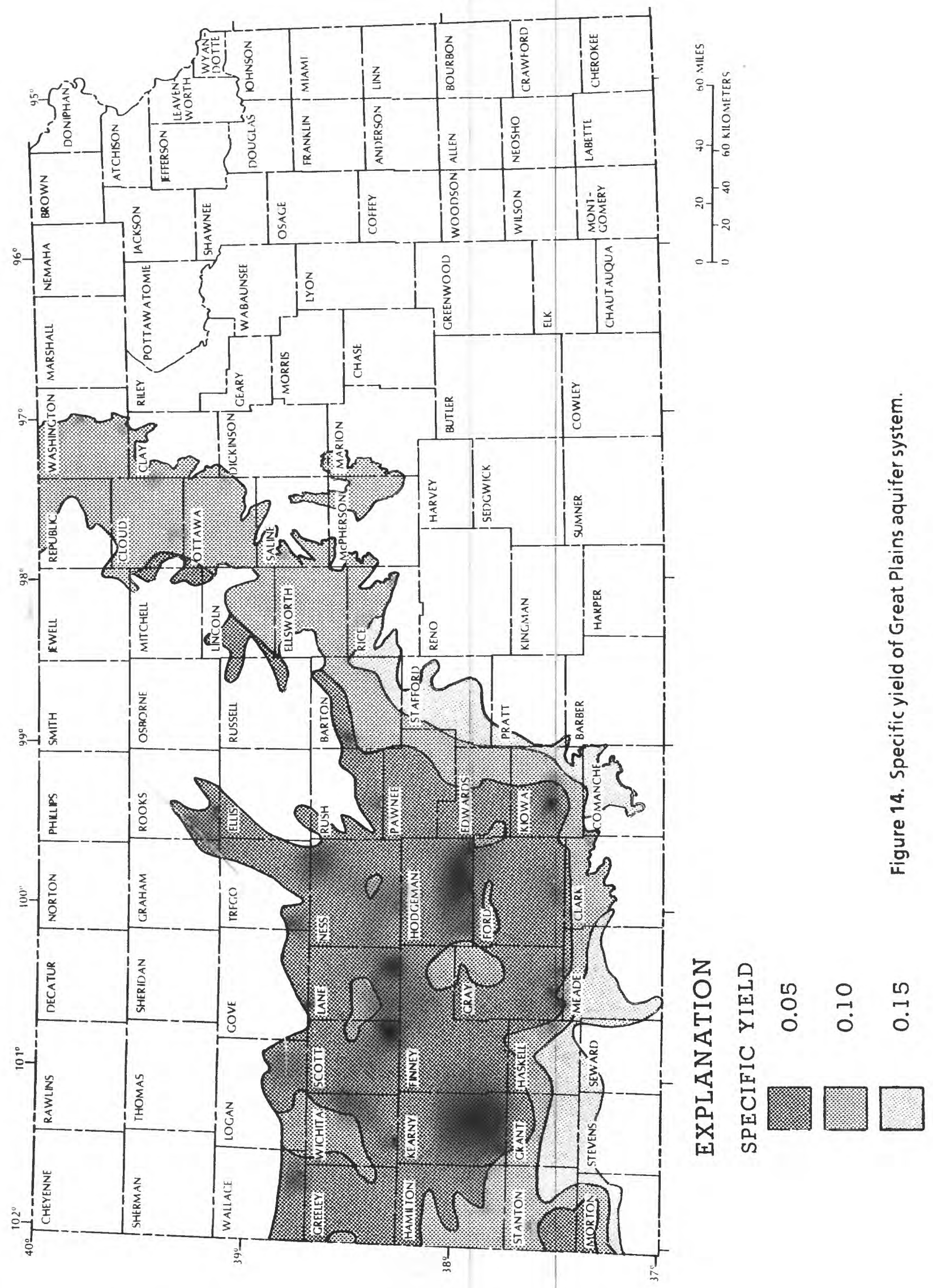




\section{Ozark Aquifer}

Freshwater in storage in the Ozark aquifer was estimated to be $26,100,000$ acre-feet (table 2). This is about four times larger than the $6,000,000$ acre-feet of potable water estimated by Hambleton (1984) to be in the Arbuckle Group. Freshwater storage in the Ozark aquifer increases to the south (fig. 8B) because the area underlain by the aquifer in each county also increases to the south (fig. 8A).

Saturated thickness of the Ozark aquifer ranges from less than 1,000 feet to more than 1,400 feet (plate 2). The same method used to estimate the saturated thickness of the Great Plains aquifer system was used to estimate the saturated thickness of the Ozark aquifer. The maps used to estimate the saturated thickness are also unpublished maps on file with the U.S. Geological Survey (Lawrence, Kansas). The area of the Ozark aquifer with dissolved-solids concentrations less than $1,000 \mathrm{mg} / \mathrm{L}$ was based on a report by Jorgensen and others (1986). In parts of the Ozark aquifer, the water quality. decreases with depth (Macfarlane and others, 1981). Not enough is known about the occurrence of this poorer quality water in the Ozark aquifer to exclude those parts of the aquifer that contain water with dissolved-solids concentrations greater than $1,000 \mathrm{mg} / \mathrm{L}$ at depth from the estimates of saturated thickness and freshwater storage made in this study.

For carbonate rocks, such as those that make up the Ozark aquifer, much of the porosity, and therefore, the specific yield, is dependent on unpredictable fractures and solution openings. In these instances, porosity is the best available approximation for specific yield. The average porosity of the rocks in the Ozark aquifer in southeastern Kansas was estimated to be 5 percent; therefore, a specific yield of 0.05 was chosen for the Ozark aquifer. No natural recharge to the Ozark aquifer was considered to be taking place in Kansas because the aquifer does not directly underlie the soil at land surface anywhere in the State.

\section{SUMMARY AND CONCLUSIONS}

The principal aquifers in Kansas are defined in this report as (1) alluvial aquifers, (2) glacial- drift aquifers, (3) the High Plains aquifer, (4) the Great Plains aquifer system, and (5) the Ozark aquifer. The aquifers in alluvial and glacialdrift deposits and the High Plains aquifer consist of unconsolidated, and usually unconfined, deposits of sand, gravel, silt, and clay. The Great Plains aquifer system and the Ozark aquifer are in consolidated rocks that usually occur in confined conditions.

Freshwater in storage that is available for use in each aquifer is defined as the volume of water with a dissolved-solids concentration less than $1,000 \mathrm{mg} / \mathrm{L}$. Freshwater in storage was estimated by multiplying the extent of the aquifer where it is saturated with freshwater by the aquifer's saturated thickness and then multiplying this by the specific yield.

Potential natural recharge is defined as the amount of water from precipitation that infiltrates across the water table to the saturated zone. Potential natural recharge was estimated by multiplying the area of the aquifer where it has some saturated thickness that directly underlies the soil at land surface by the rate of potential natural recharge. The rate of potential natural recharge was estimated by a computer model from land-use, soil, and climatic data.

Freshwater in storage in all the principal aquifers in Kansas is estimated by this study to be $590,000,000$ acre-feet. Freshwater in storage is estimated to be about $292,000,000$ acre-feet in the aquifers in unconsolidated deposits and about 297,000,000 acre-feet in the aquifers in consolidated rocks. Most of the freshwater in storage is in western Kansas, and much of that is in the High Plains aquifer and Great Plains aquifer system.

Potential natural recharge to the principal aquifers in Kansas is about $3,990,000$ acre-feet per year. Potential natural recharge is estimated to be $3,660,000$ acre-feet per year to the aquifers in unconsolidated deposits and about 323,000 acre-feet per year to the Great Plains aquifer system. Although the volume of recharge appears evenly distributed across the State, this is due to greater rates with small areas of recharge in eastern Kansas and lesser rates with large areas of recharge in western Kansas. 
Freshwater in storage in the alluvial aquifers is estimated to be $12,700,000$ acre-feet. Saturated thickness ranges from near zero to more than 120 feet. Specific yield ranges from 0.1 to 0.2 and averages 0.16 . Potential natural recharge to the alluvial aquifers is estimated to be $1,470,000$ acre-feet per year.

The glacial-drift aquifers are estimated to have 12,400,000 acre-feet of freshwater in storage. Saturated thickness of the aquifers in glacial deposits ranges from near zero to more than 320 feet. Specific yield of the glacial-drift aquifers is estimated to be 0.15 . Potential natural recharge to the aquifers in glacial-drift deposits is about 663,000 acre-feet.

About 267,000,000 acre-feet of freshwater are estimated to be in storage in the High Plains aquifer. The saturated thickness of this aquifer ranges from near zero to more than 560 feet. Specific yield ranges from 0.05 to 0.2 and averages 0.15. Potential natural recharge is estimated to be $1,530,000$ acre-feet per year to the High Plains aquifer.

Freshwater in storage in the Great Plains aquifer system is estimated to be $271,000,000$ acre-feet. Saturated thickness of the Great Plains aquifer system ranges from near zero to more than 800 feet. Specific yield ranges from 0.05 to 0.15 and averages 0.06 . About 323,000 acre-feet per year is the estimate of potential natural recharge to the Great Plains aquifer system.

There are about $26,100,000$ acre-feet of freshwater in storage in the Ozark aquifer. Saturated thickness of this aquifer ranges from less than 1,000 to more than 1,400 feet. Specific yield is estimated to be 0.05 for the Ozark aquifer. There is no natural recharge to the Ozark aquifer in Kansas because it does not directly underlie the soil at land surface anywhere in the State.

The estimate made by this study of freshwater in storage in all the principal aquifers in Kansas is more than one-third larger than estimates made by previous investigators. Estimates for the aquifers in unconsolidated deposits are about the same, but estimates for the aquifers in consolidated rocks were several times larger. Most of the increased estimates for both unconsolidated and consolidated aquifers probably are due to differences in methods of estimating saturated thickness; other investigators may have tried to estimate effective thickness or may have excluded the deeper parts of the aquifers that may contain poorer quality water. Also, the extent of Great Plains aquifer system used in this study may be larger than the extent considered in previous investigations.

Estimates of potential natural recharge made by this study tend to be somewhat larger than those made by previous studies, especially for western Kansas. The actual rate of natural recharge may be somewhere between previous estimates and the ones made by this study.

\section{SELECTED REFERENCES}

Barker, R.A., Dunlap, L.E., and Sauer, C.G., 1983, Analysis and computer simulation of stream-aquifer hydrology, Arkansas River valley, southwestern Kansas: U.S. Geological Survey Water-Supply Paper 2200, $59 \mathrm{p}$.

Bayne, C.K., 1975, Map showing bedrock surface: Lawrence, unpublished map of the Kansas Geological Survey, scale 1:1,000,000, 1 sheet.

Bayne, C.K., and Ward, J.R., 1969, Saturated thickness and specific yield of Cenozoic deposits in Kansas: Kansas Geological Survey Map M-5, scale 1:500,000, 1 sheet.

Bevans, H.E., Spruill, T.B., and Kenny, J.F., 1985, Kansas, in National Water Summary 1984-Hydrologic events, selected waterquality trends, and ground-water resources: U.S. Geological Survey Water-Supply Paper 2275, p. 217-222.

Cady, R.E., and Peckenpaugh, J.M., 1985, Documentation of RAQSIM-A regional aquifer simulation model and its use in the Twin Platte-Middle Republican study area, Nebraska: U.S. Geological Survey WaterResources Investigations Report 85-4168, $239 \mathrm{p}$. 
Denne, J.E., Steeples, D.W., Sophocleous, M.A., Severini, A.F., and Lucas, J.R., 1982, An integrated approach for locating glacial buried valleys: Kansas Geological Survey Ground-Water Series 5, 22 p.

Dugan, J.T., and Peckenpaugh, J.M., 1985, Effects of climate, vegetation, and soils on consumptive water use and ground-water recharge to the Central Midwest regional aquifer system, mid-continent United States: U.S. Geological Survey Water-Resources Investigations Report 85-4236, 78 p.

Fader, S.W., 1968, Ground water in the Republican River area, Cloud, Jewell, and Republican Counties, Kansas: Kansas Geological Survey Bulletin 188, 27 p.

1974, Ground water in the Kansas River valley, Junction City to Kansas City, Kansas: Kansas Geological Survey Bulletin 206, part 2, 12 p.

Fader, S.W., and Morton, R.B., 1975a, Ground water in the Middle Arkansas River basin, Kansas and Oklahoma: U.S. Geological Survey Open-File Report 75-367, 44 p.

$1975 \mathrm{~b}$, Ground water in the Verdigris River basin, Kansas and Oklahoma: U.S. Geological Survey Open-File Report 73-365, $26 \mathrm{p}$.

Fader, S.W., and Stullken, L.E., 1978, Geohydrology of the Great Bend Prairie, south-central Kansas: Kansas Geological Survey Irrigation Series 4, $19 \mathrm{p}$.

Fishel, V.C., 1952, Ground-water resources of Pawnee Valley, Kansas: Kansas Geological Survey Bulletin 94, 144 p.

Freeze, R.A., and Cherry, J.A., 1979, Groundwater: Englewood, New Jersey, Prentice-Hall, 604 p.

Frye, J.C., 1952, Pleistocene geology of Kansas: Kansas Geological Survey Bulletin 99, 230 p.

Gogel, Tony, 1981, Discharge of saltwater from
Permian rocks to major stream-aquifer systems in central Kansas: Kansas Geological Survey Chemical Quality Series $9,60 \mathrm{p}$.

Gutentag, E.D., Lobmeyer, D.H., and McGovern, H.E., 1972, Ground water in Kearny County, southwestern Kansas: U.S. Geological Survey Hydrologic Investigations Atlas HA416, scale 1:250,000, 2 sheets.

Gutentag, E.D., Lobmeyer, D.H., McGovern, H.E., and Long, W.A., 1972, Ground water in Finney County, southwestern Kansas: U.S. Geological Survey Hydrologic Investigations Atlas HA-442, scale 1:250,000, 3 sheets.

Gutentag, E.D., Lobmeyer, D.H., and Slagle, S.E., 1981, Geohydrology of southwestern Kansas: Kansas Geological Survey Irrigation Series 7, 73 p.

Gutentag, E.D., and Stullken, L.E., 1974, Ground water in Haskell County, southwestern Kansas: U.S. Geological Survey Hydrologic Investigations Atlas HA515 , scale $1: 250,000,2$ sheets.

Hambleton, W.W., 1984, Ground water (or well, what is the song, then?): Kansas Geological Survey, The Journal, v. 6, no. 2, p. 21-26.

Hathaway, L.R., Carr, B.L., Flanagan, M.A., Galle; O.K., Waugh, T.C., Dickey, H.P., and Magnuson, L.M., 1978, Chemical quality of irrigation waters in southwestern Kansas: Kansas Geological Survey Chemical Quality Series 6, $35 \mathrm{p}$.

Hathaway, L.R., Carr, B.L., Galle, O.K., Magnuson, L.M., Waugh, T.C., and Dickey, H.P., 1977, Chemical quality of irrigation waters in Hamilton, Kearny, Finney, and northern Gray Counties: Kansas Geological Survey Chemical Quality Series 4, 33 p.

Hathaway, L.R., Galle, O.K., Waugh, T.C., and Dickey, H.P., 1978, Chemical quality of irrigation waters in Ford County and the Great Bend Prairie of Kansas: Kansas Geological Survey Chemical Quality Series 7, $41 \mathrm{p}$. 
Hathaway, L.R., Magnuson, L.M., Carr, B.L., Galle, O.K., and Waugh, T.C., 1975, Chemical quality of irrigation waters in west-central Kansas: Kansas Geological Survey Chemical Quality Series 2, 46 p.

Hathaway, L.R., Waugh, T.C., Galle, O.K., and Dickey, H.P., 1979, Chemical quality of irrigation waters in northwestern Kansas: Kansas Geological Survey Chemical Quality Series 8, $45 \mathrm{p}$.

Hathaway, L.R., Waugh, T.C., Galle, O.K., and Dickey, H.P., 1981, Chemical quality of irrigation waters in the Equus beds area, south-central Kansas: Kansas Geological Survey Chemical Quality Series 10,45 p.

Heath, R.C., 1983, Basic ground-water hydrology: U.S. Geological SurveyWaterSupply Paper 2220, 84 p.

Hem, J.D., 1985, Study and interpretation of the chemical characteristics of natural water (3rd ed.): U.S. Geological Survey WaterSupply Paper 2254, 263 p.

Jensen, M.E., and Haise, H.R., 1963, Estimating evapotranspiration from solar radiation: Journal of the Irrigation and Drainage Division, Proceedings of the American Society of Civil Engineers, v. 89, no. IR4, p. 15-41.

Jensen, M.E., Robb, D.C.N., and Franzoy, C.E., 1970 , Scheduling irrigations using climatecrop-soil data: Journal of the Irrigation Division, Proceedings of the American Society of Civil Engineers, v. 96, no. IR1, p. 25-38.

Jorgensen, D.G., Helgesen, J.O., and Imes, J.L., (in press), Regional aquifers in Kansas, Nebraska, and parts of Arkansas, Colorado, Missouri, New Mexico, Oklahoma, South Dakota, Texas, and Wyoming-Geohydrologic framework: U.S. Geological Survey Professional Paper 1414B.

Jorgensen, D.G., Helgesen, J.O., Leonard, R.B., and Signor, D.C., 1986, Equivalent freshwater head and dissolved-solids concentration of water in rocks of Cambrian, Ordovician, and Mississippian age in the northern Midcontinent, U.S.A.: U.S. Geological Survey Miscellaneous Field Studies Map MF-1835-B, scale 1:1,000,000, 2 sheets.

Kansas Department of Health and

Environment,1984, Summary of available water quality criteria and standards: Topeka, Kansas Department of Health and Environment, Quality Assessment Section, 6 p.

1985, Ceneral rules and regulations for the conservation of crude oil and natural gas, definitions and rules: Topeka, Kansas Department of Health and Environment, Oil and Gas Section, 82-3-101-(28).

Kansas Geological Survey, 1964, Geologic map of Kansas: Kansas Geological Survey Map Series M-1, scale 1:500,000, 1 sheet.

Kansas Water Office, 1984, Kansas water supply and demand estimates: State Water Plan Background Paper 15, $119 \mathrm{p}$.

Kansas Water Resources Board, 1967, Irrigation in Kansas: State of Kansas, Planning for Development Report No. 16(e), 23 p. (numerous unnumbered plates).

Keene, K.M., and Bayne, C.K., 1977, Ground water from Lower Cretaceous rocks in Kansas: Kansas Geological Survey Chemical Quality Series 5, 18 p.

Krothe, N.C., Oliver, J.W., and Weeks, J.B., 1982, Dissolved solids and sodium in water from the High Plains aquifer in parts of Colorado, Kansas, Nebraska, New Mexico, Oklahoma, South Dakota, Texas, and Wyoming: U.S. Geological Survey Hydrologic Investigations Atlas HA-658, scale $1: 2,500,000,2$ sheets.

Lappala, E.G. 1978, Quantitative hydrogeology of the Upper Republican Natural Resources District, southwest Nebraska: U.S. Geological Survey Water-Resources Investigations 73-38, $200 \mathrm{p}$. 
Latta, B.F., 1949, Ground-water conditions in the Smoky Hill valley in Saline, Dickinson, and Geary Counties, Kansas: Kansas Geological Survey Bulletin 84, 152 p.

Leonard, A.R., and Berry, D.W., 1961, Geology and ground-water resources of southern Ellis County and parts of Trego and Rush Counties, Kansas: Kansas Geological Survey Bulletin 149, 156 p.

Leonard, R.B., and Kleinschmidt, M.K., 1976, Saline water in the Little Arkansas River basin area, south-central Kansas: Kansas Geological Survey Chemical Quality Series 3, $24 \mathrm{p}$.

Lobmeyer, D.H., and Sauer, C.G., 1974, Water resources of Hamilton County, southwestern Kansas: U.S. Geological Survey Hydrologic Investigations Atlas HA-516, scale 1:250,000 and 1:500,000, 2 sheets.

Lohman, S.W., 1979, Ground-water hydraulics: U.S. Geological Survey Professional Paper $708,70 \mathrm{p}$.

Lohman, S.W., and others, 1972, Definitions of selected ground-water terms--Revisions and conceptual refinements: U.S. Geological Survey Water-Supply Paper 1988, 21 p.

Macfarlane, P.A., Whittemore, Don, and Hathaway, L.R., 1981, The hydrogeology and chemical quality in the lower Paleozoic aquifers in southeast Kansas and adjoining areas of Missouri and Oklahoma: Kansas Geological Survey Open-File Report 81-16, $48 \mathrm{p}$.

McClain, T.J., Jenkins, E.D., Keene, K.M., and Pabst, M.E., 1975, Water resources of Gove, Logan, and Wallace Counties, west-central Kansas: U.S. Geological Survey Hydrologic Investigations Atlas HA-521, scale 1:250,000 and 1:500,000, 2 sheets.

McNellis, J.M., 1973, Geology and ground-water resources of Rush County, central Kansas: Kansas Geological Survey Bulletin 207, 45 p.
Morton, R.B., and Fader, S.W., 1975, Ground water in the Grand (Neosho) River basin, Kansas and Oklahoma: U.S. Geological Survey Open-File Report 75-366, 35 p.

Pabst, M.E., and Dague, B.J., 1984, January 1984 water levels, and data related to waterlevel changes, western and south-central Kansas: U.S. Geological Survey Open-File Report 84-613, 162 p.

Pabst, M.E., and Stullken, L.E., 1984, Altitude and configuration of the water table in the High Plains aquifer in Kansas, 1980: U.S. Geological Survey Open-File Report 81-1004, scale 1:500,000, 1 sheet.

Peckenpaugh, J.M., and Dugan J.T., 1983, Hydrogeology of parts of the Central Platte and Lower Loup Natural Resources Districts, Nebraska: U.S. Geological Survey WaterResources Investigations Report 83-4219, $125 \mathrm{p}$.

Reed, T.B., and Burnett, R.D., 1985, Compilation and analyses of aquifer performance tests in eastern Kansas: U.S. Geological Survey Open-File Report 85-200, $125 \mathrm{p}$.

Sophocleous, Marios, 1980, Hydrogeologic investigation in the Pawnee valley, Kansas: Kansas Geological Survey Open-File Report 80-6, 210 p.

Steeples, D.W., and Buchanan, Rex, 1983, Kansas geomaps: Kansas Geological Survey Educational Series 4, 30 p.

Stullken, L.E., Watts, K.R., and Lindgren, R.J., 1985, Geohydrology of the High Plains aquifer, western Kansas: U.S. Geological Survey Water-Resources Investigations Report 85-4198, 86 p.

U.S. Environmental Protection Agency, 1986a, Maximum contaminant levels (subpart B of part 141, National interim primary drinking-water regulations): U.S. Code of Federal Regulations, Title 40, Parts 100 to 149 , revised as of July 1, 1986, p. 524-528. 
1986b, Secondary maximum contaminant levels (section 143.3 of part 143, National secondary drinking-water regulations): U.S. Code of Federal Regulations, Title 40, Parts 100 to 149 , revised as of July 1,1986, p. 587 590.

U.S. Geological Survey, 1966, Ground water in the Cimarron River basin, New Mexico, Colorado, Kansas, and Oklahoma: U.S. Geological Survey Open-File Report, 51 p.

1976, Hydrologic unit map--1974, State of Kansas: U.S. Geological Survey, scale 1:500,000, 1 sheet.

Ward, J.R., 1973, Geohydrology of Atchison
County, northeastern Kansas: U.S. Geological Survey Hydrologic Investigations Atlas HA-467, scale 1:62,500, 2 sheets.

1974, Geohydrology of Nemaha County, northeastern Kansas: Kansas Geological Survey Ground-Water Series 2, 19 p.

Watts, K.R., and Stullken, L.E., 1981, Generalized configuration of the base of the High Plains aquifer in Kansas: U.S. Geological Survey Open-File Report 81-344, scale 1:500,000, 1 sheet.

Williams, C.C., and Lohman, S.W., 1949, Geology and ground-water resources of a part of south-central Kansas: Kansas Geological Survey Bulletin 79, 455 p. 


\section{SUPPLEMENTAL INFORMATION}

The tables presented in this section were compiled as a part of this study for the Kansas Water Office. The State of Kansas was divided into 12 major river basins (fig. 15) by the Kansas Water Office. The boundaries of the river basins were chosen to coincide in most places with boundaries shown on the hydrologic unit map of
Kansas (U.S. Geological Survey, 1976). The 12 river basins were separated into those areas that belong to each of the 105 counties in the State. In each of these smaller areas, freshwater storage and potential natural recharge were estimated for each of the five principal aquifers. Aggregate totals of freshwater storage and potential natural recharge for each river basin, county, and aquifer also were estimated. 


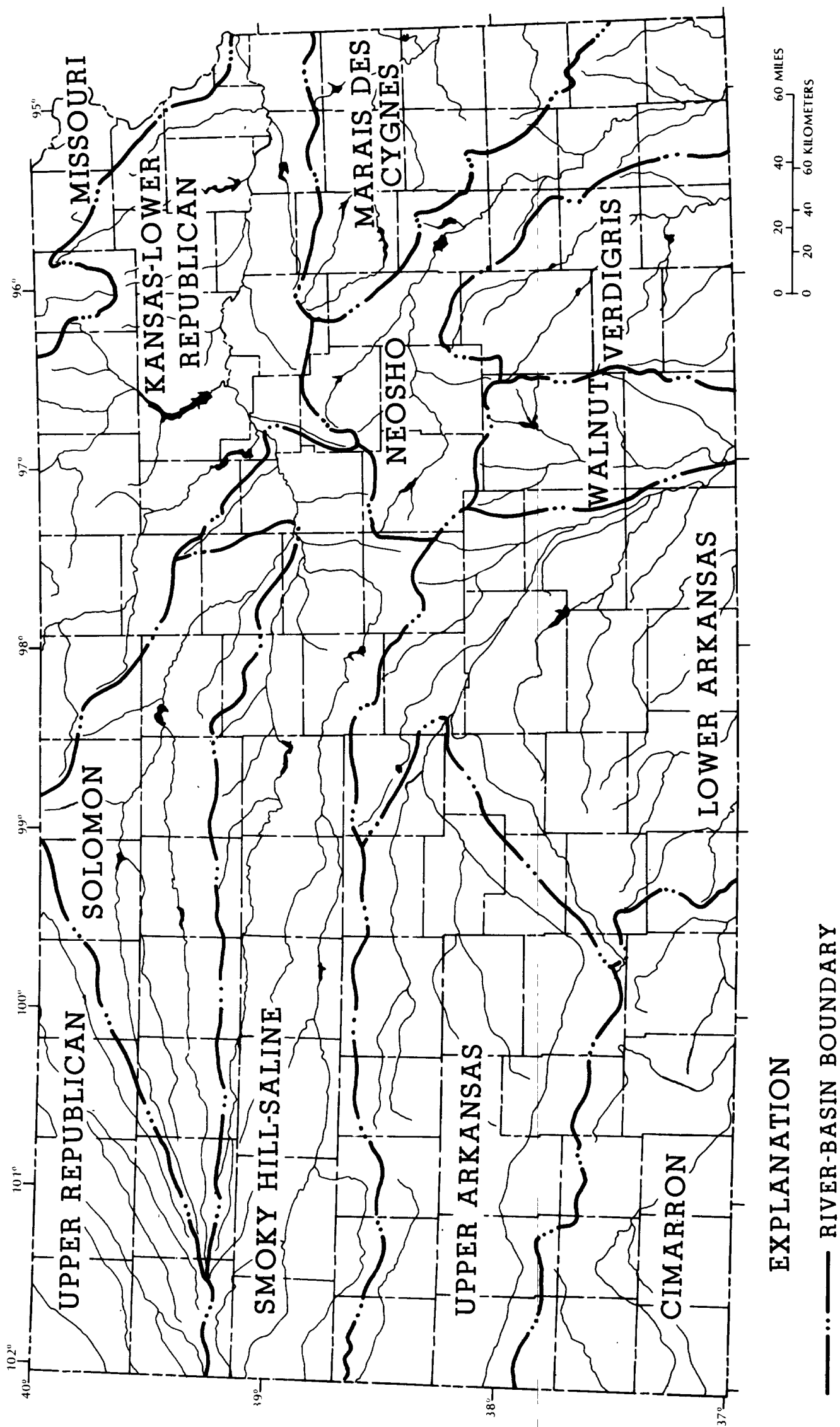

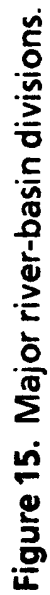




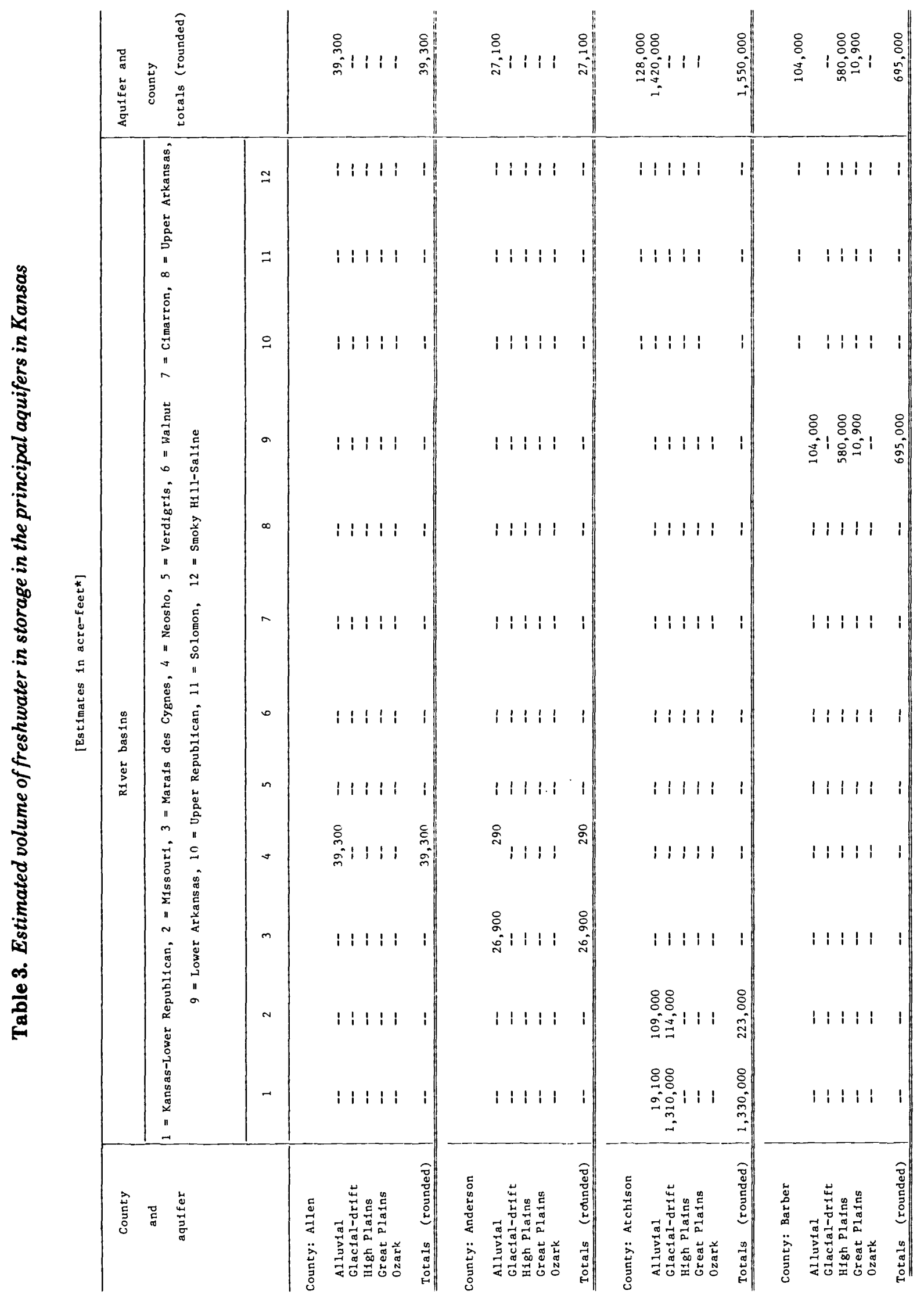




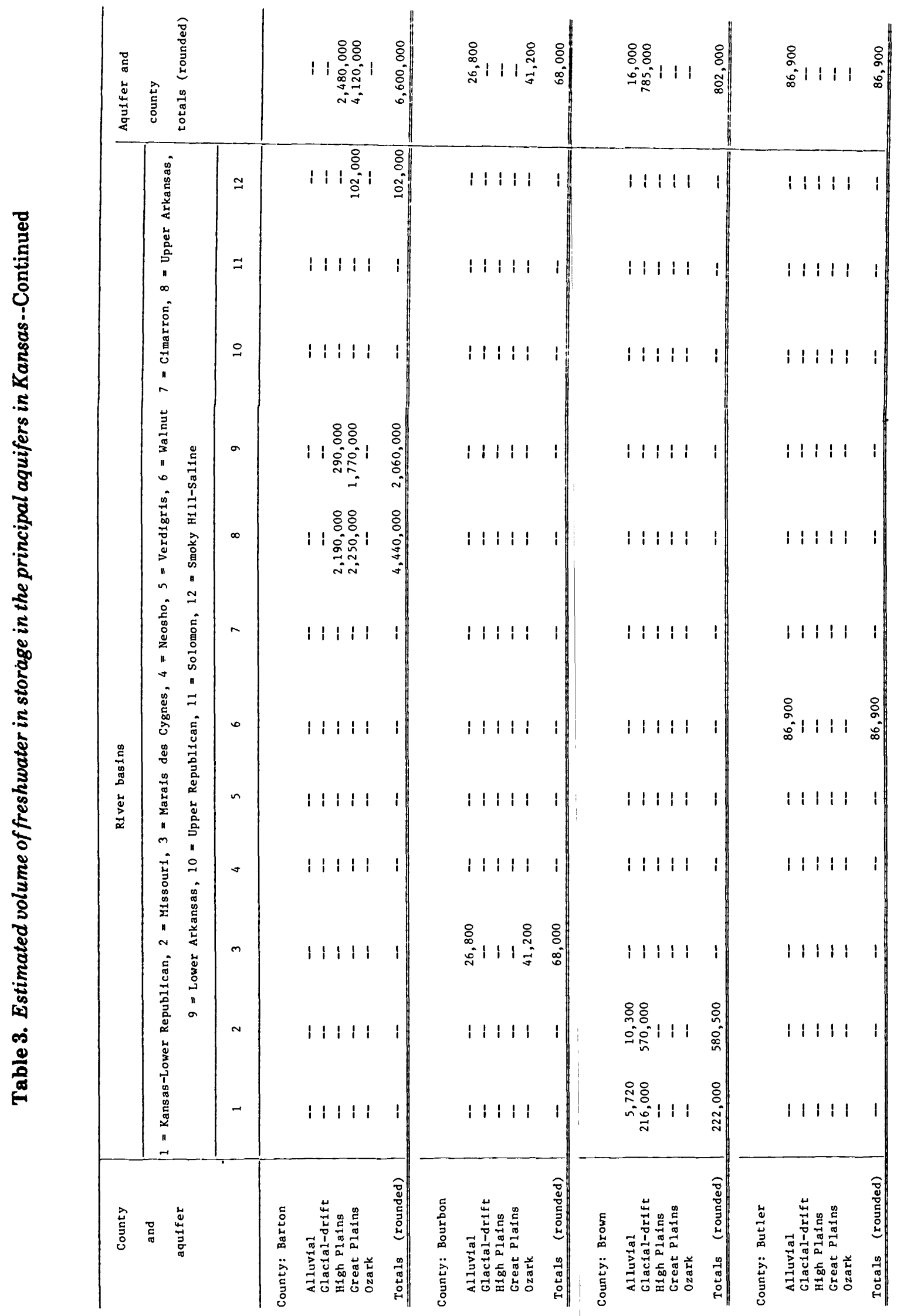




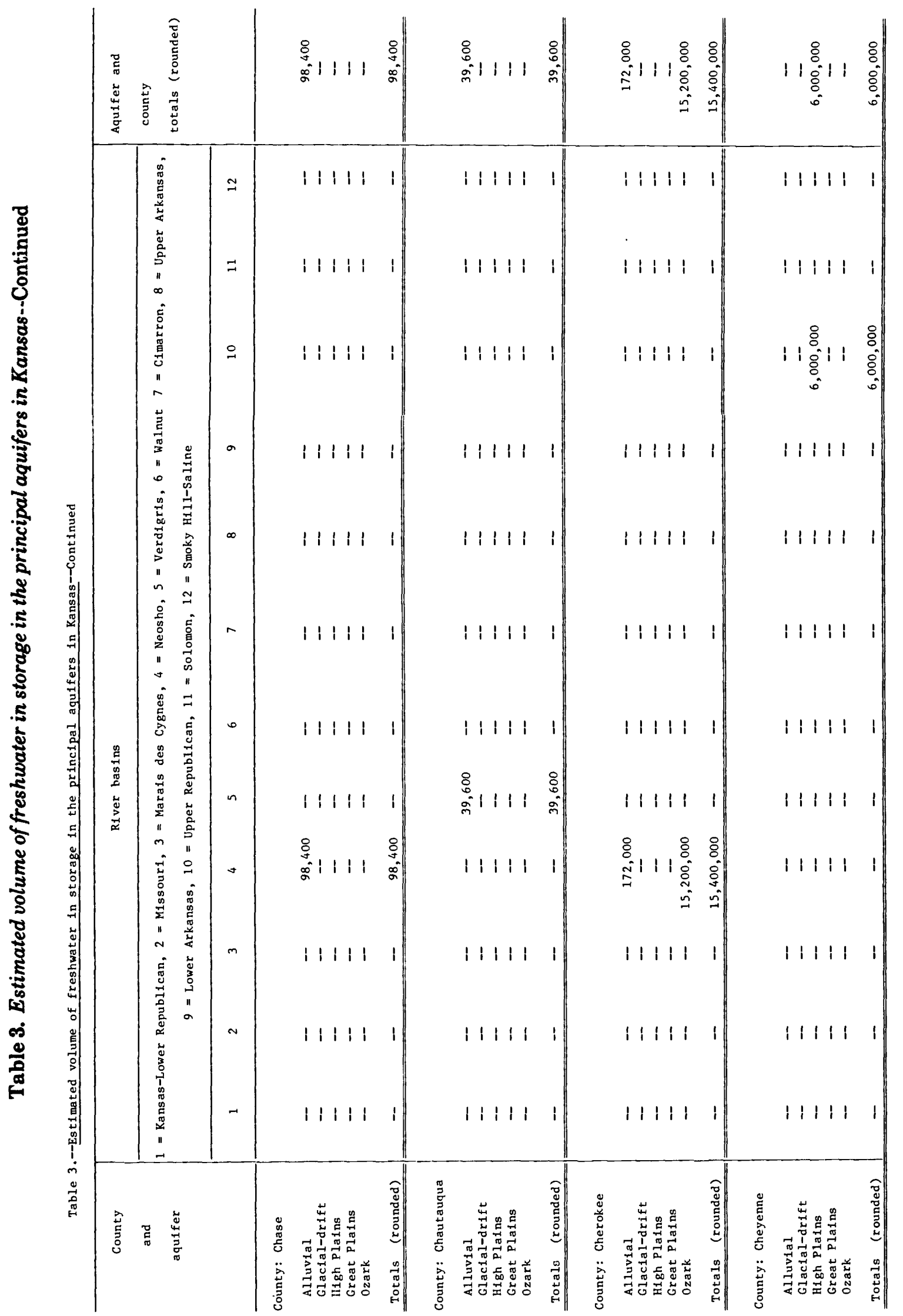




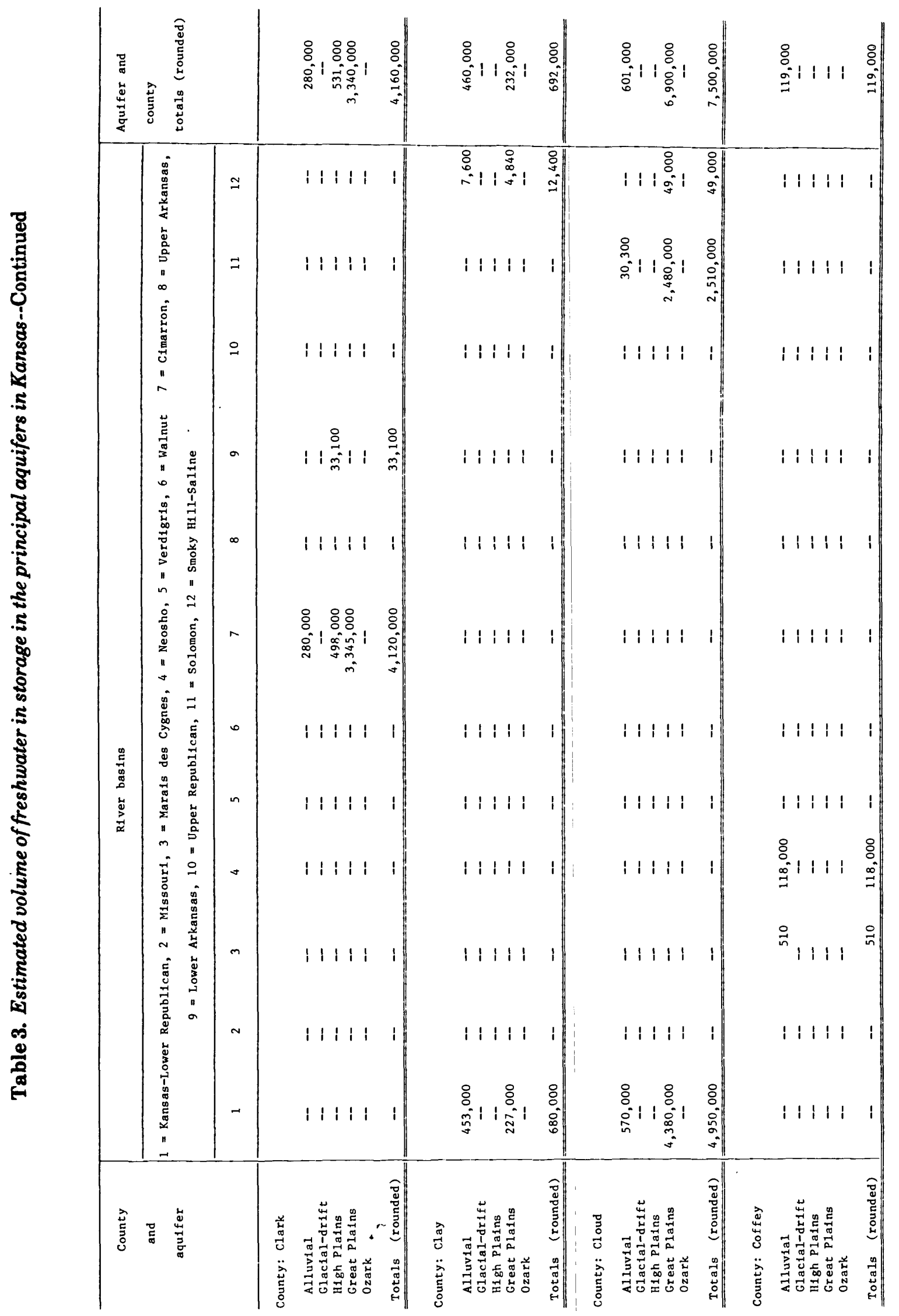




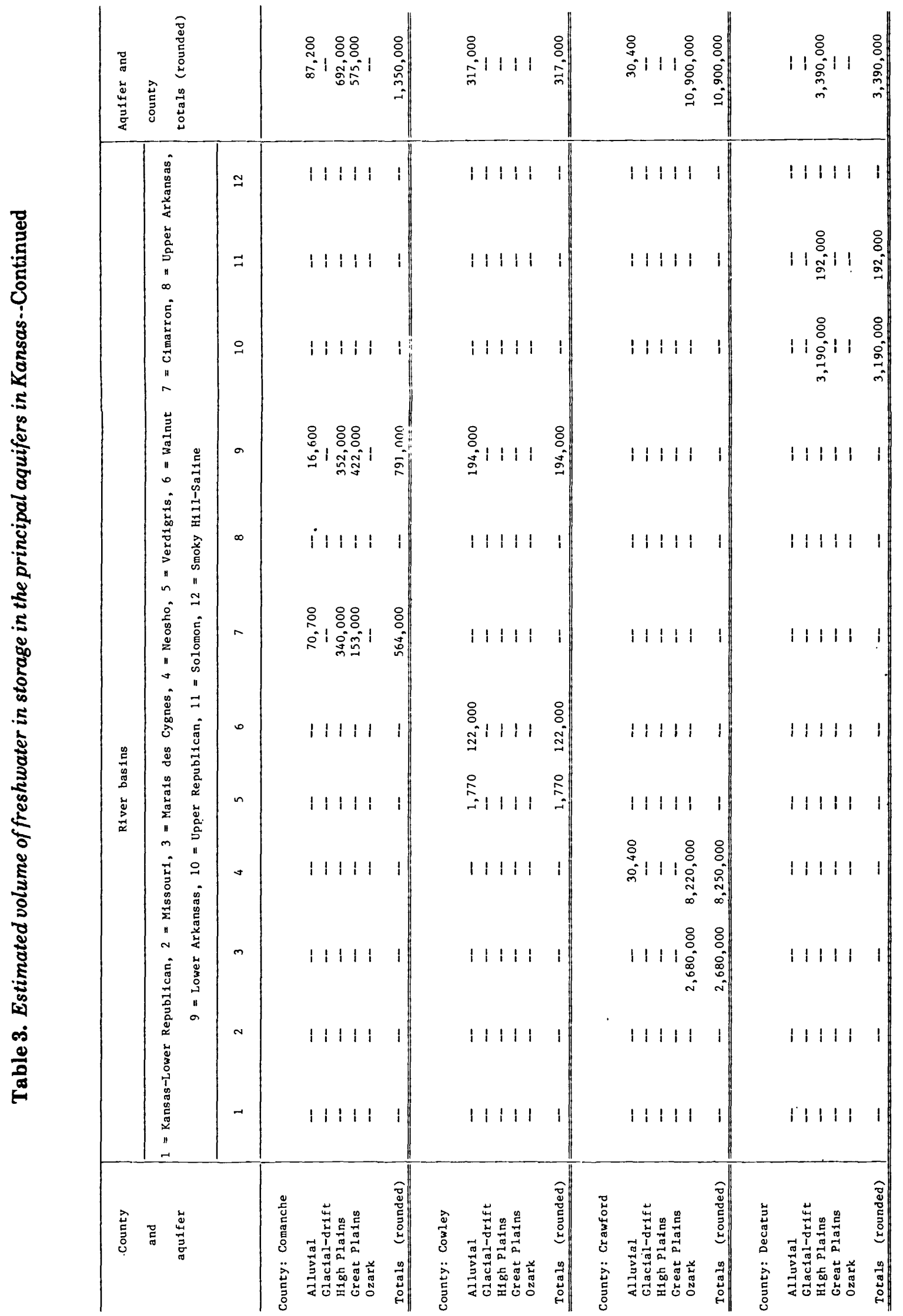




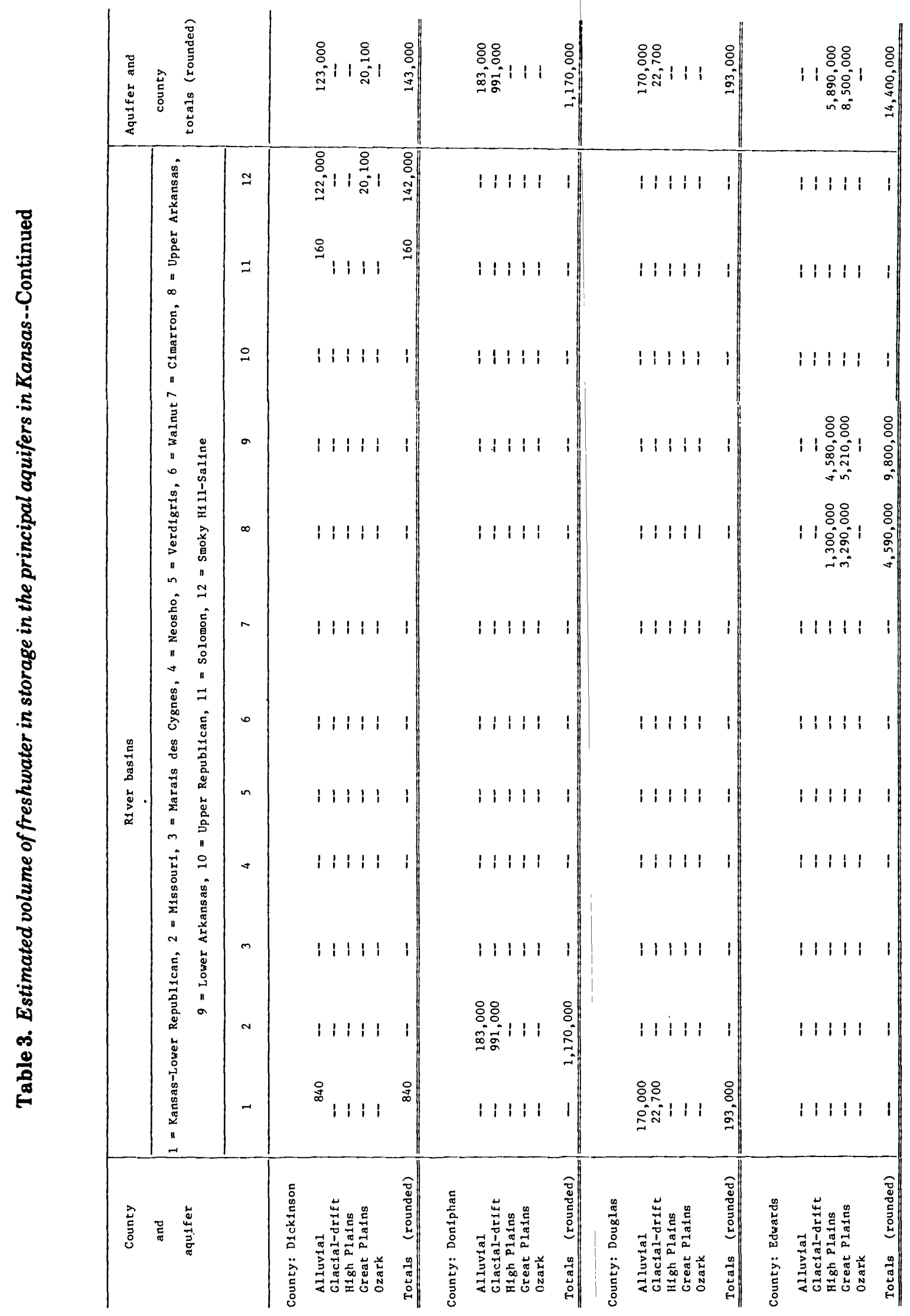




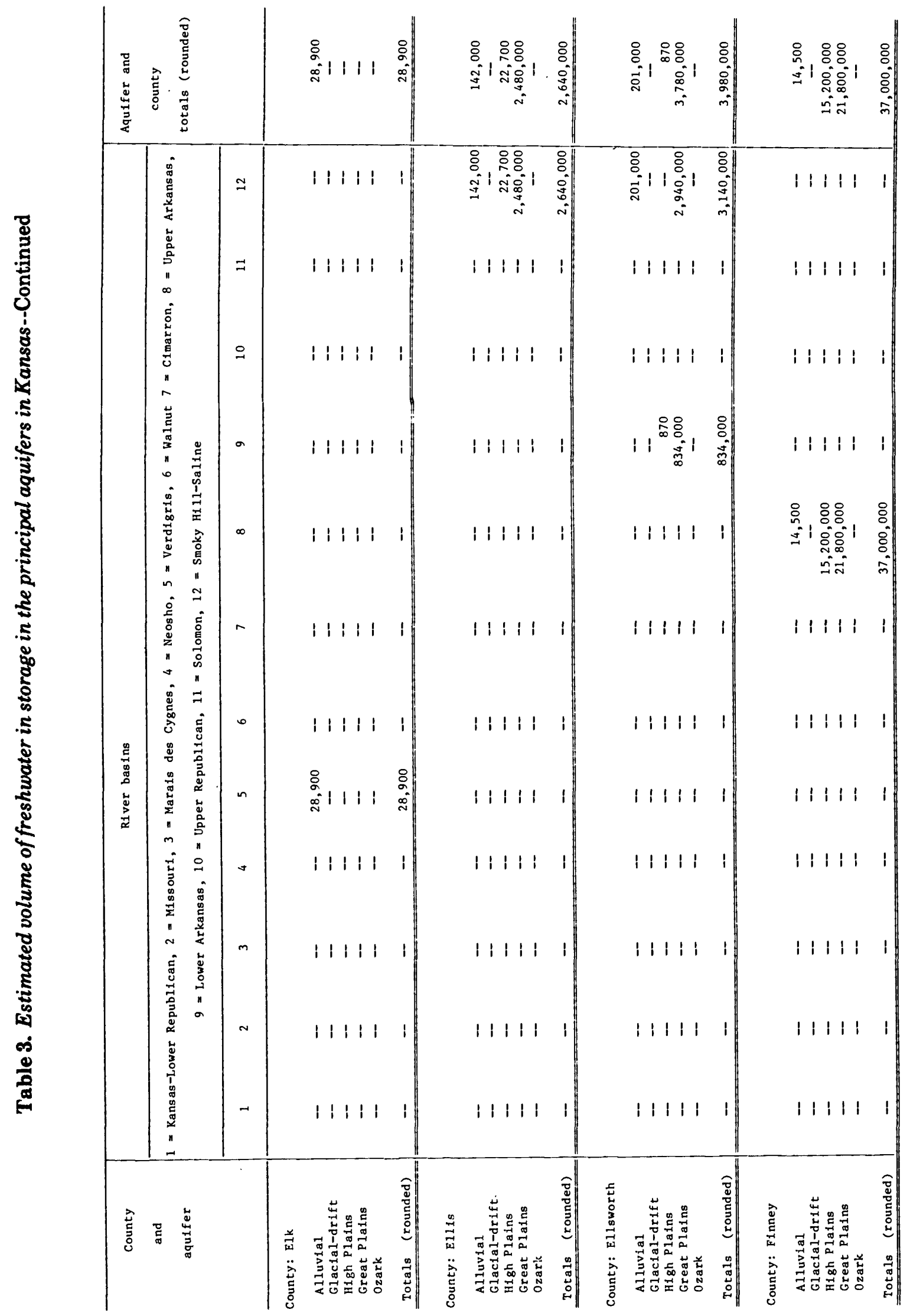




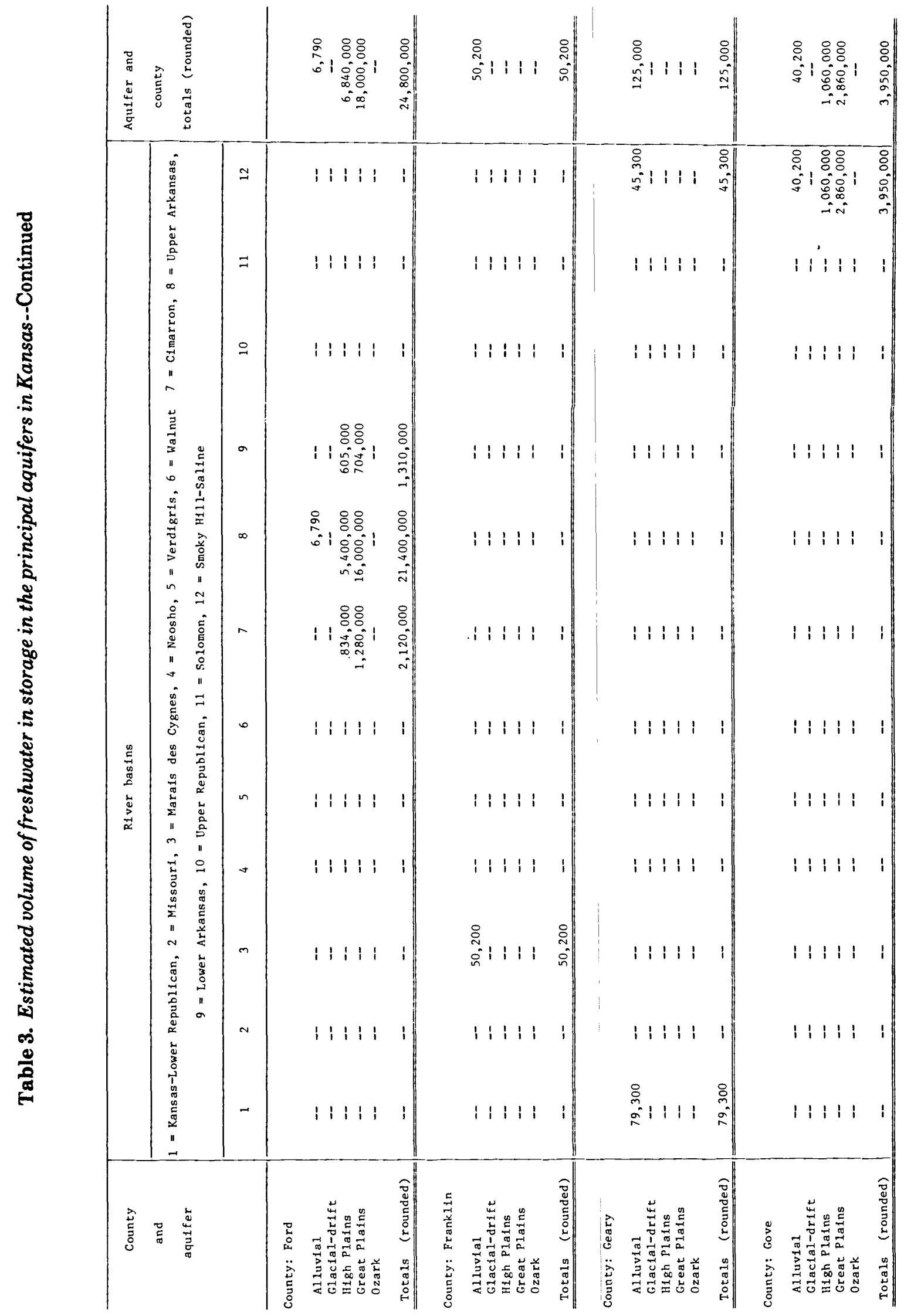




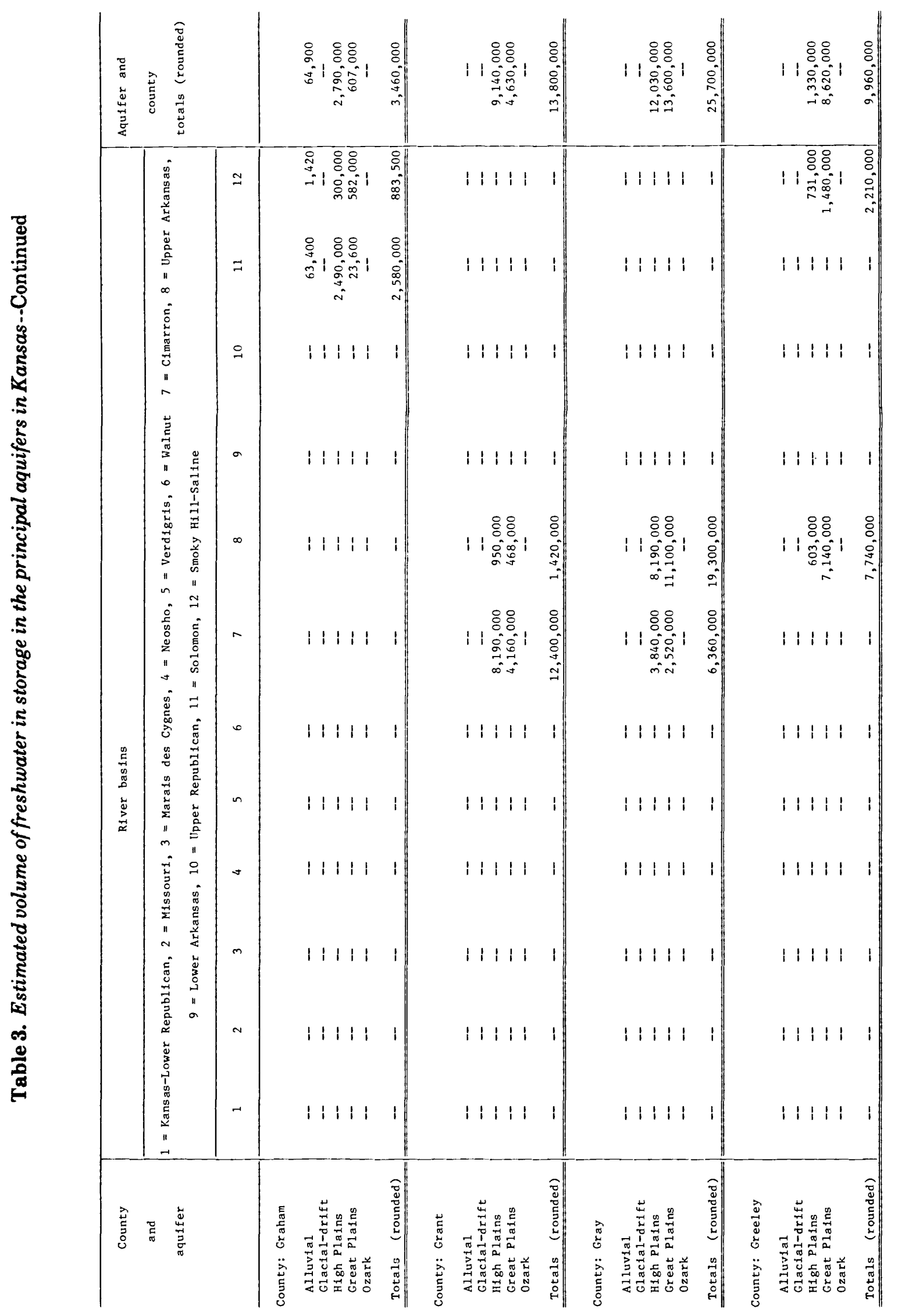




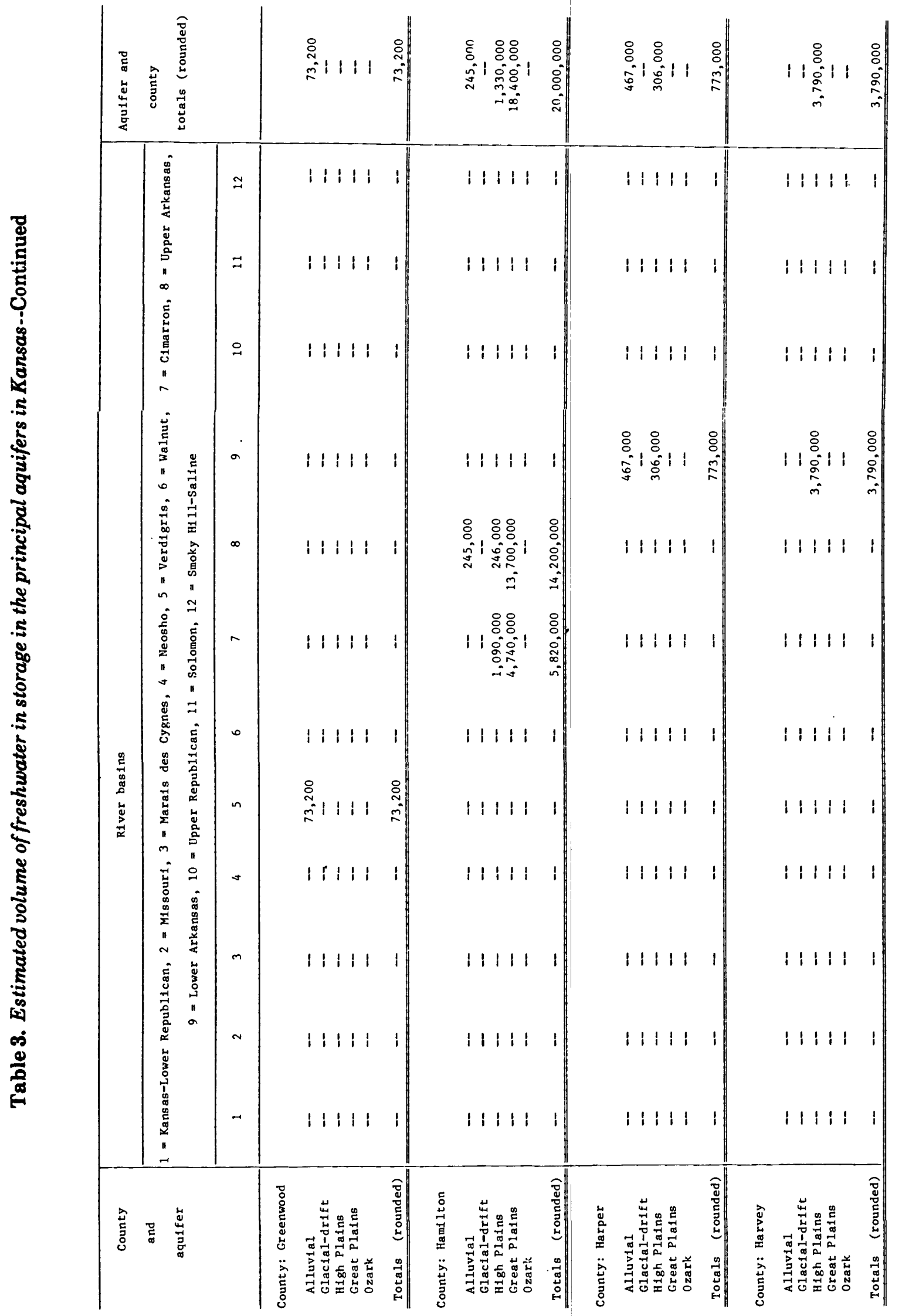




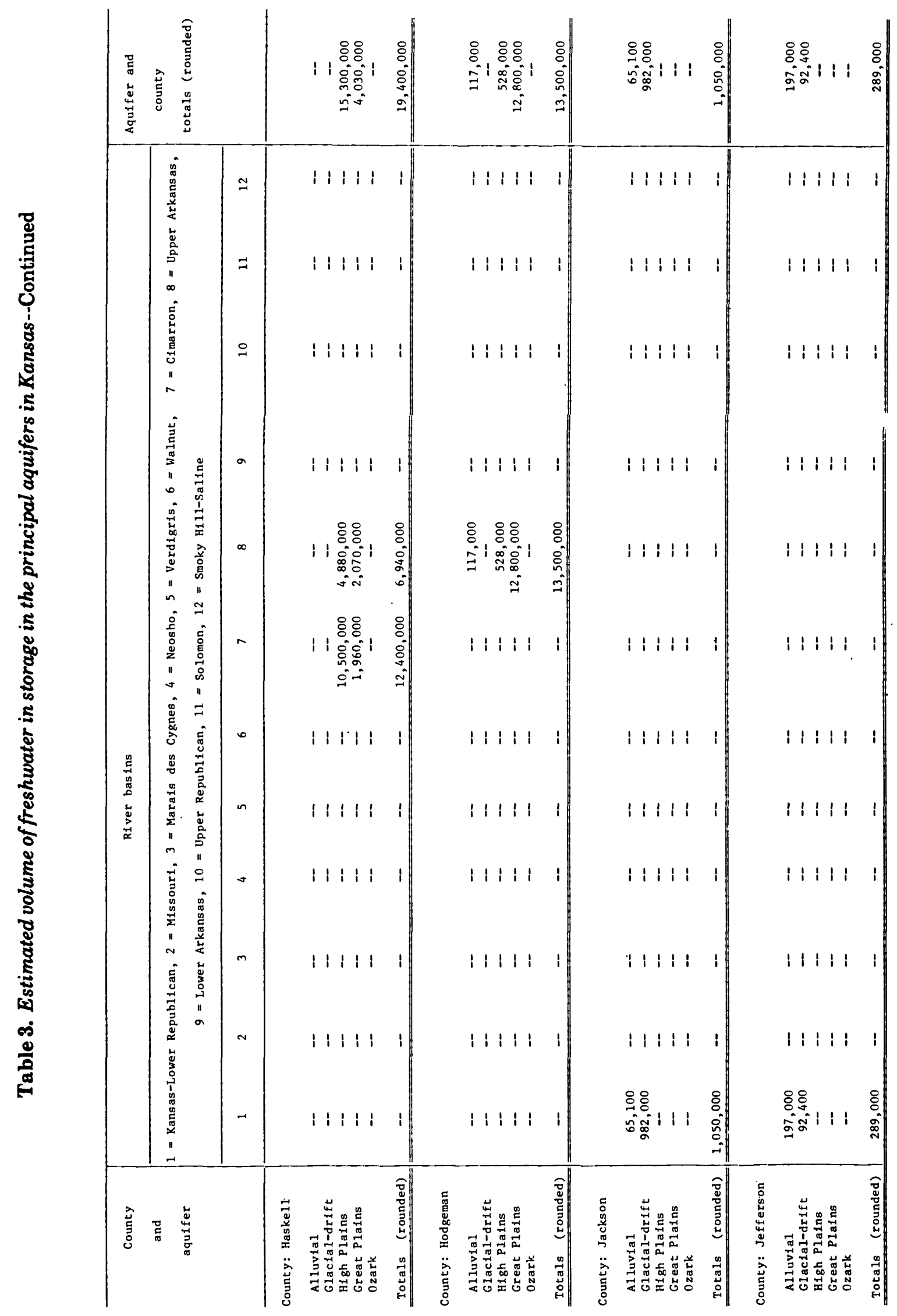




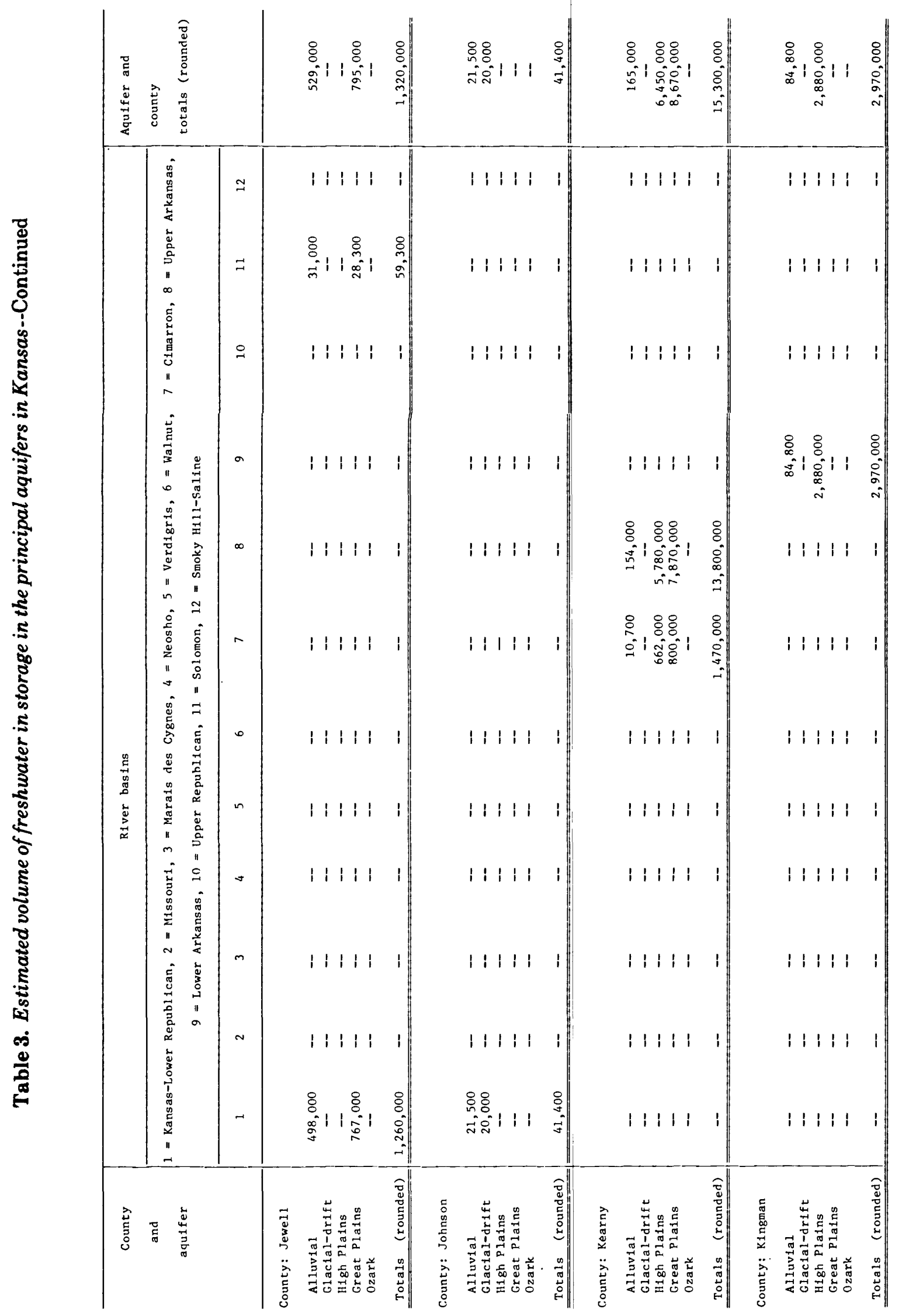




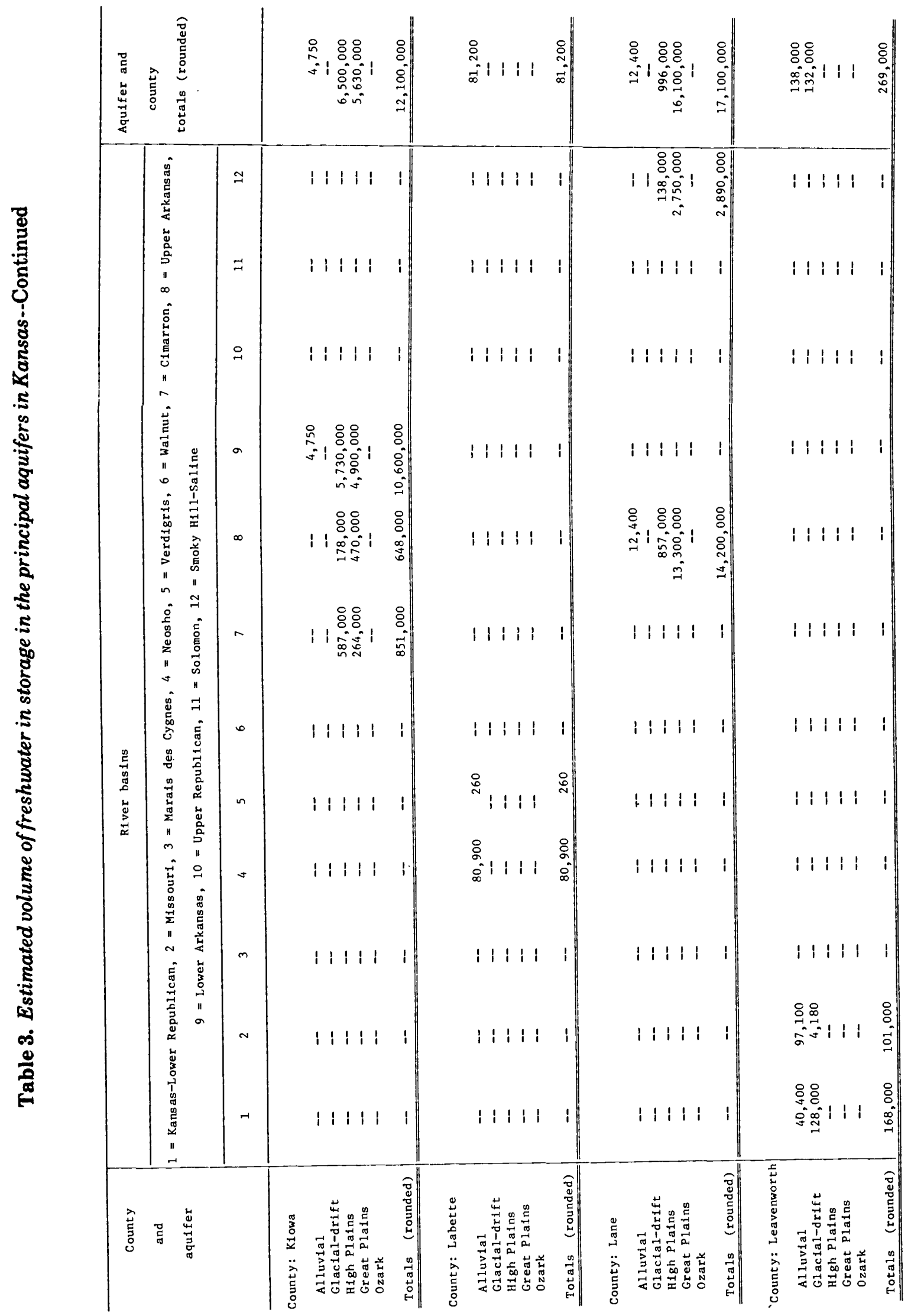




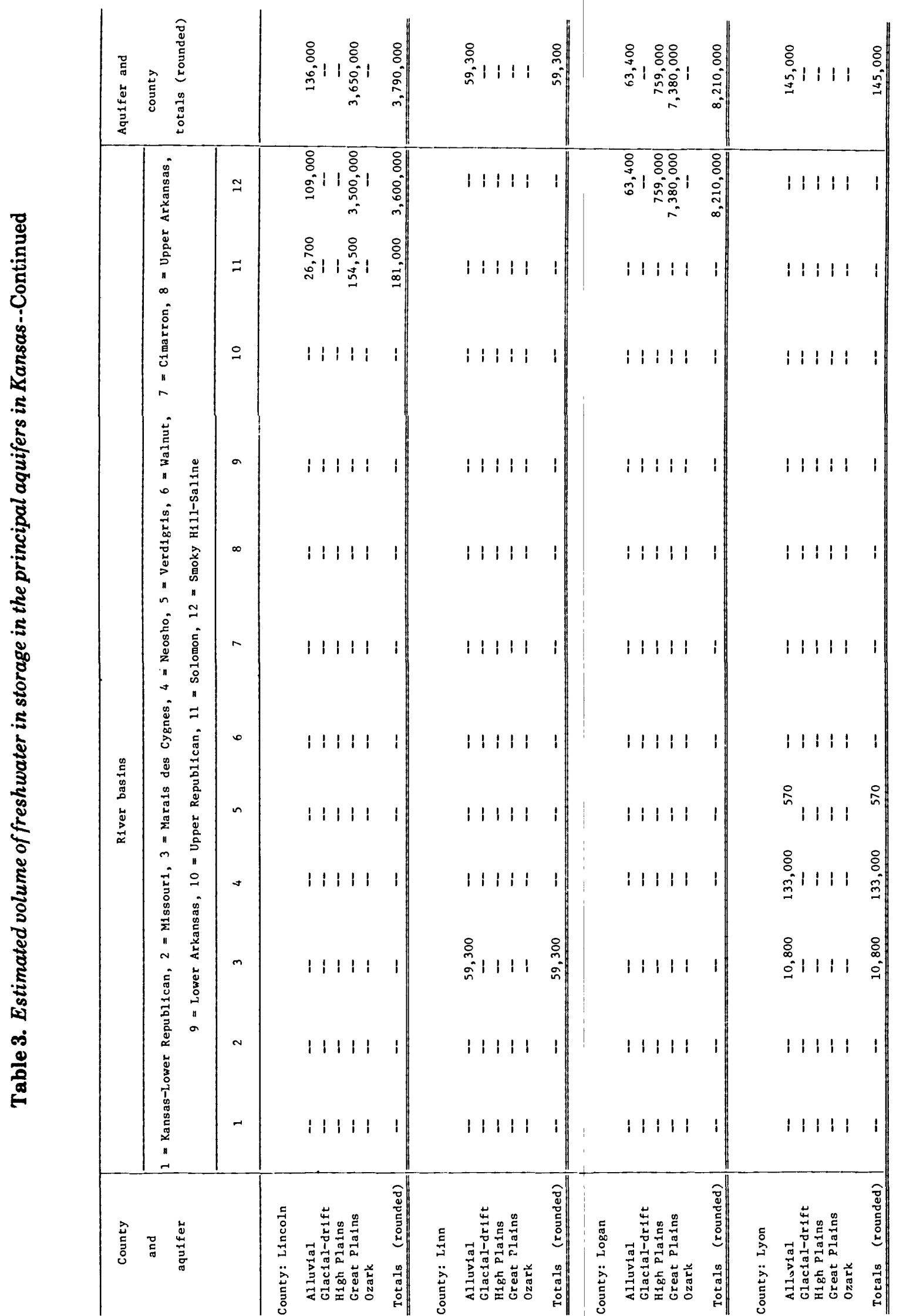




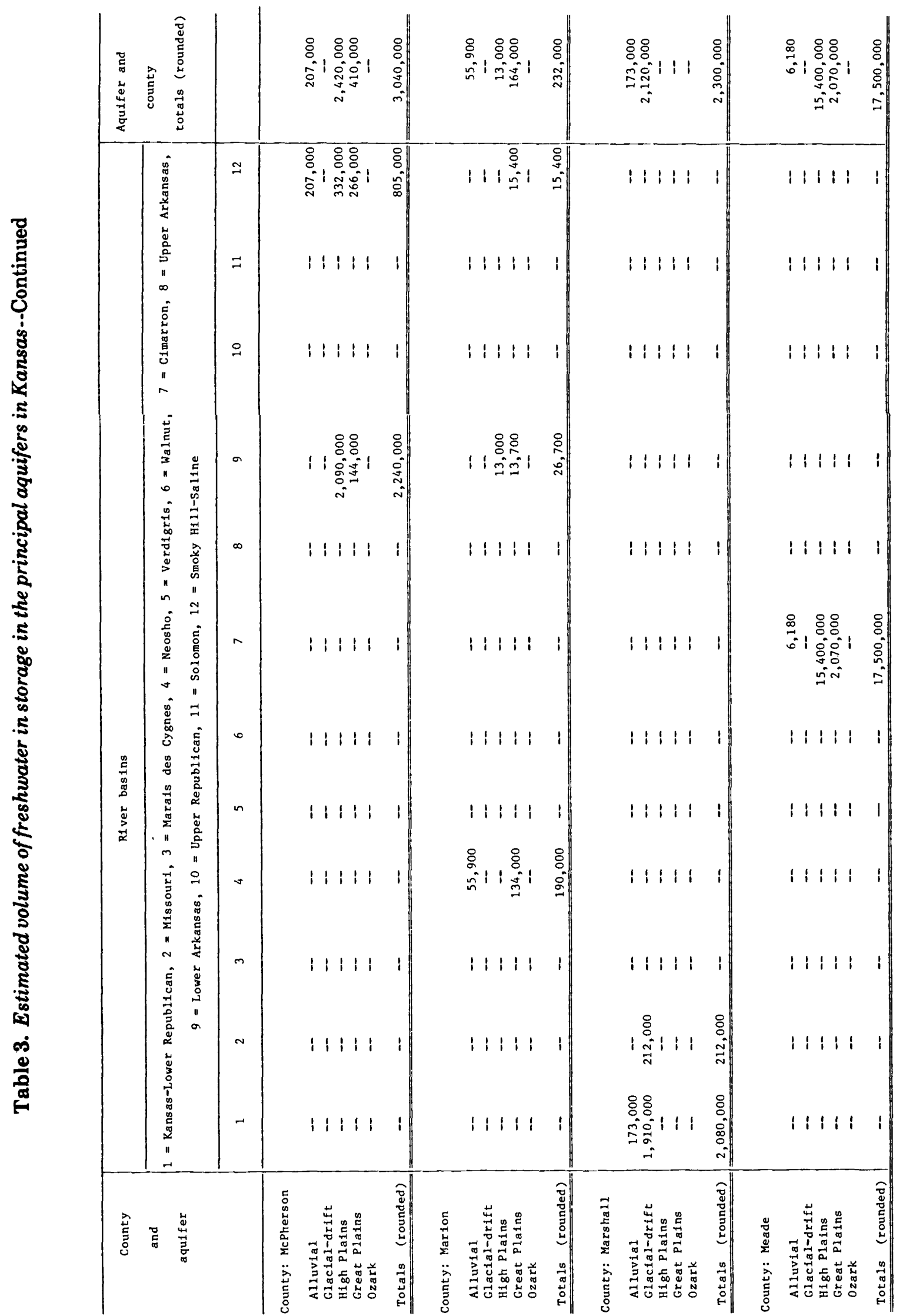




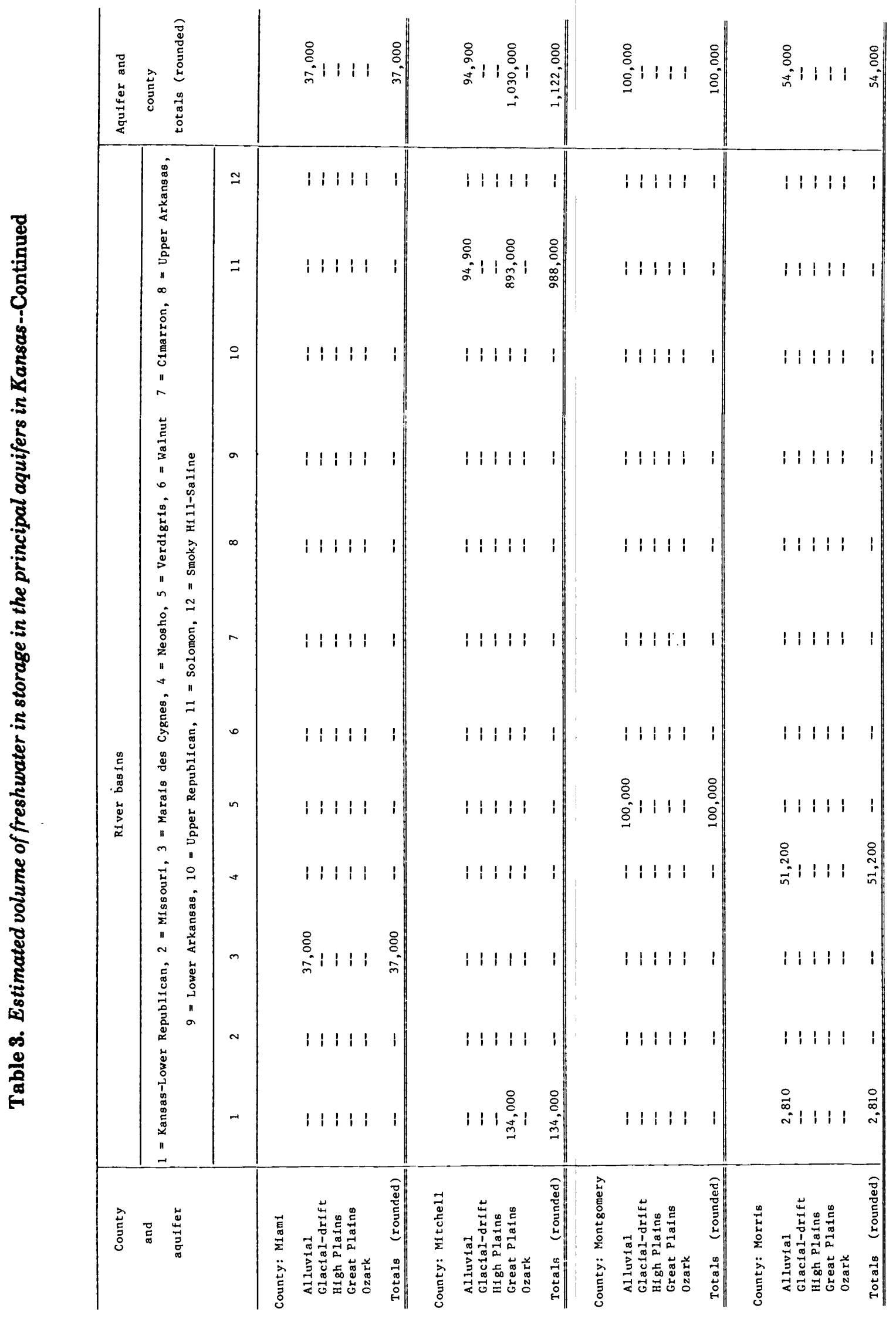




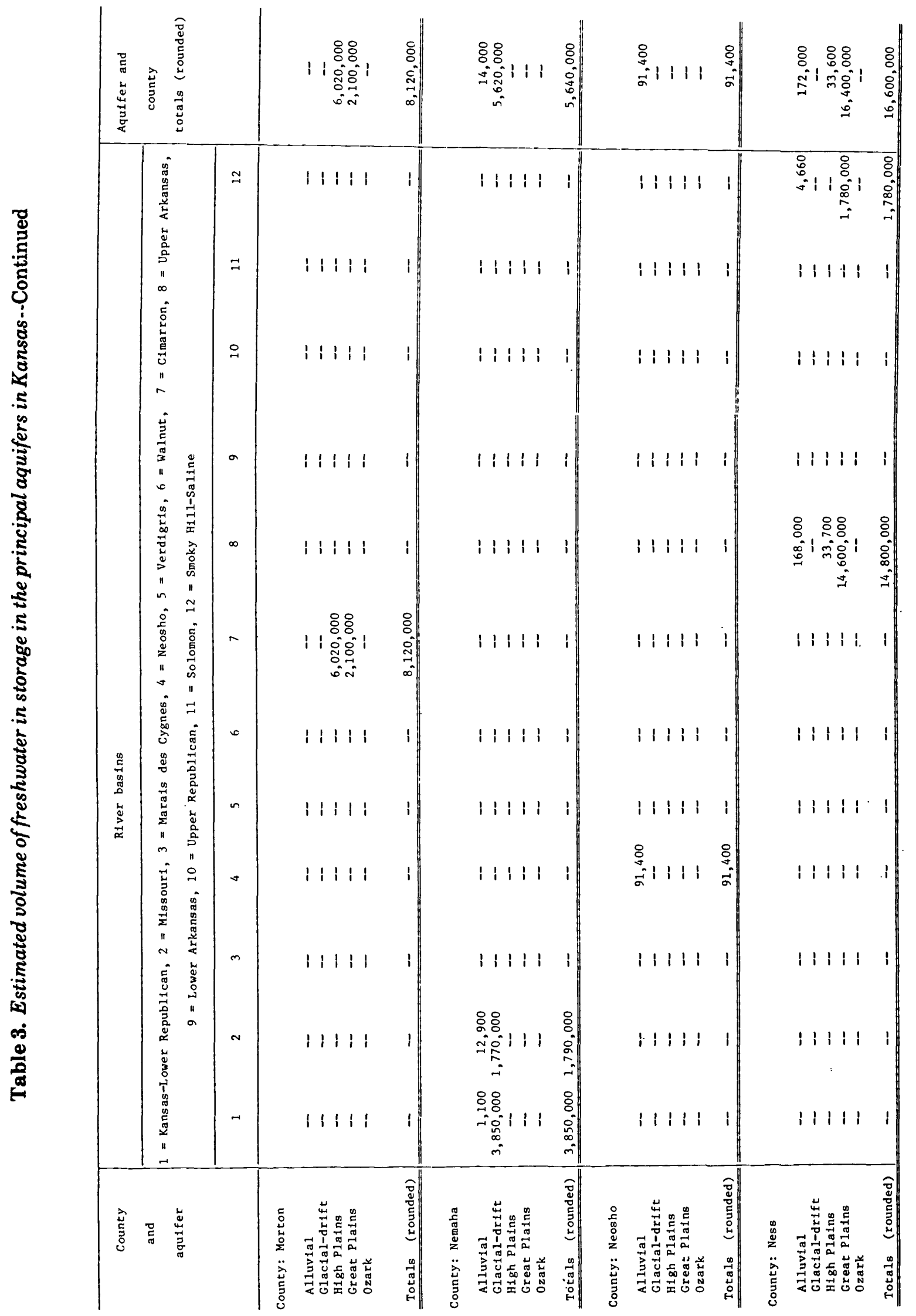




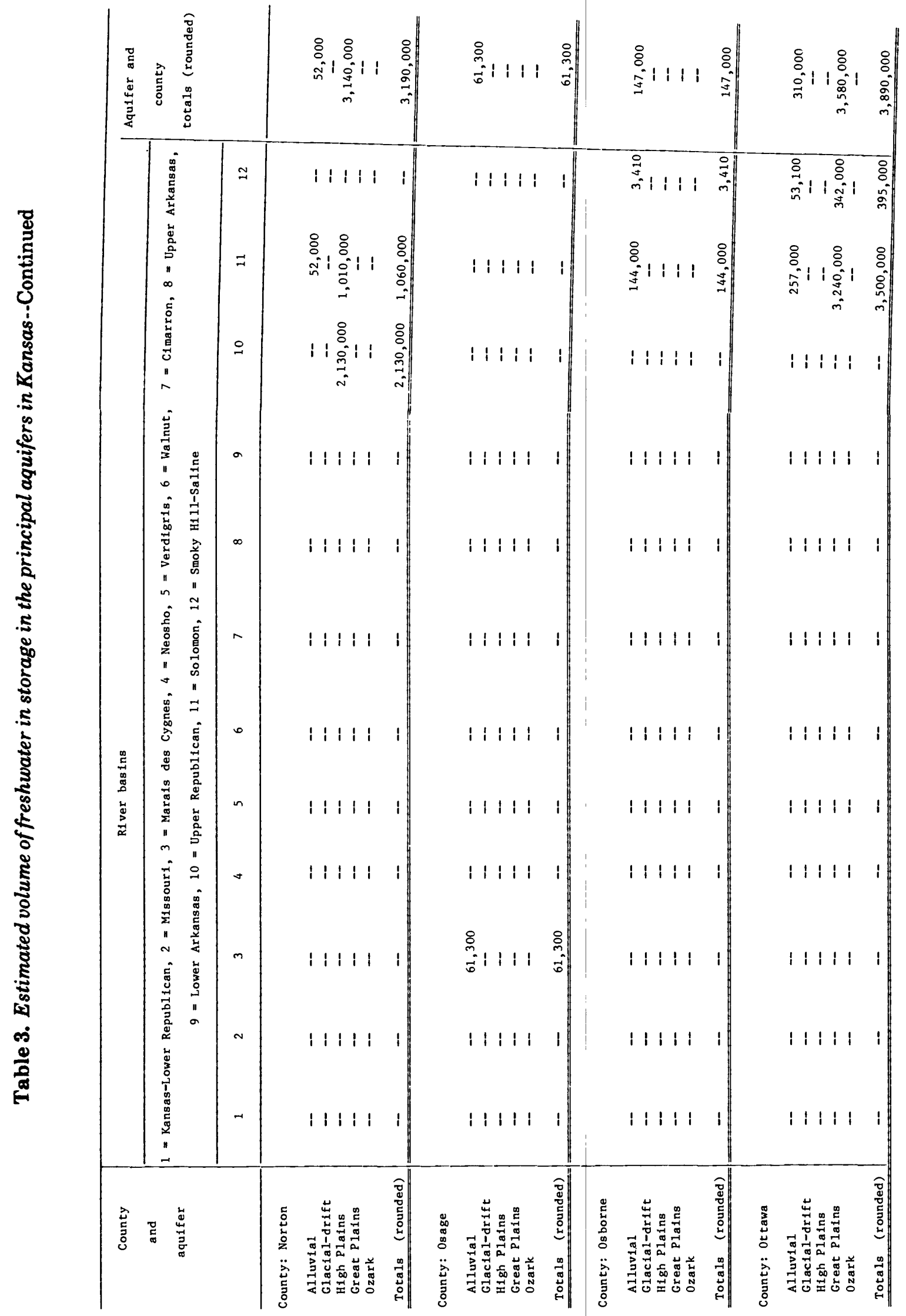




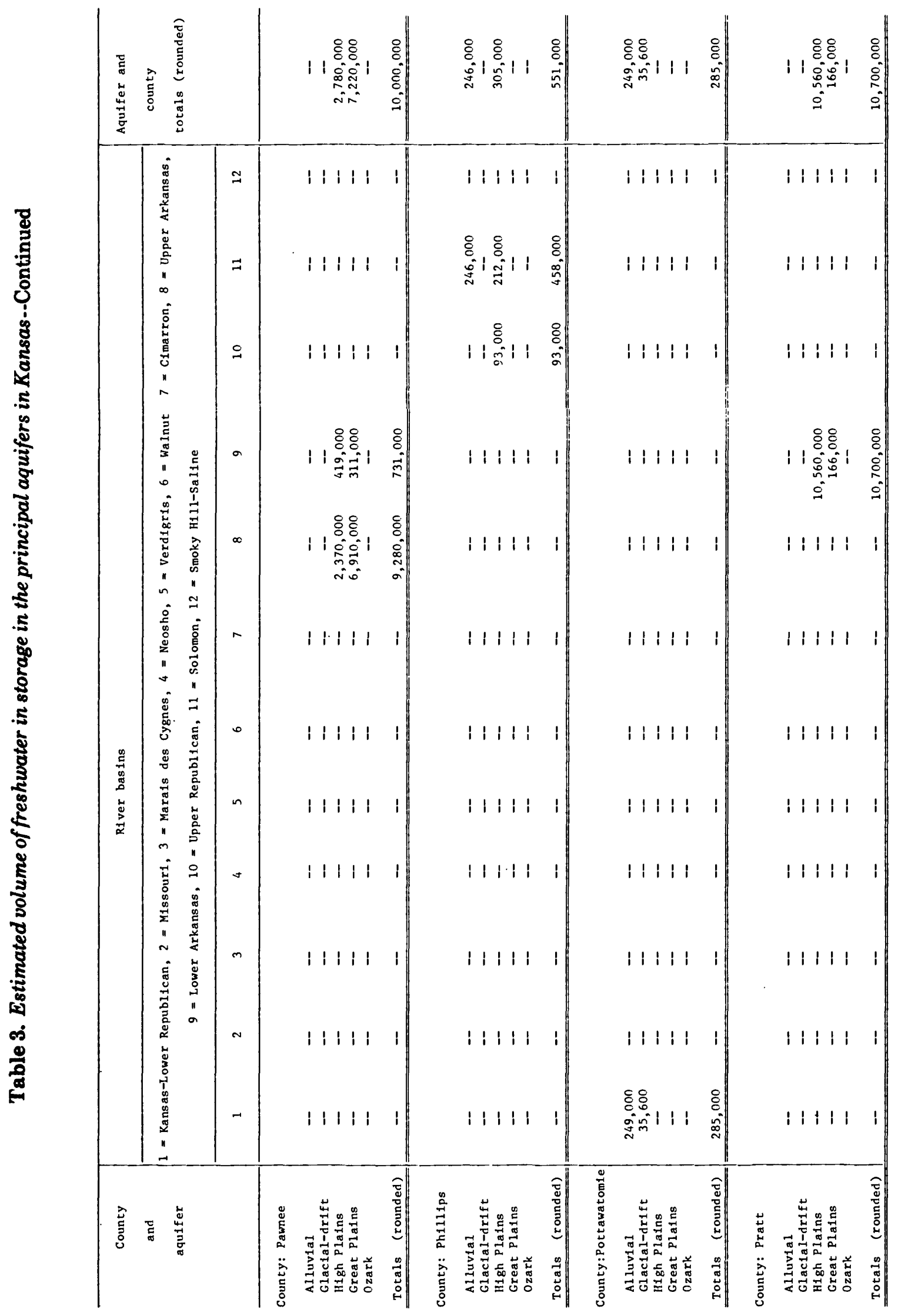

Supplemental Information 


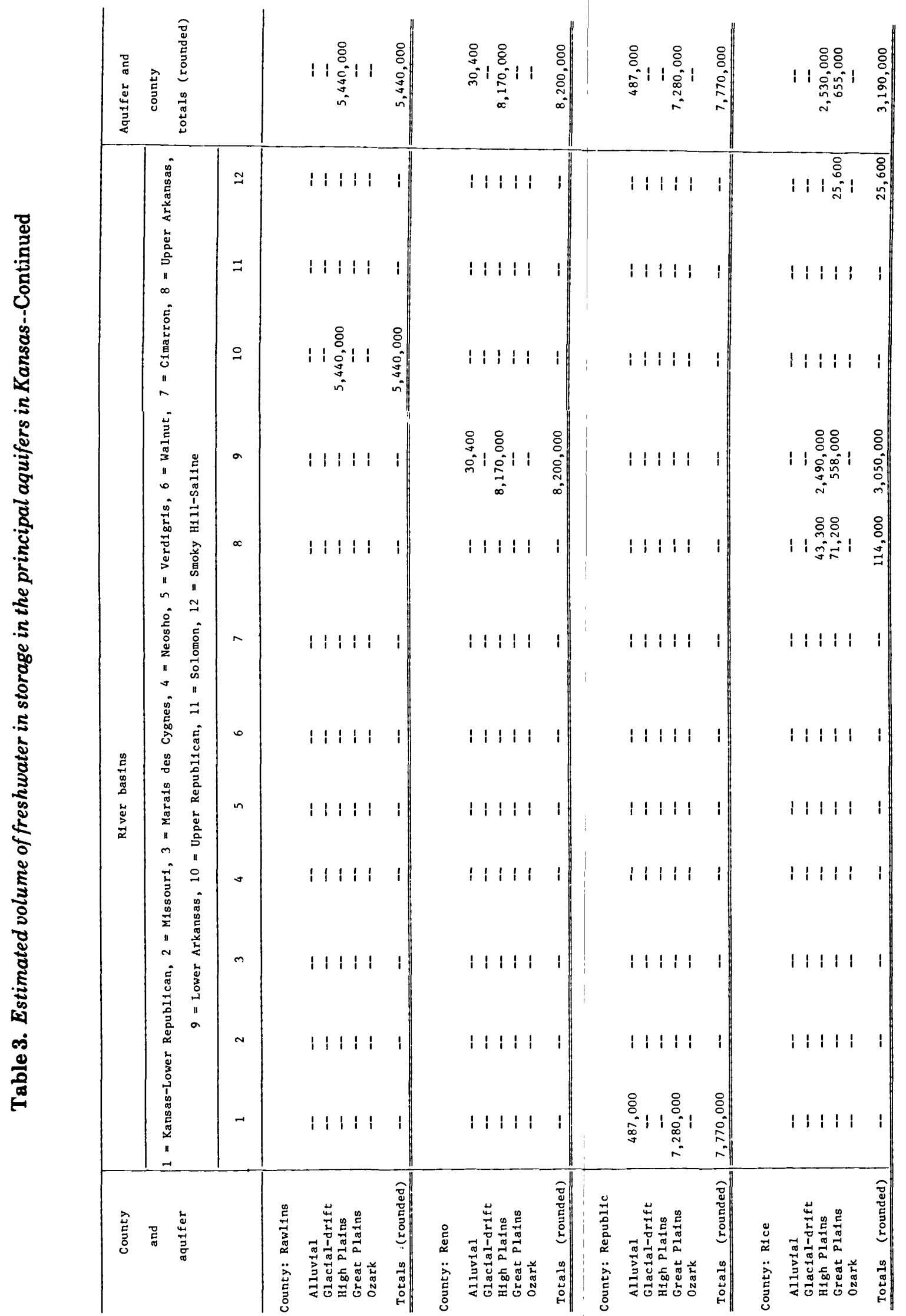




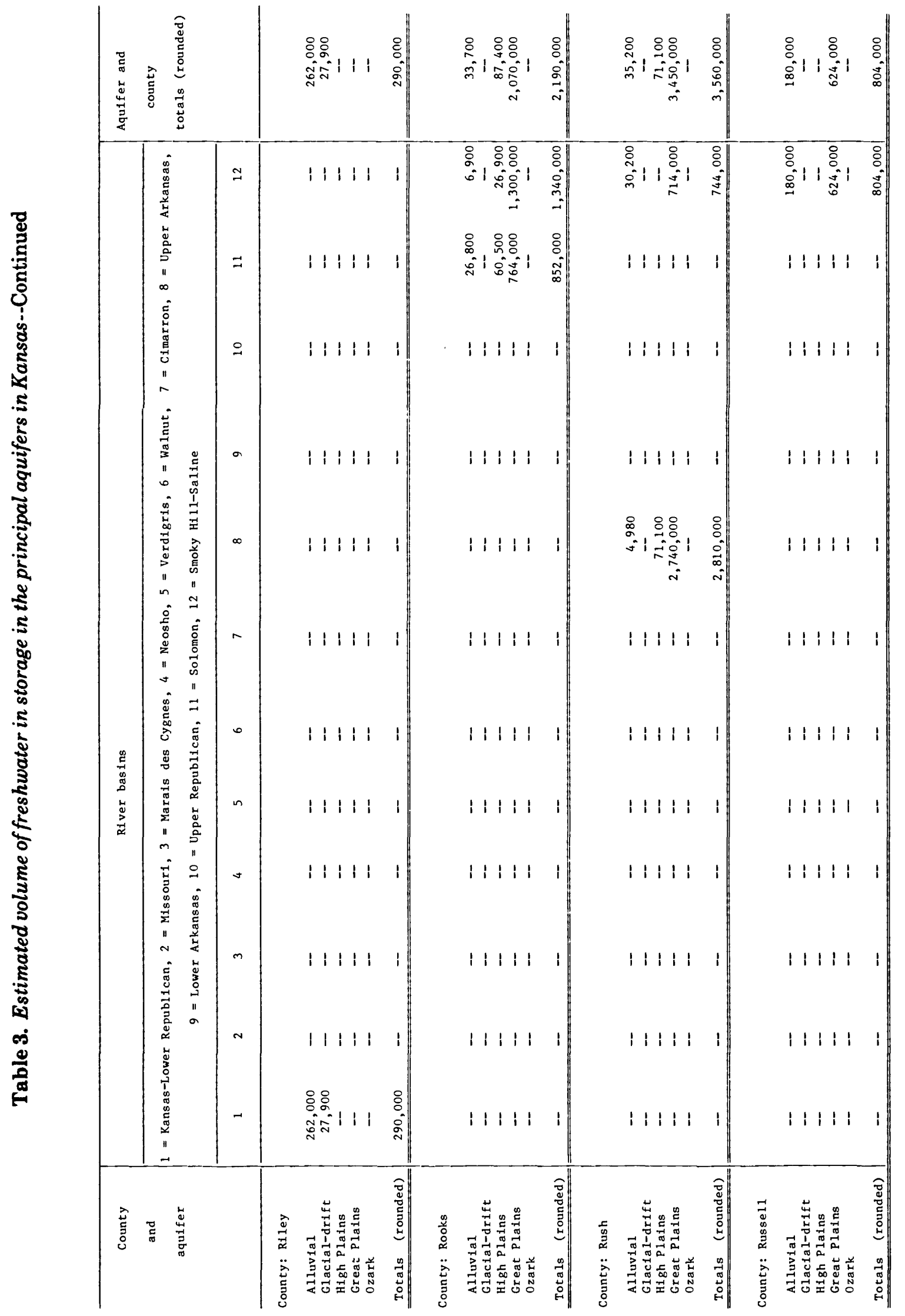




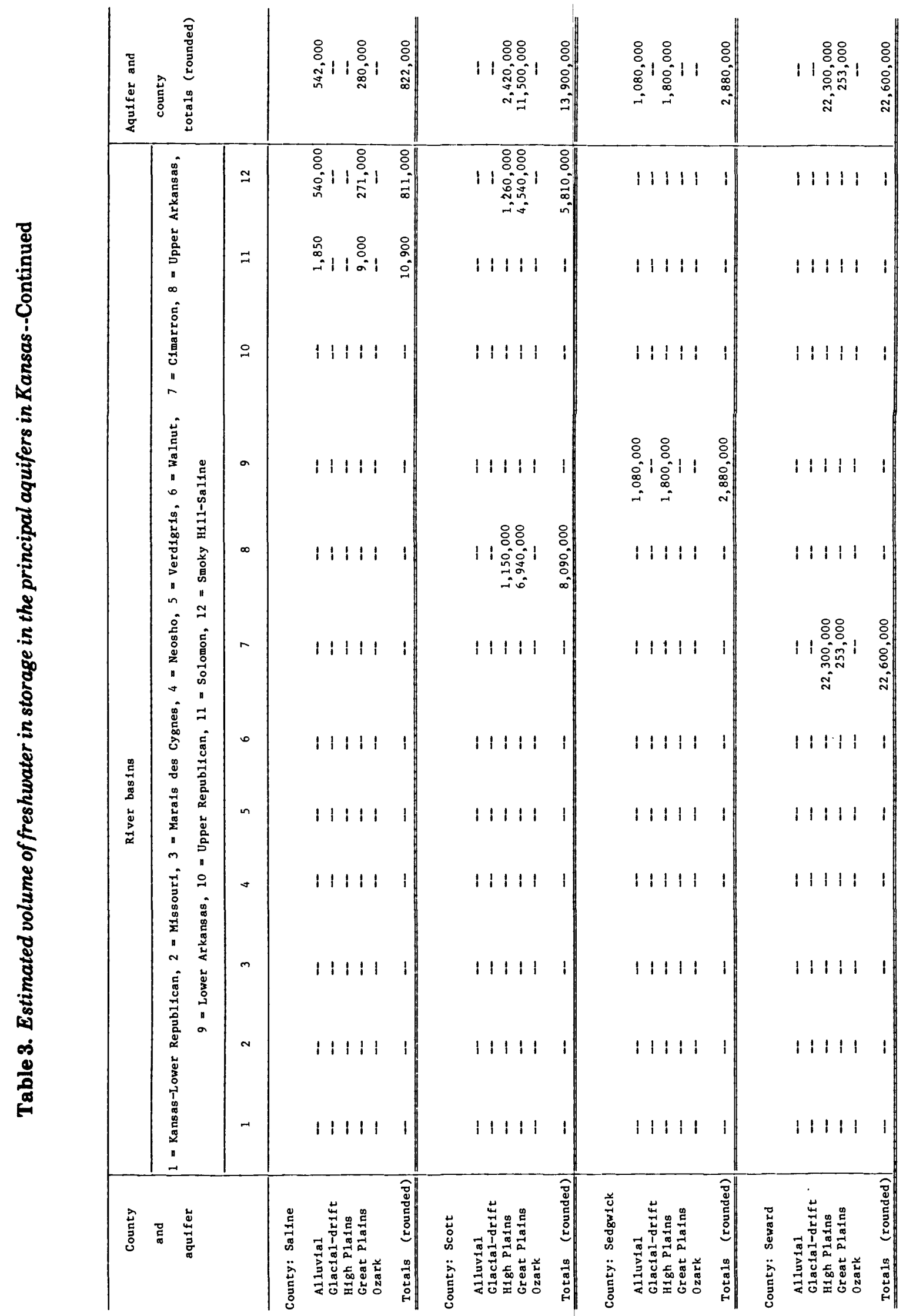




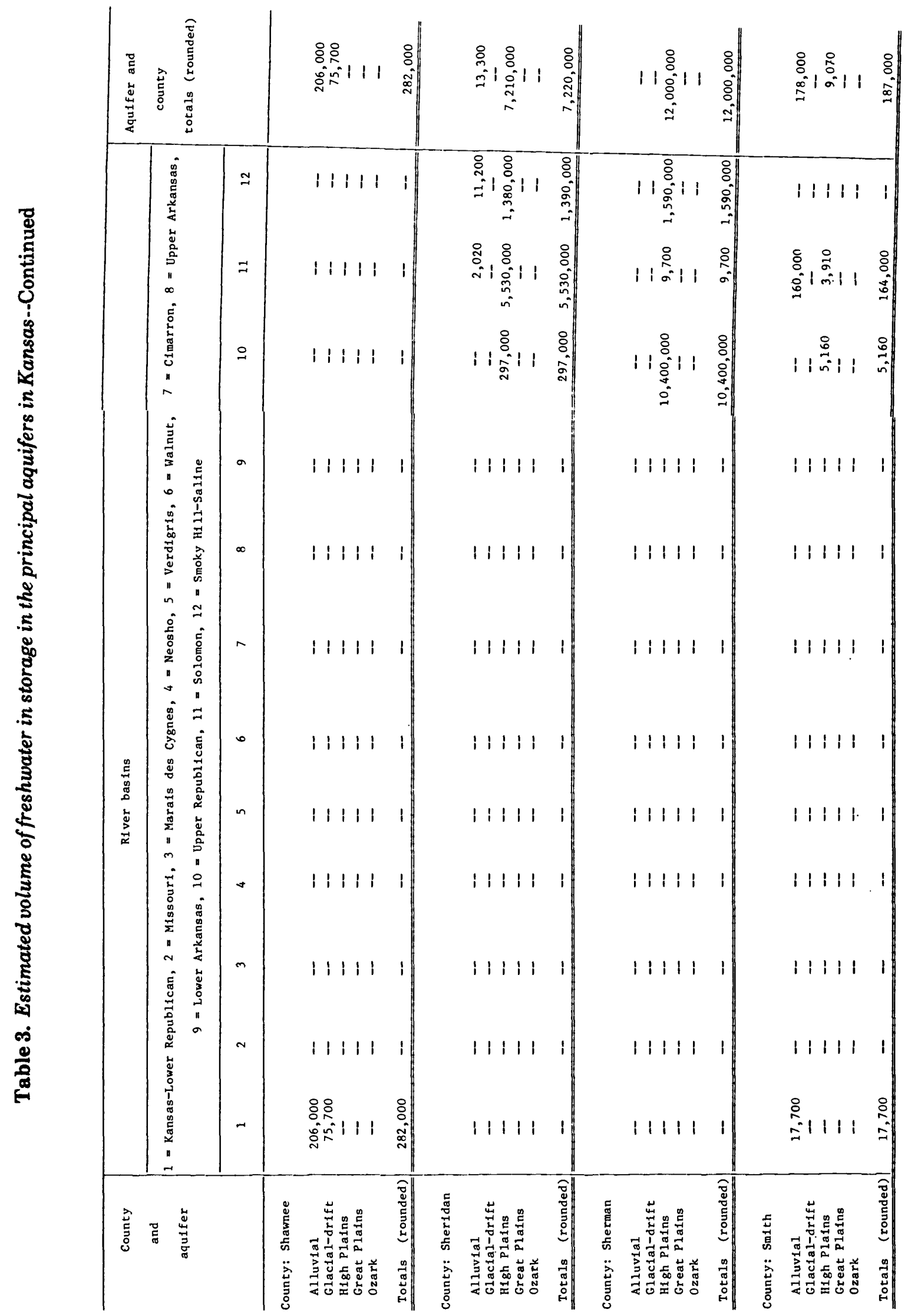




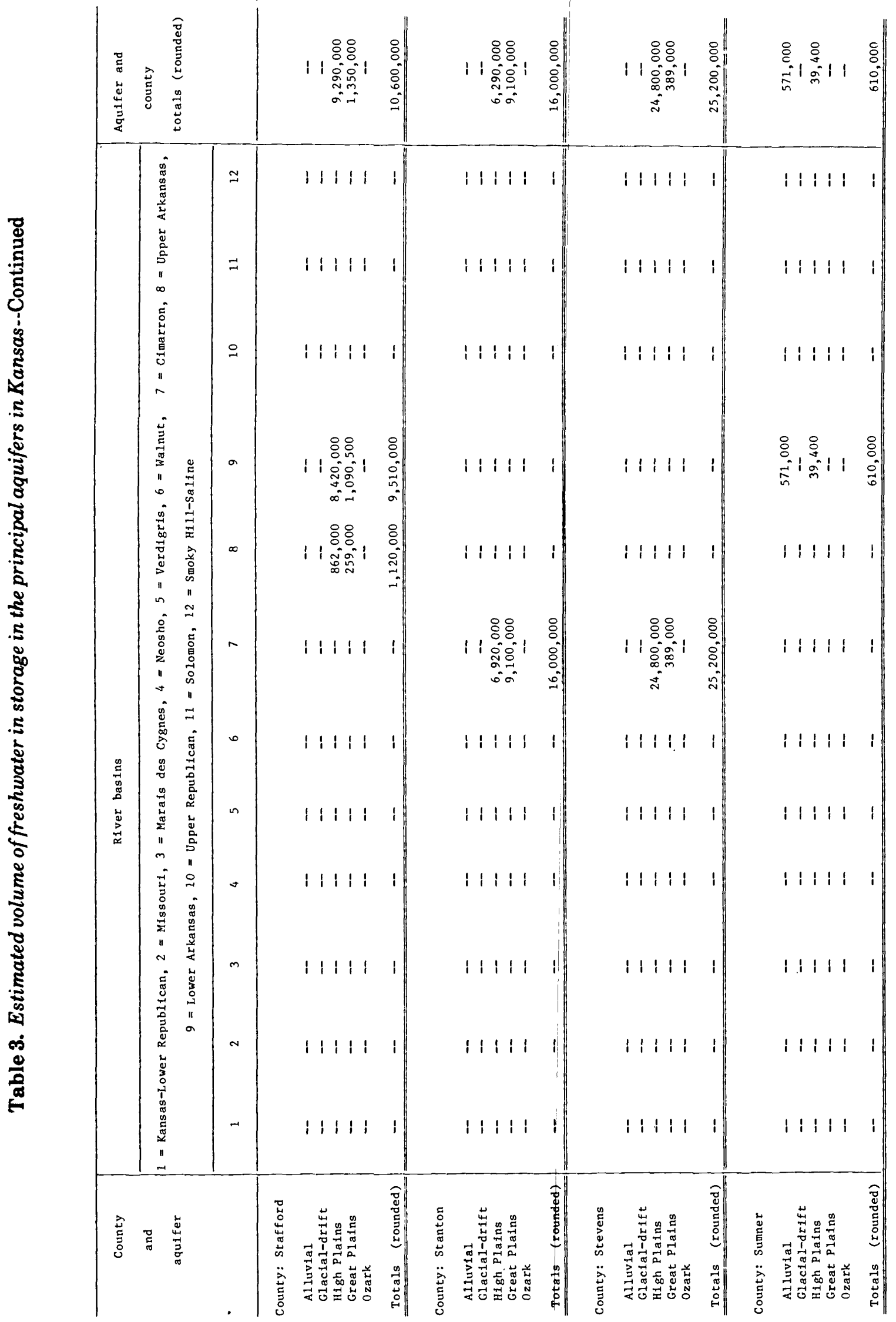




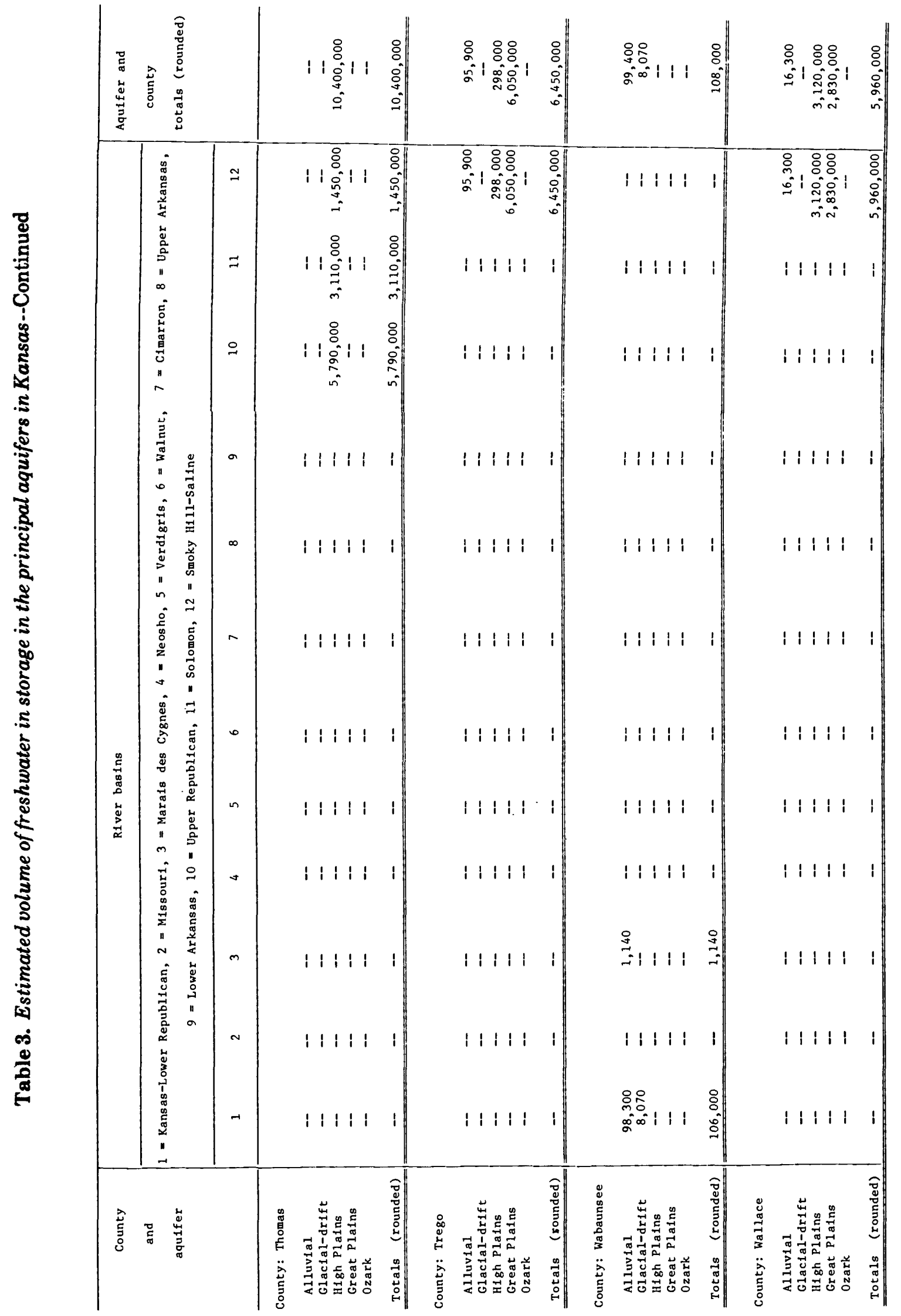




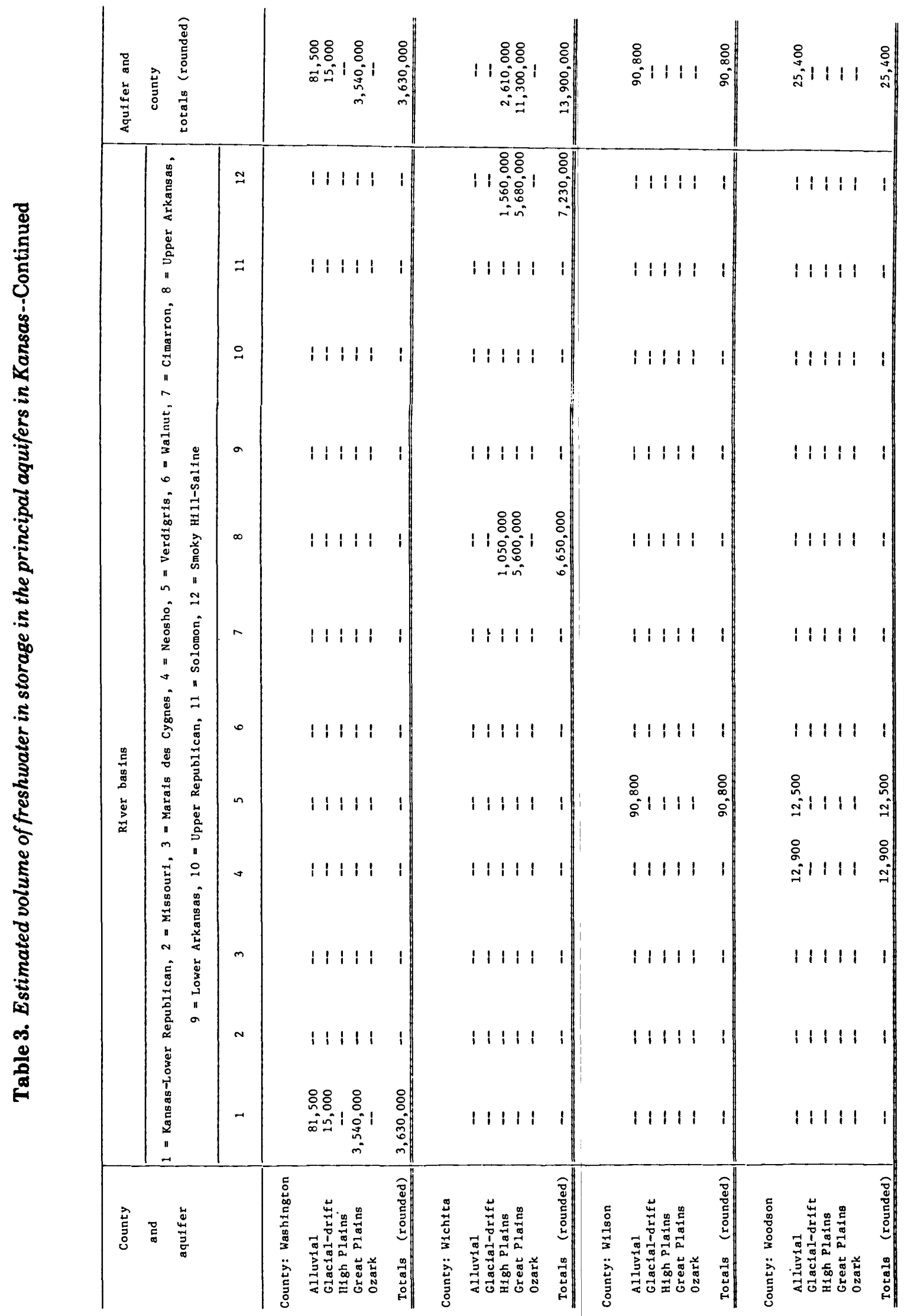




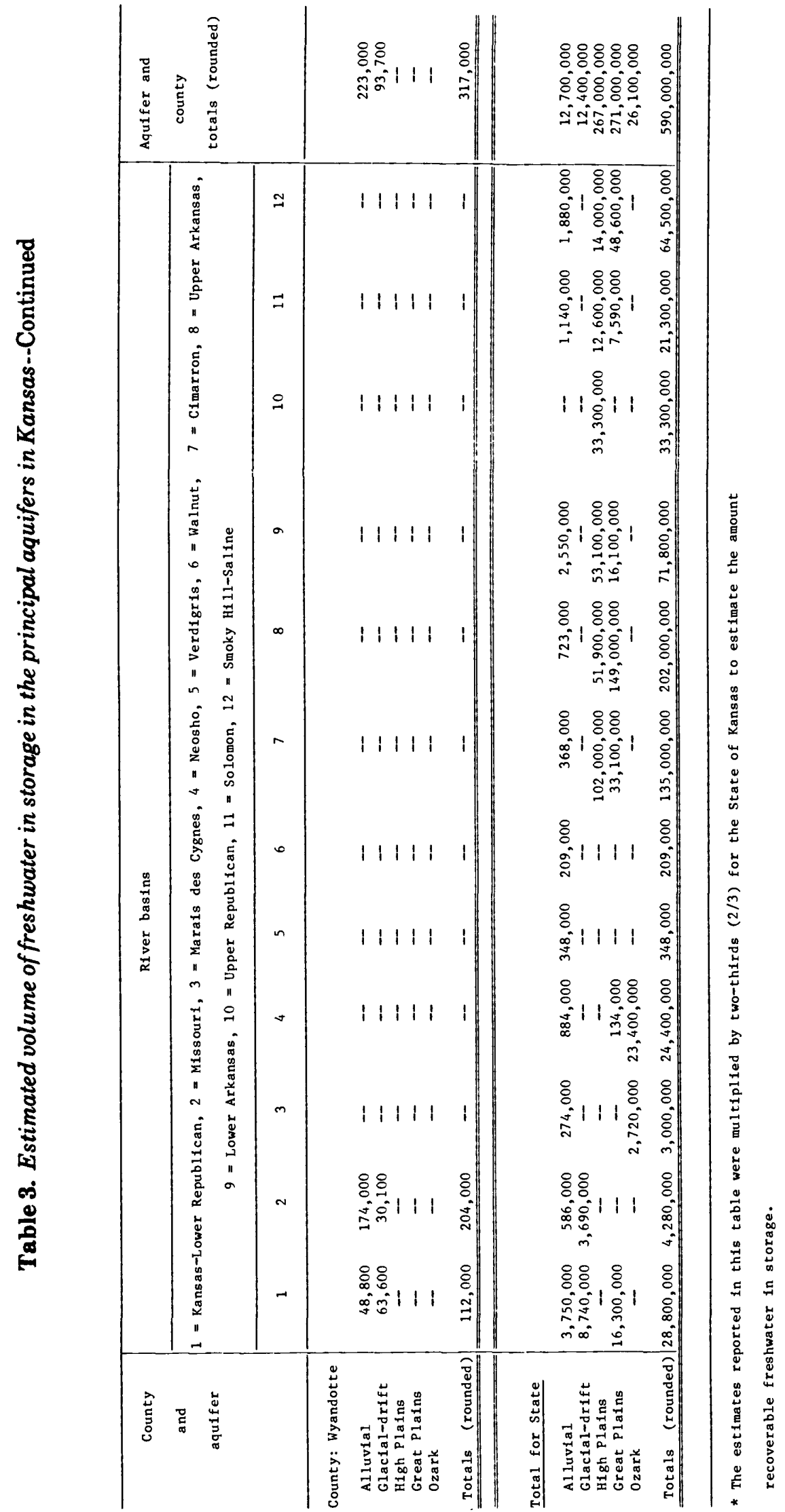




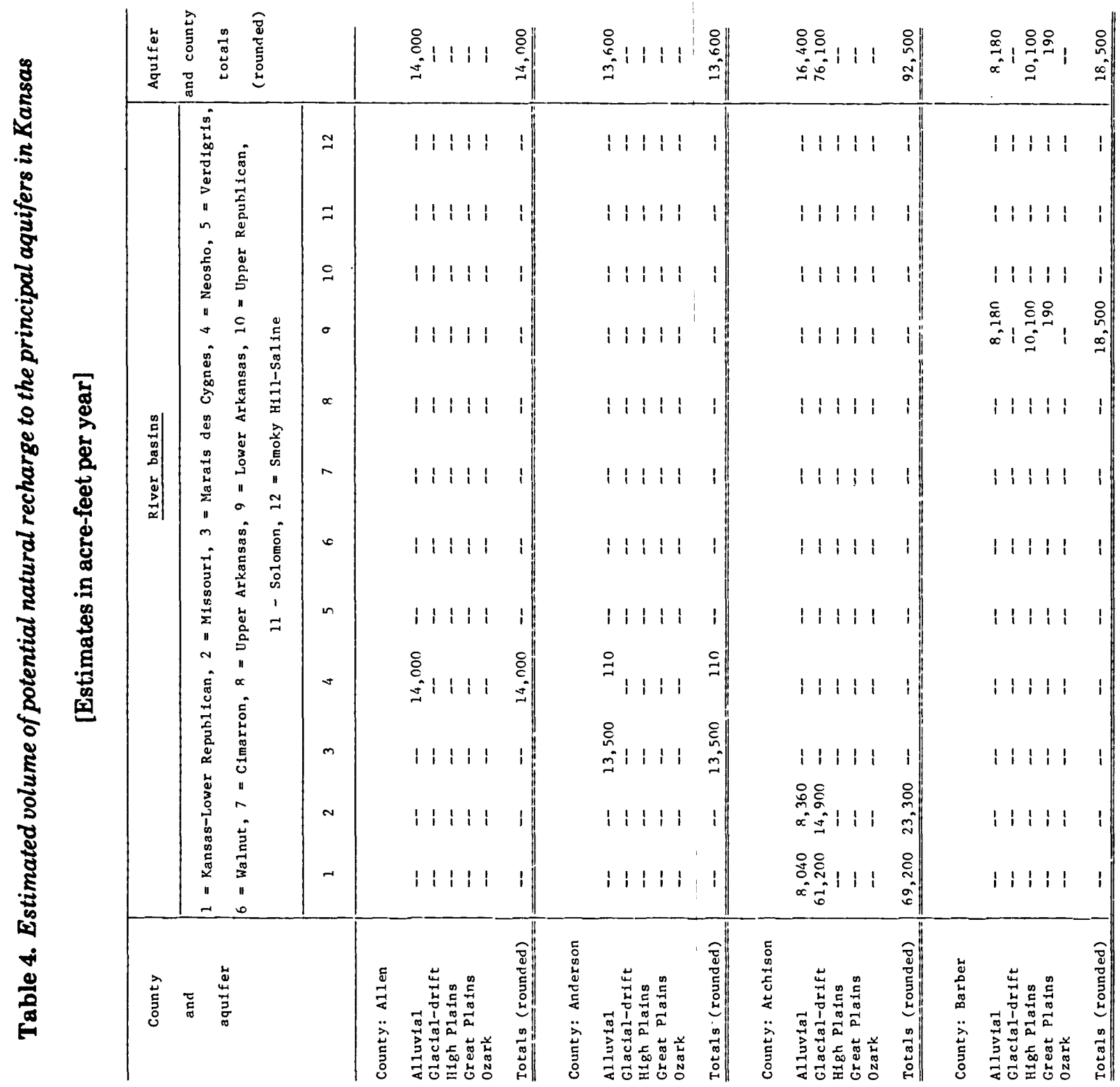




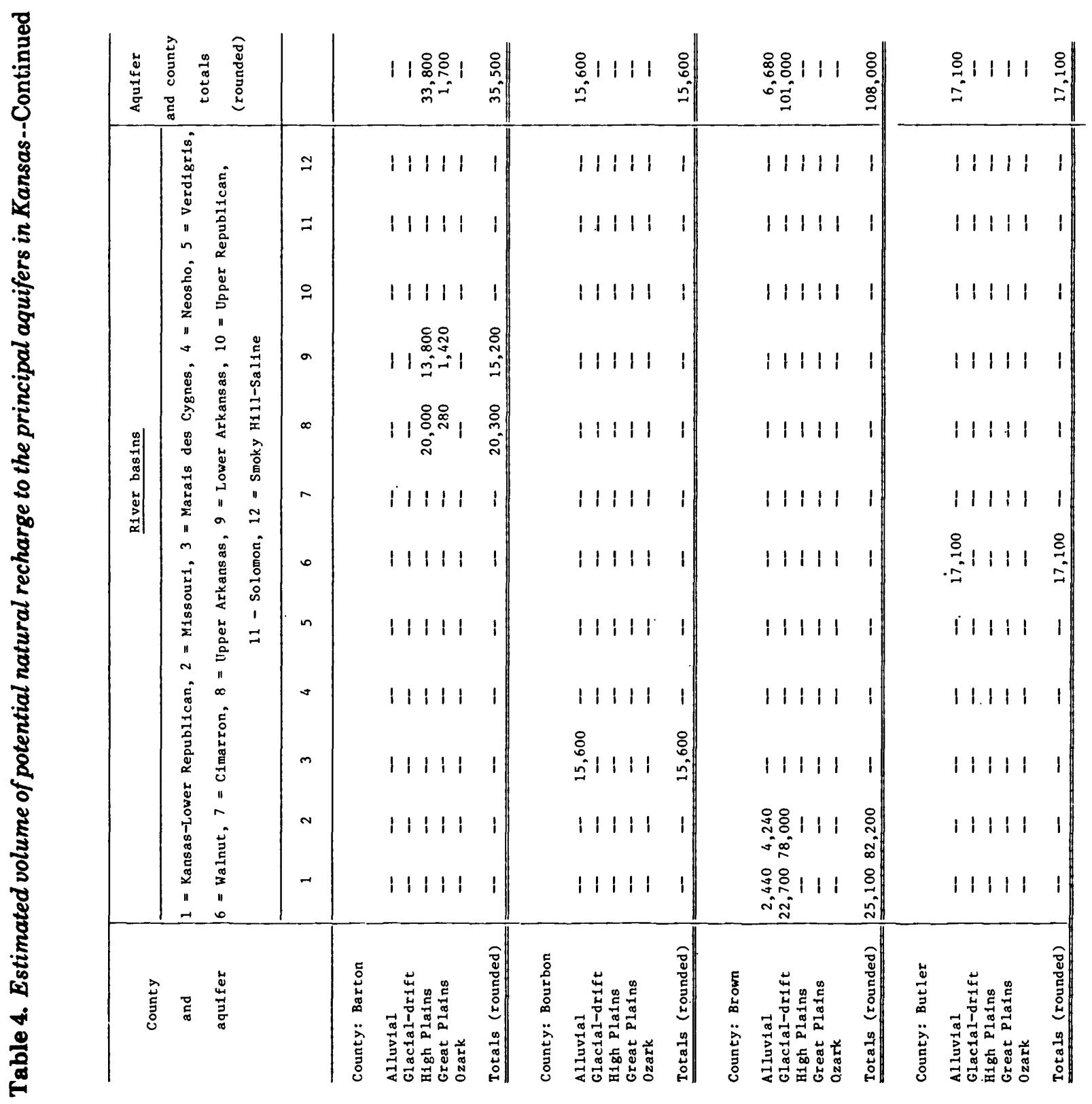




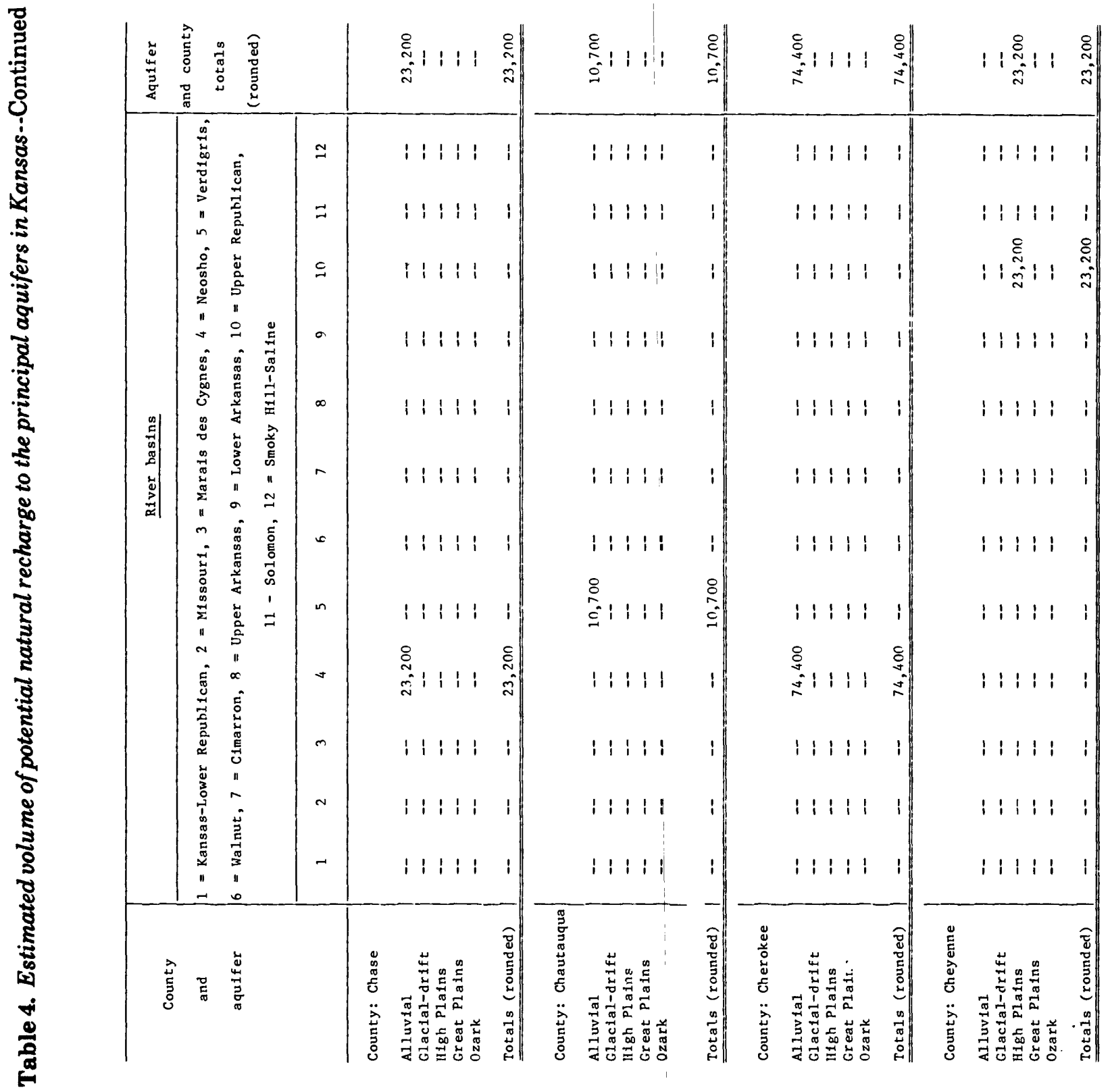




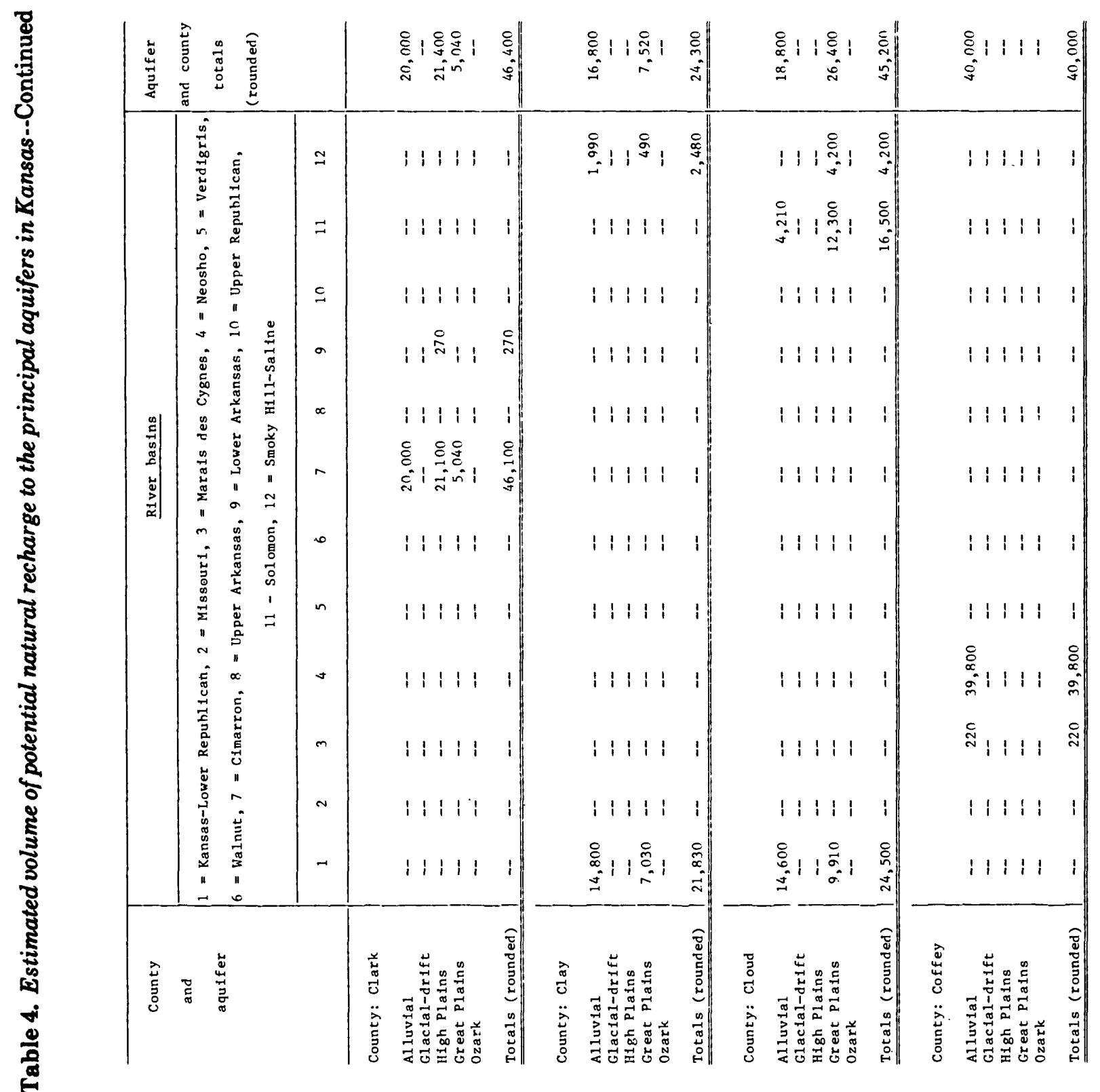




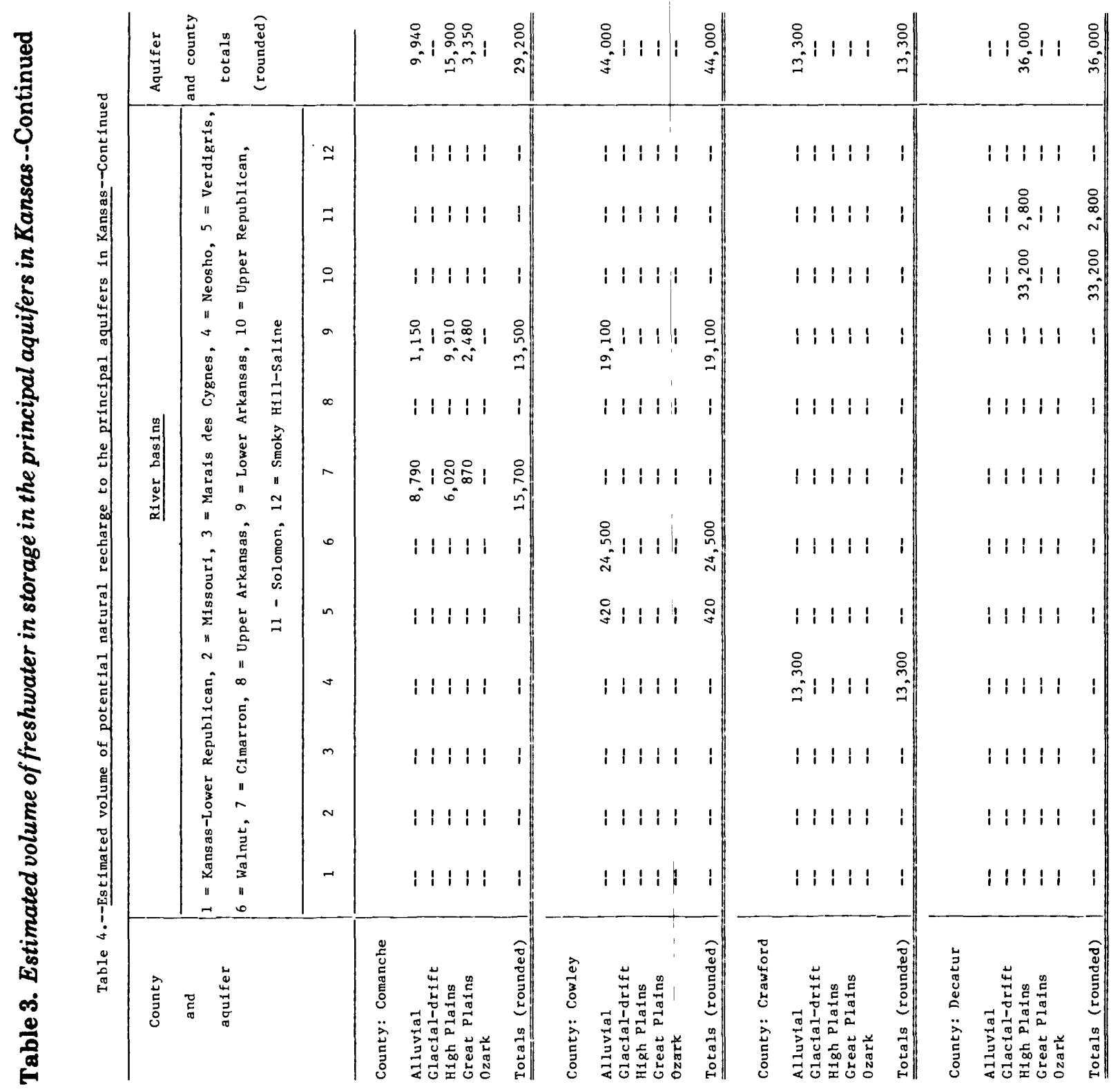




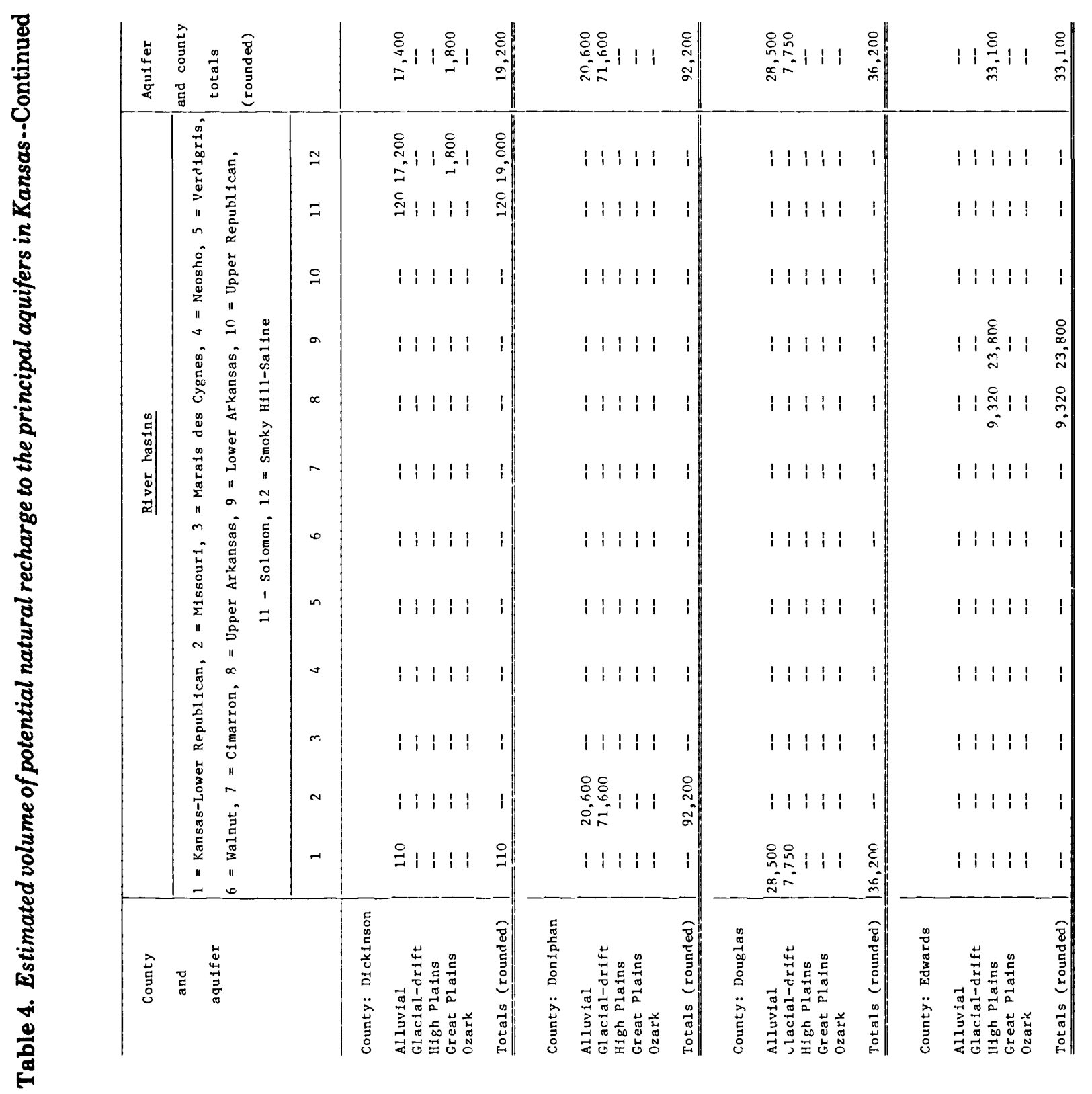




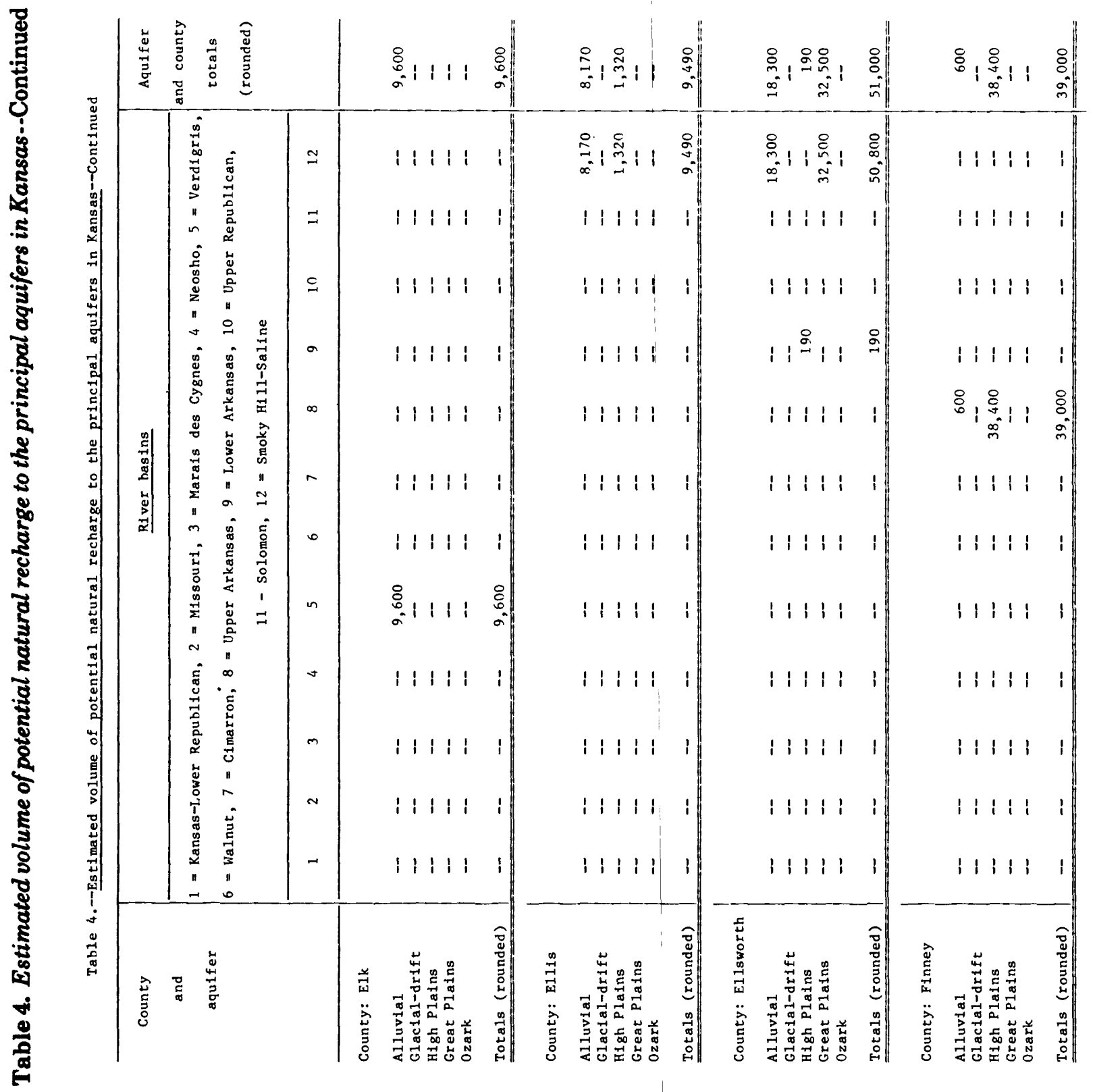




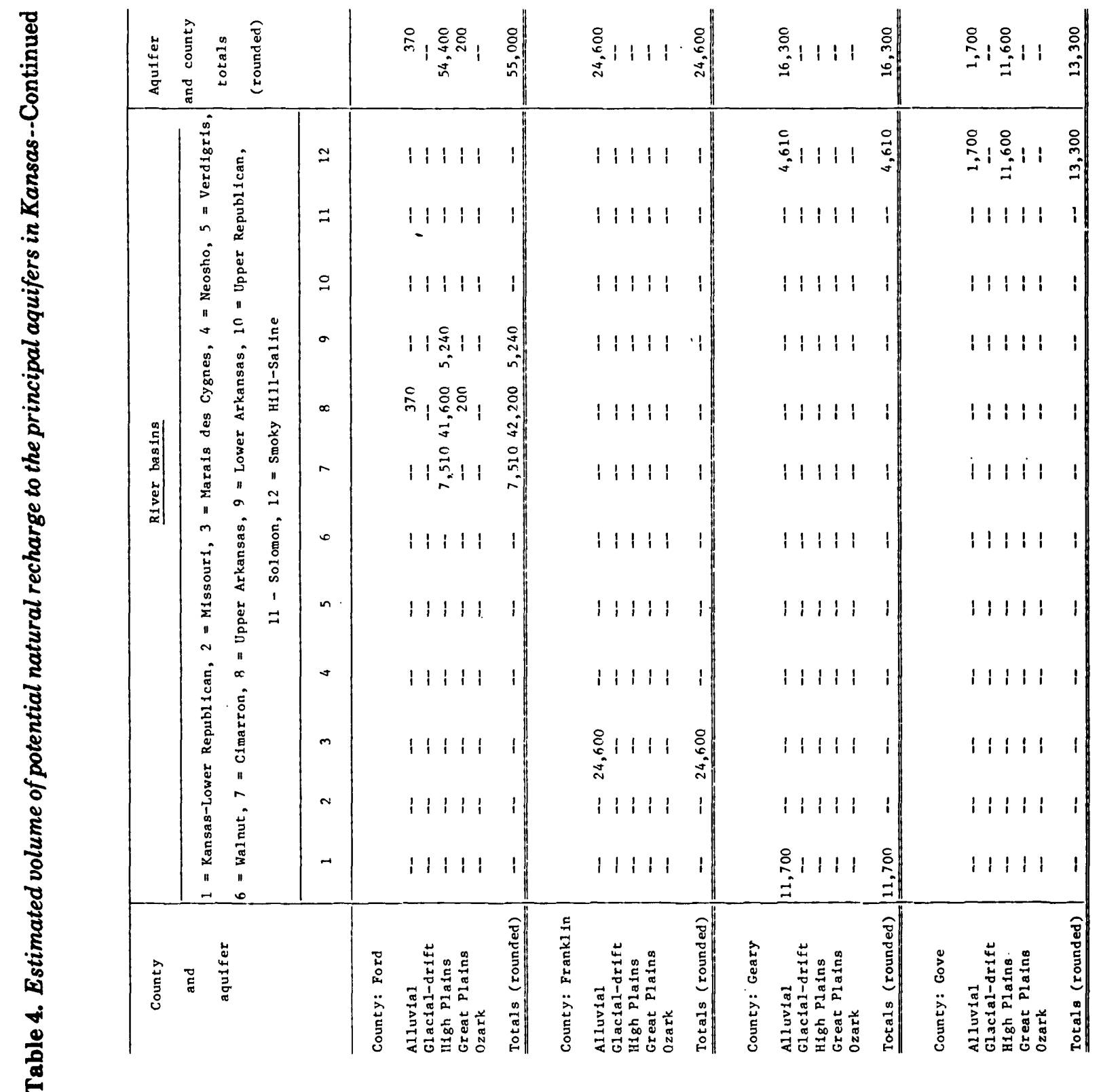




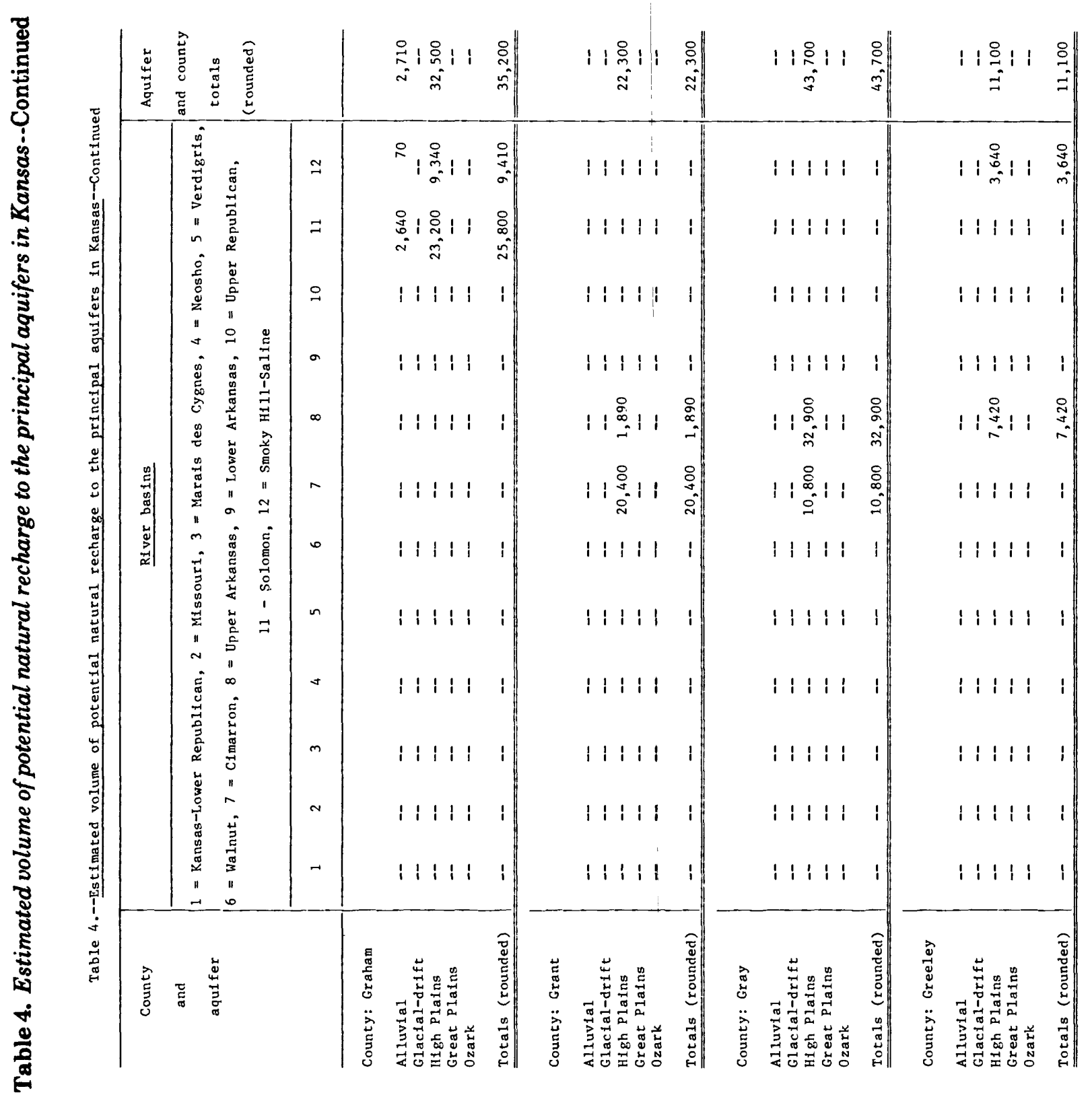




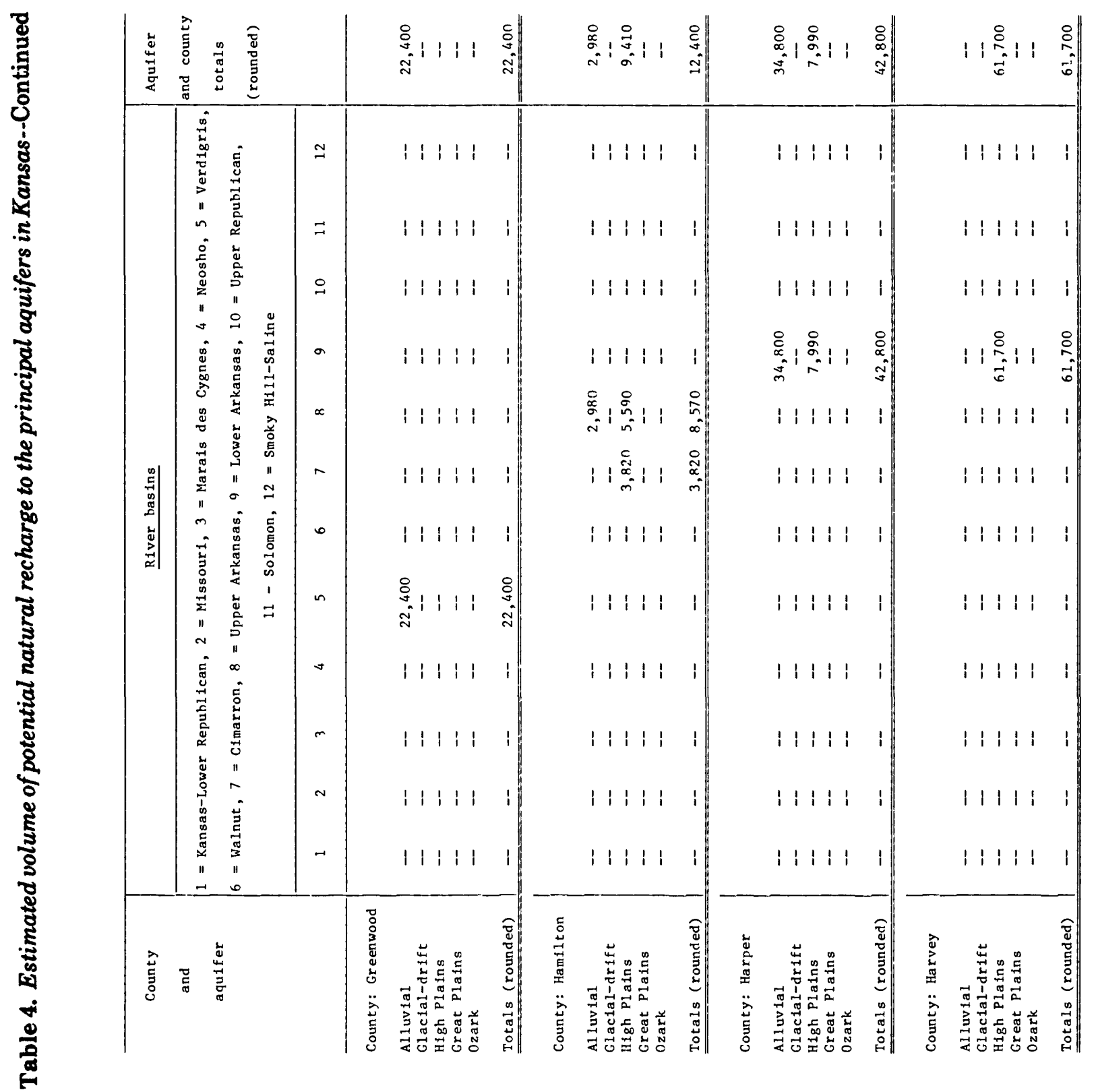




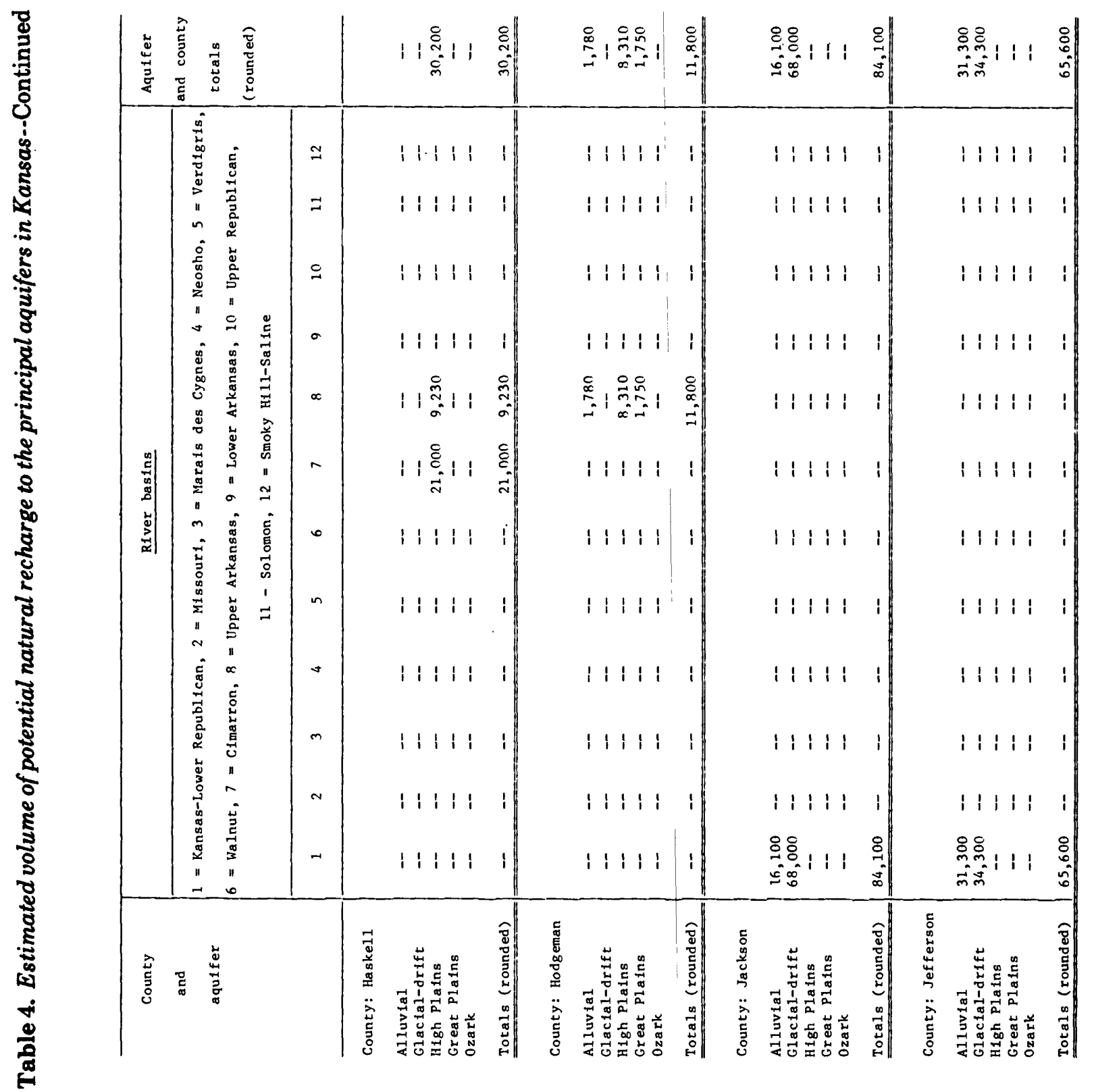




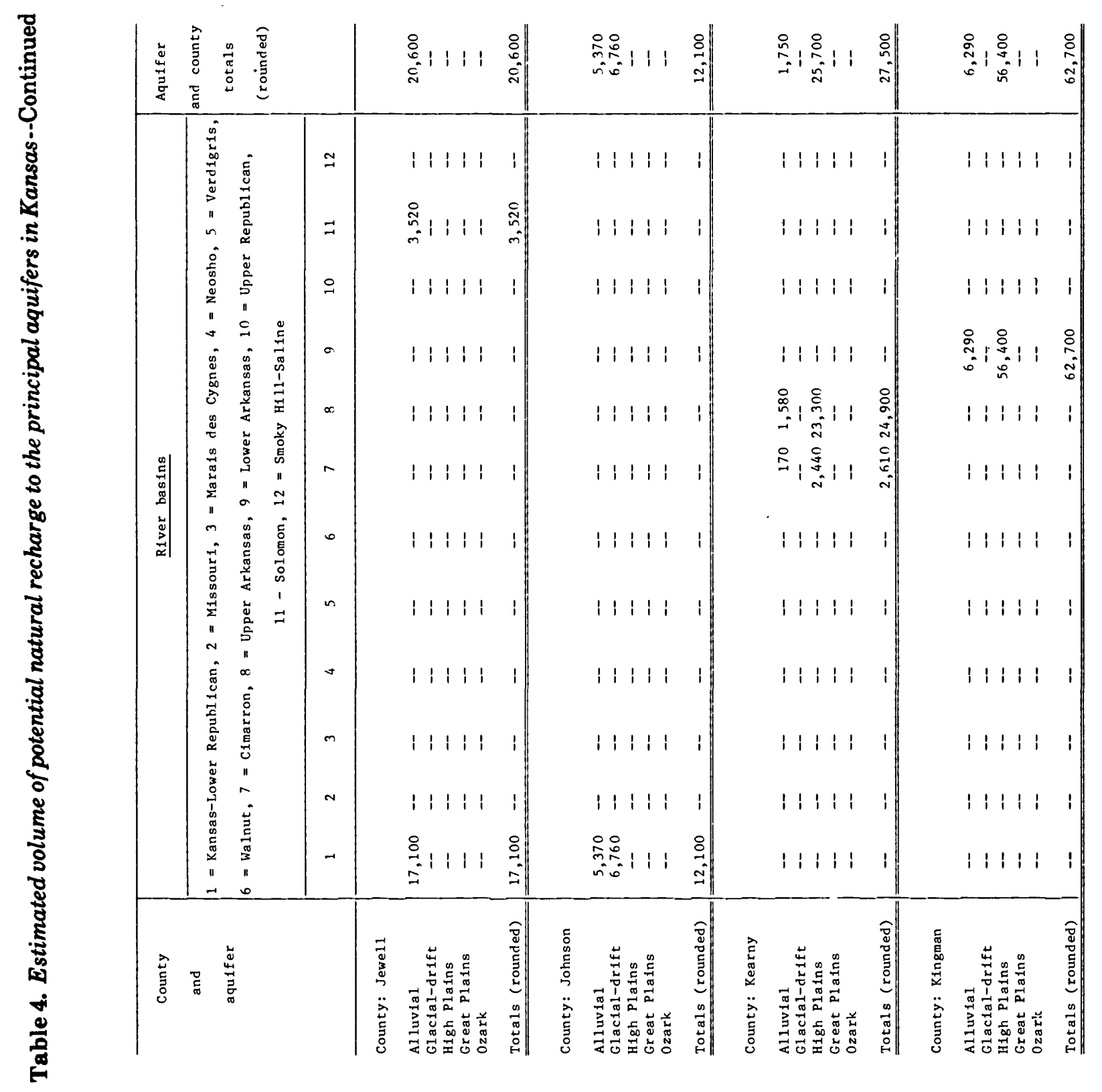




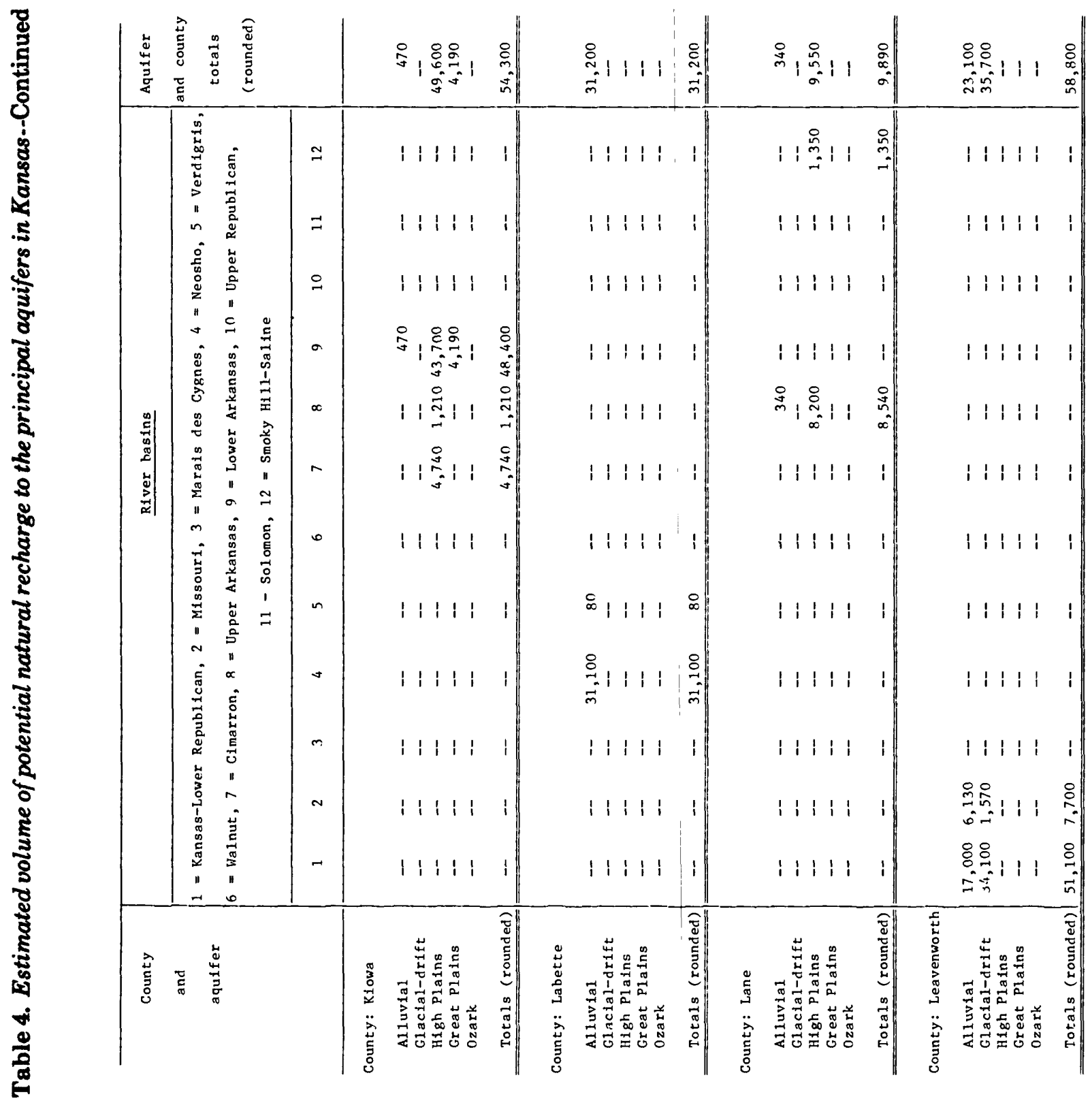




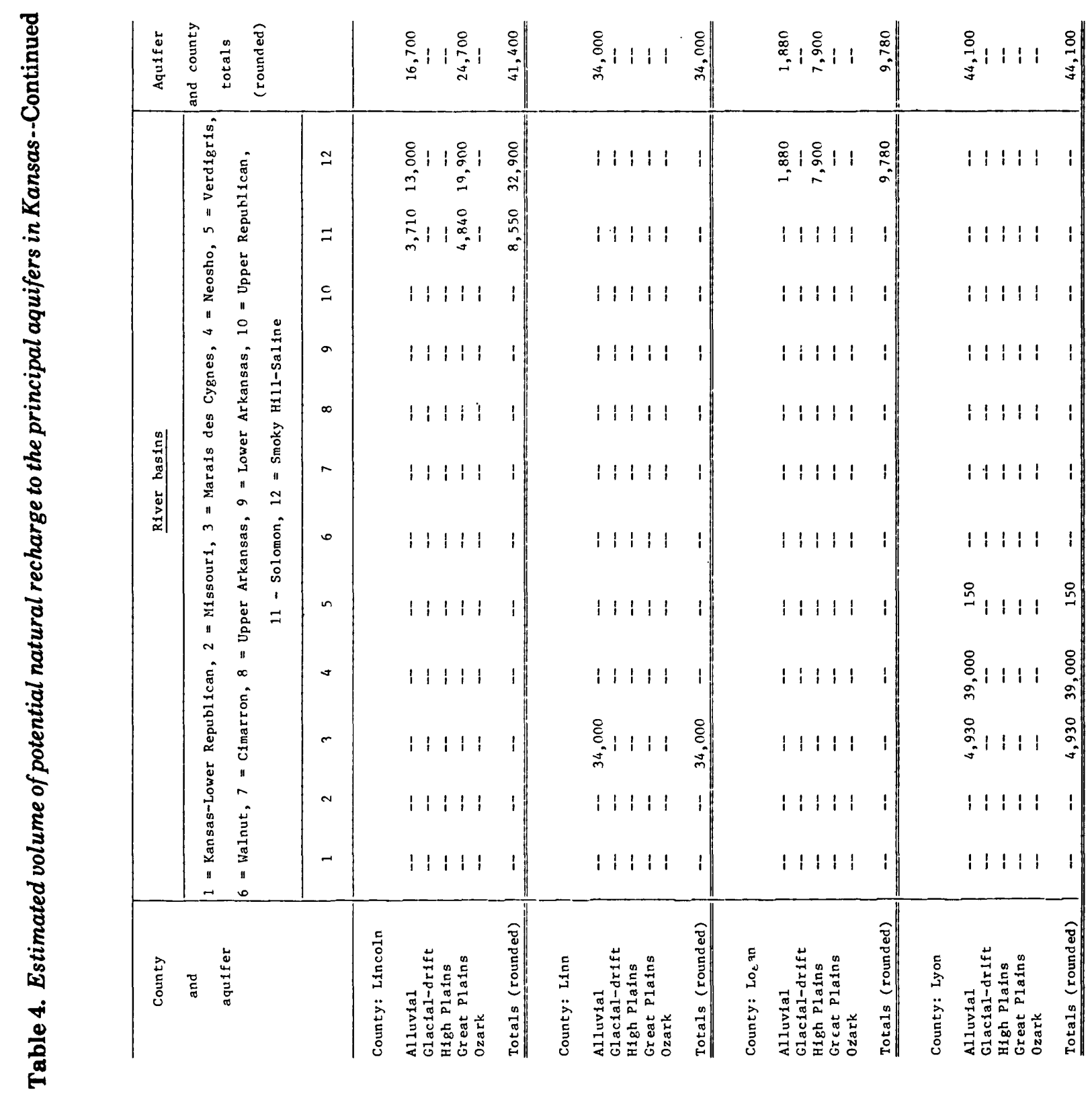




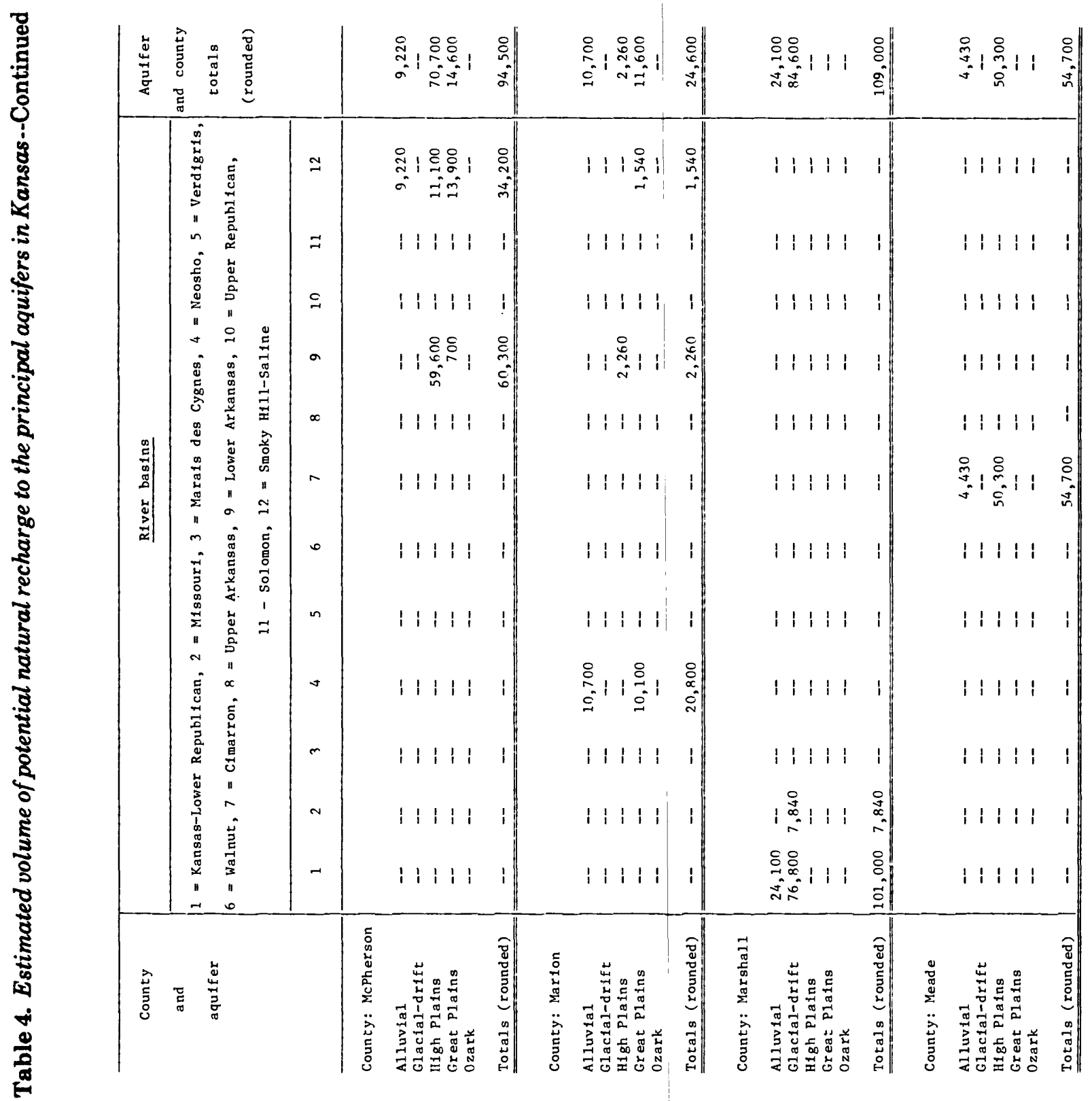




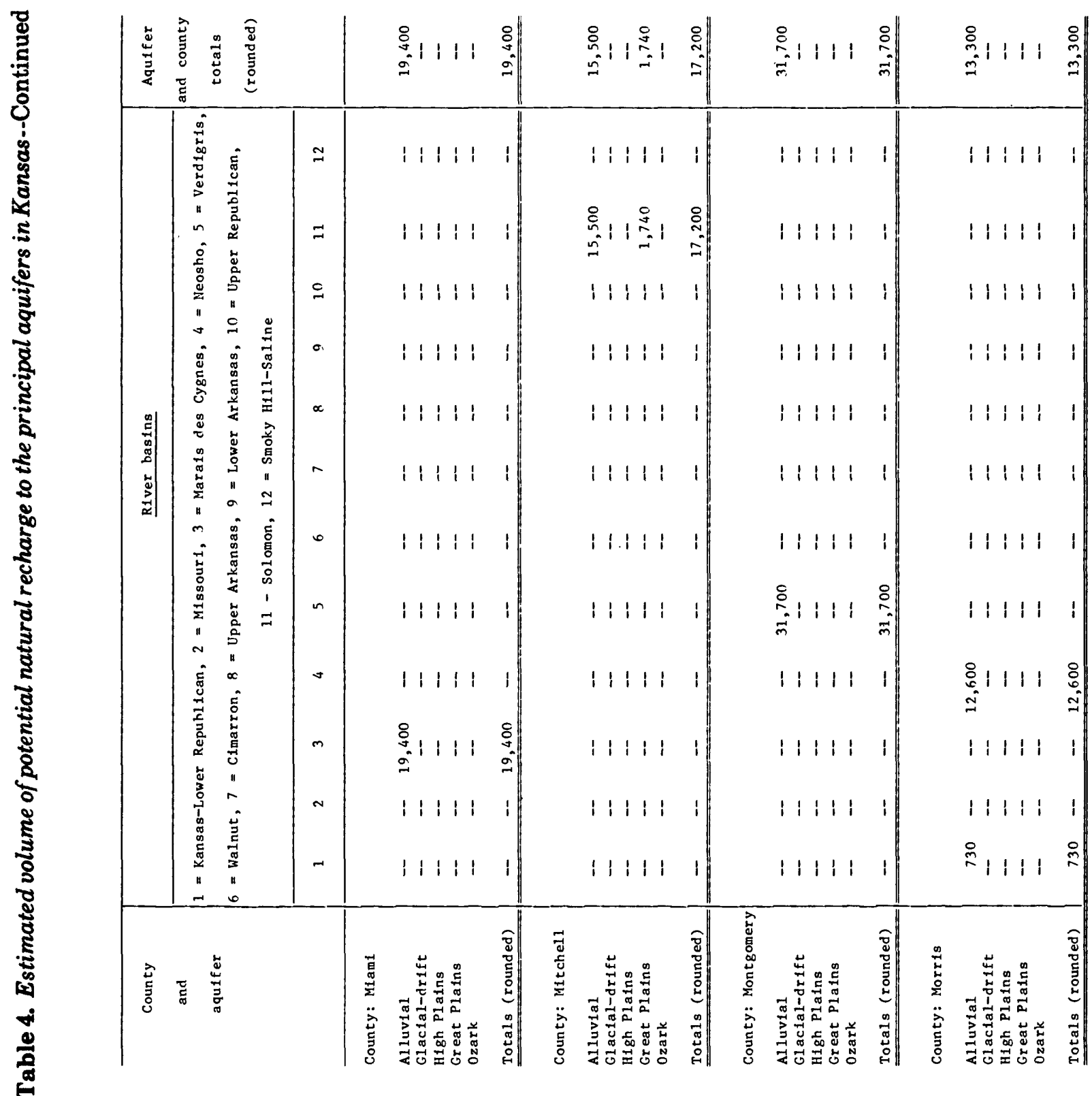




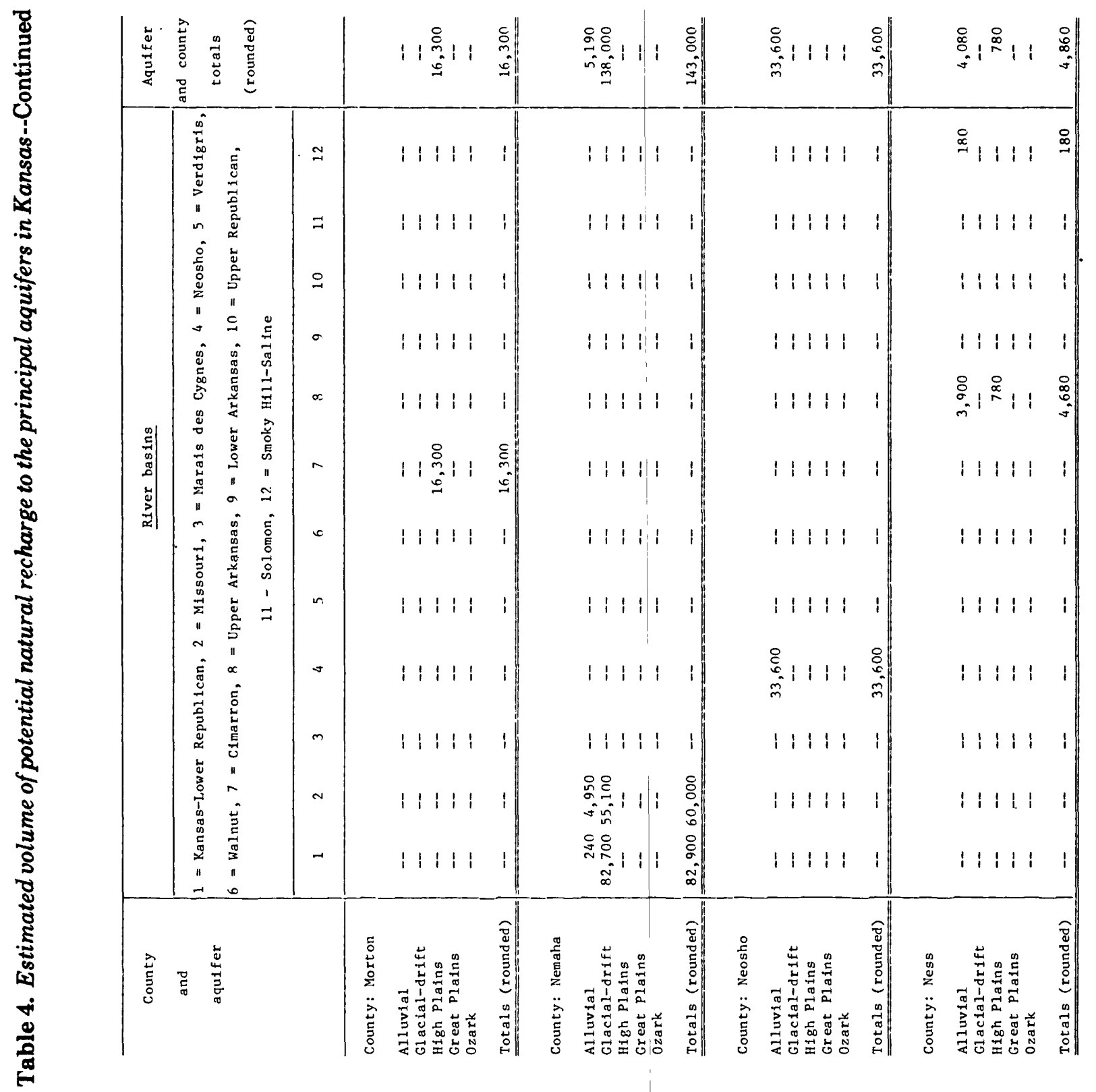




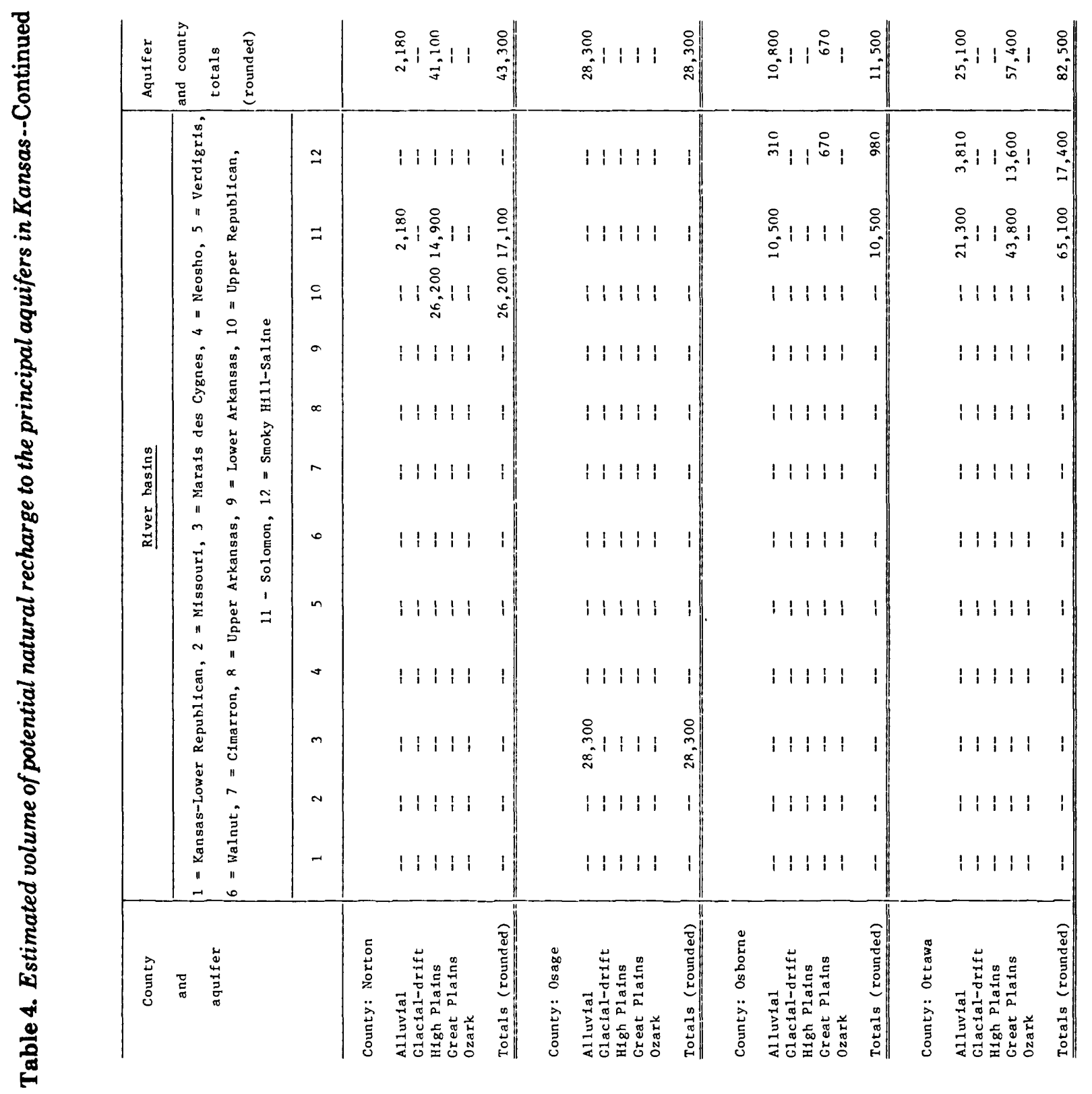




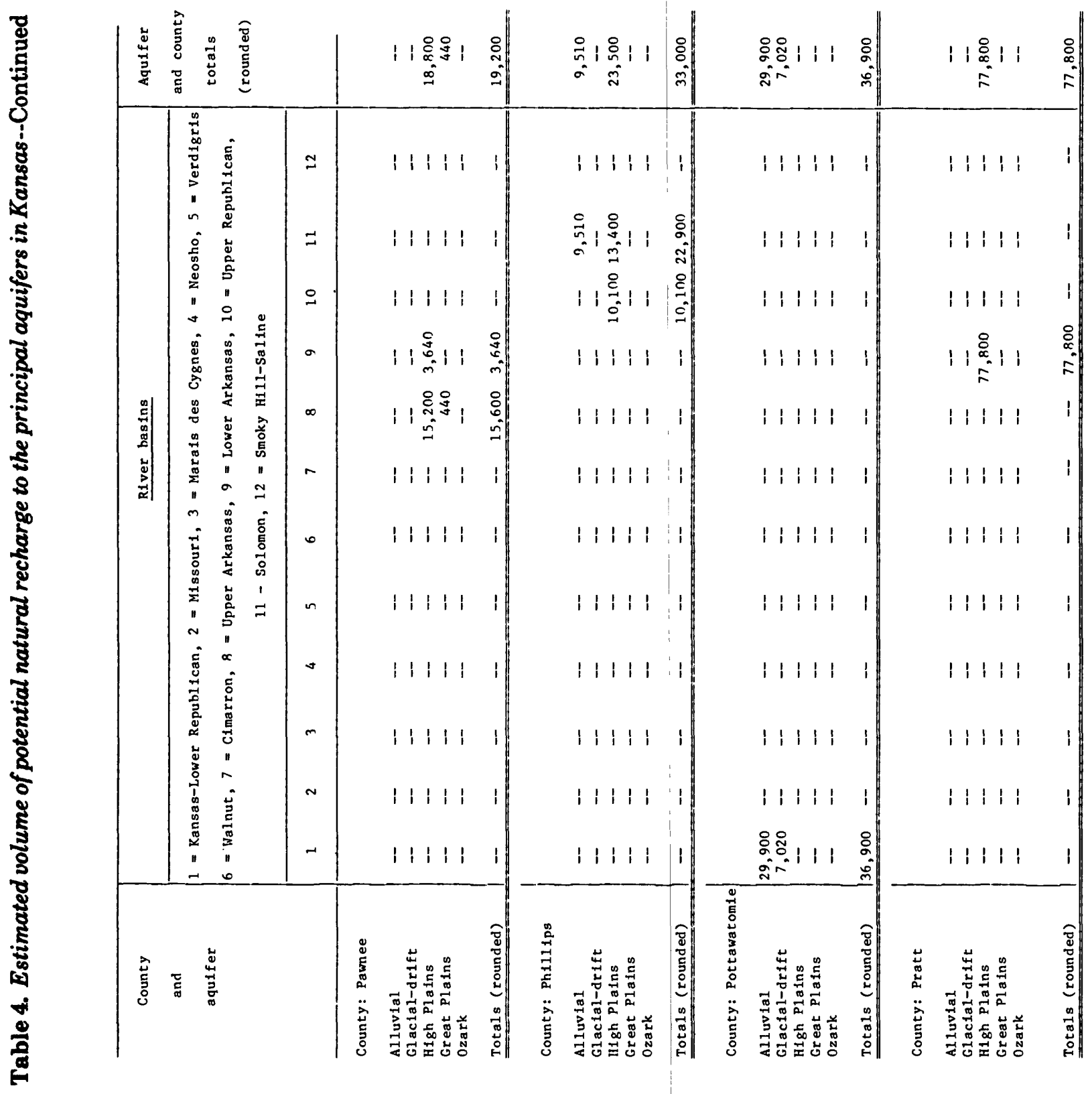




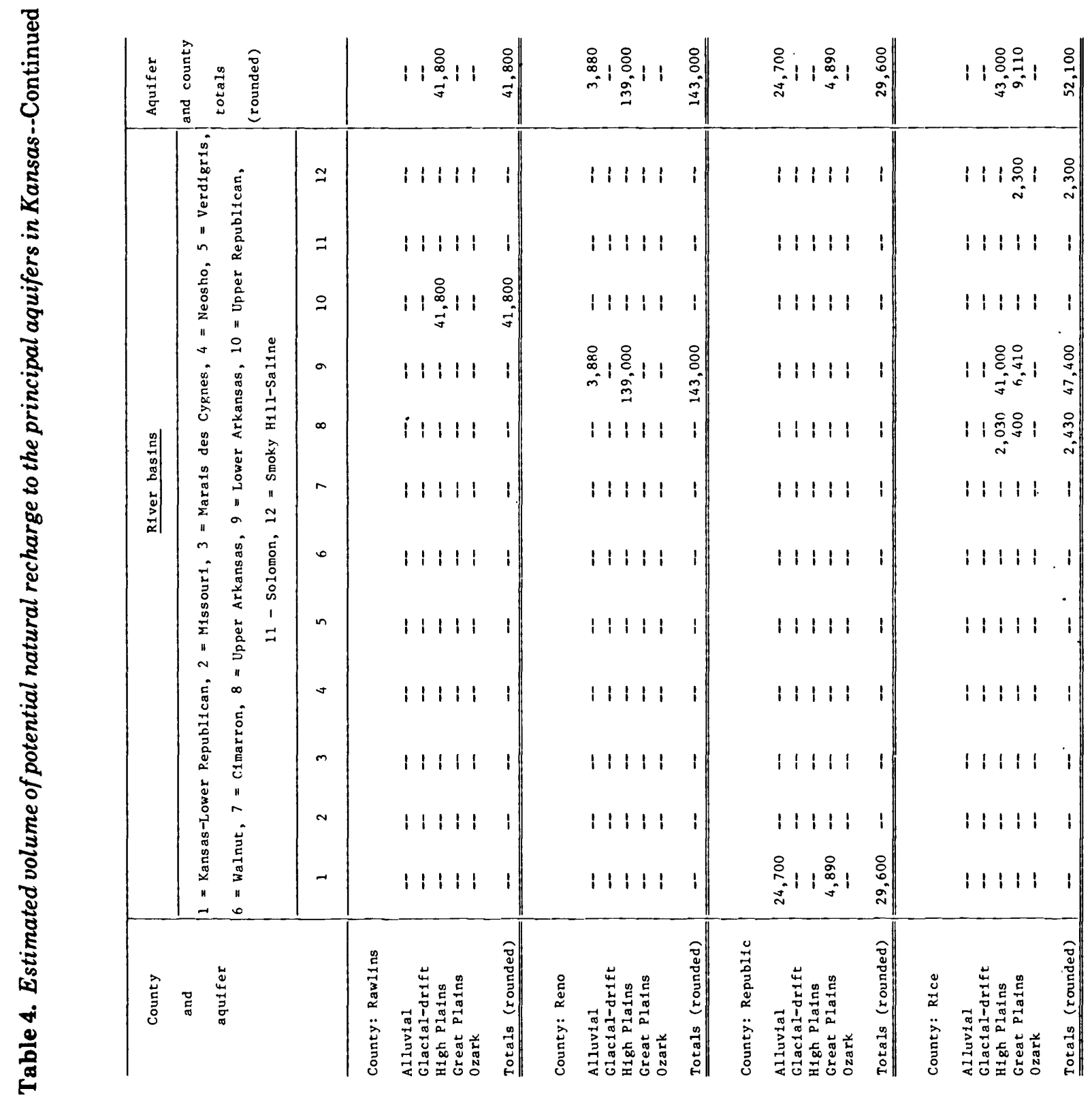




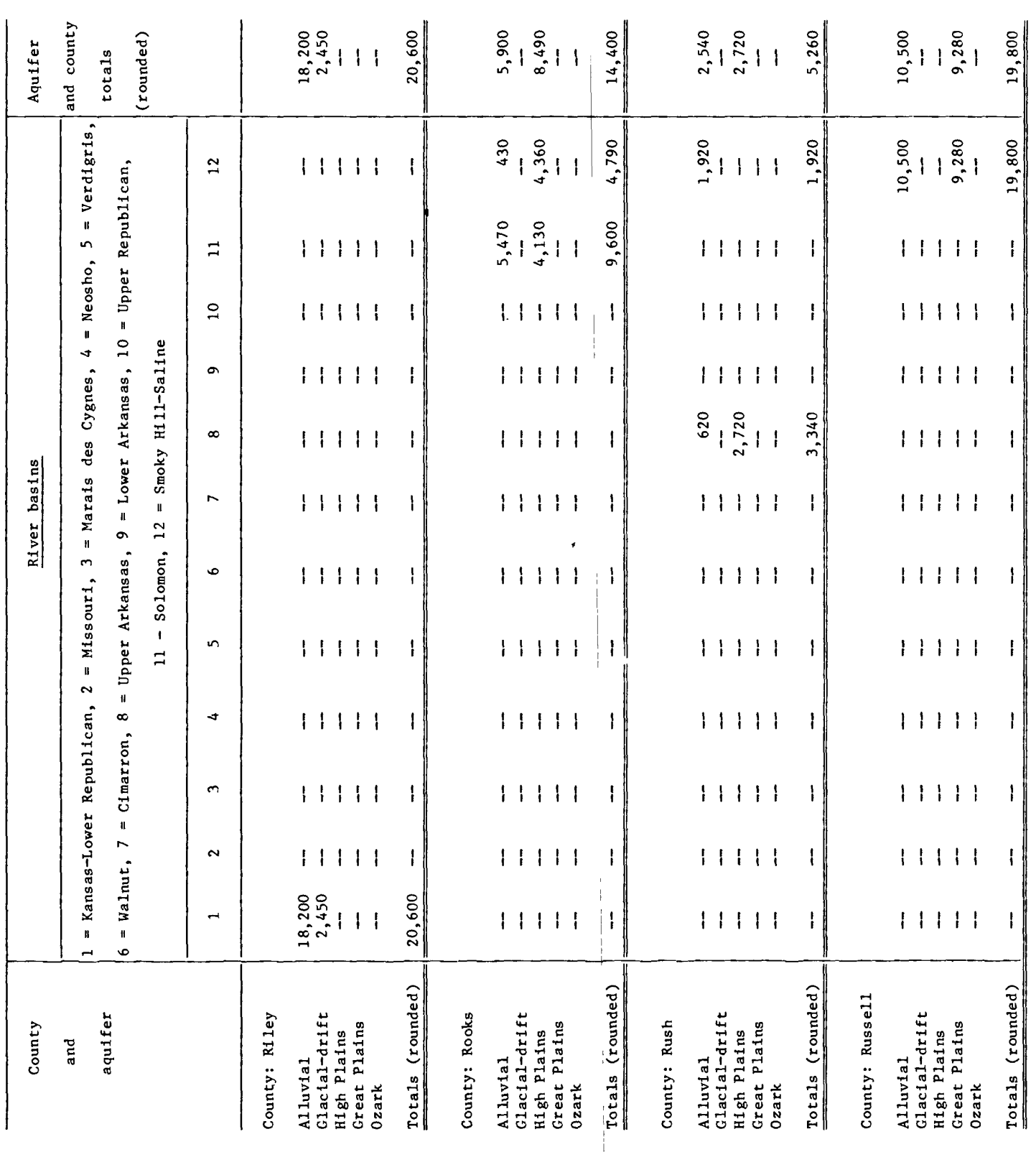




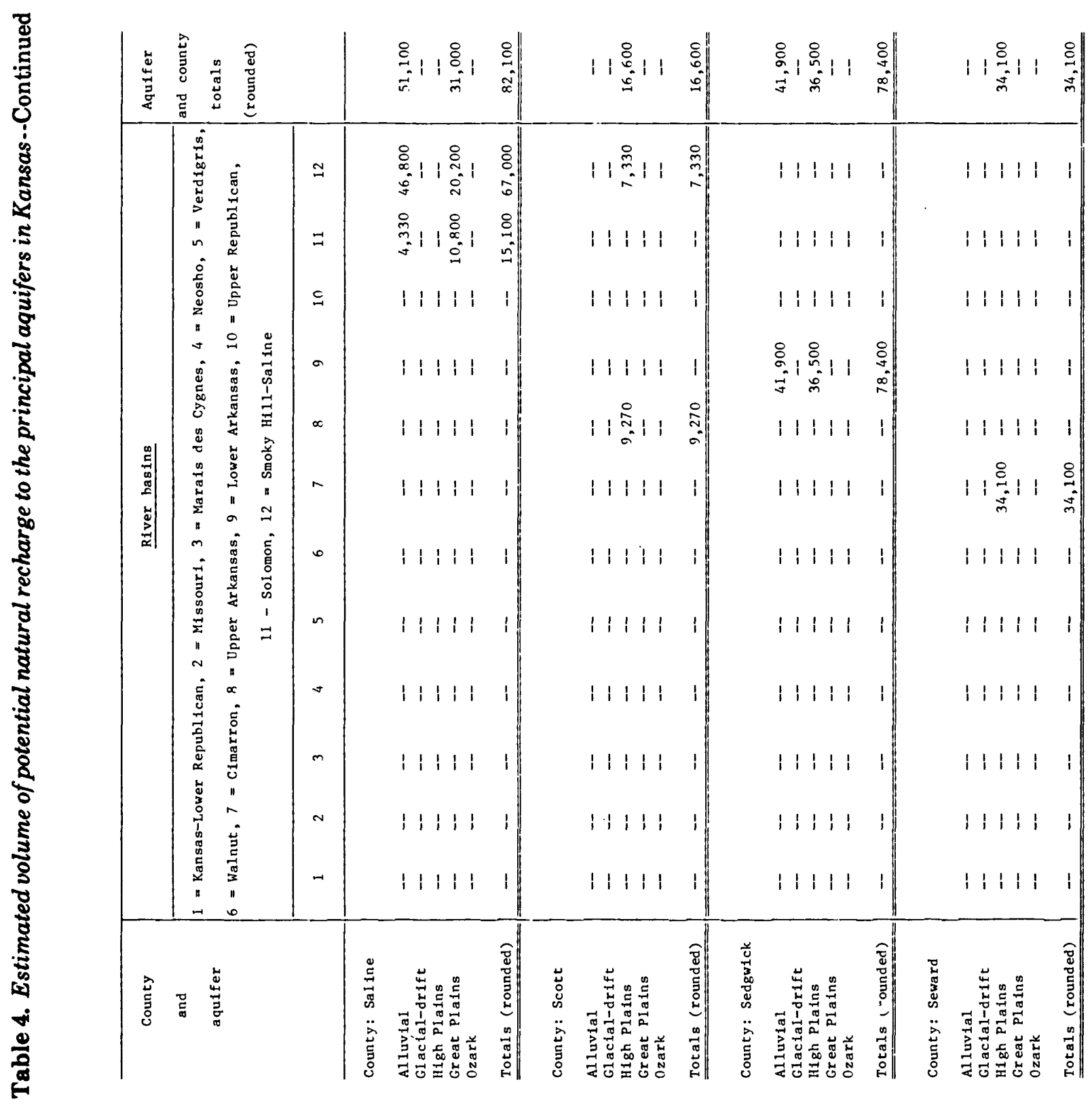




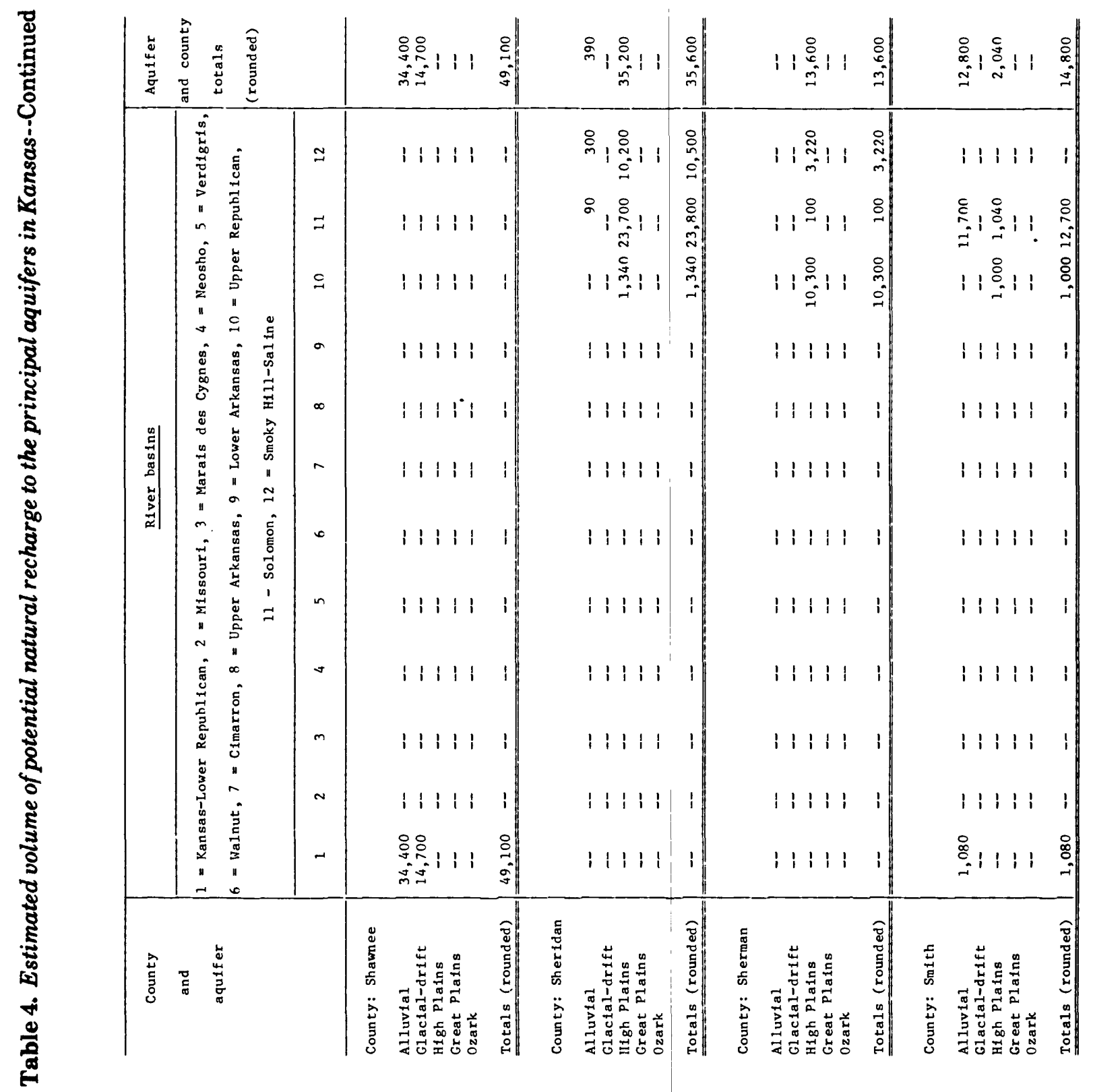




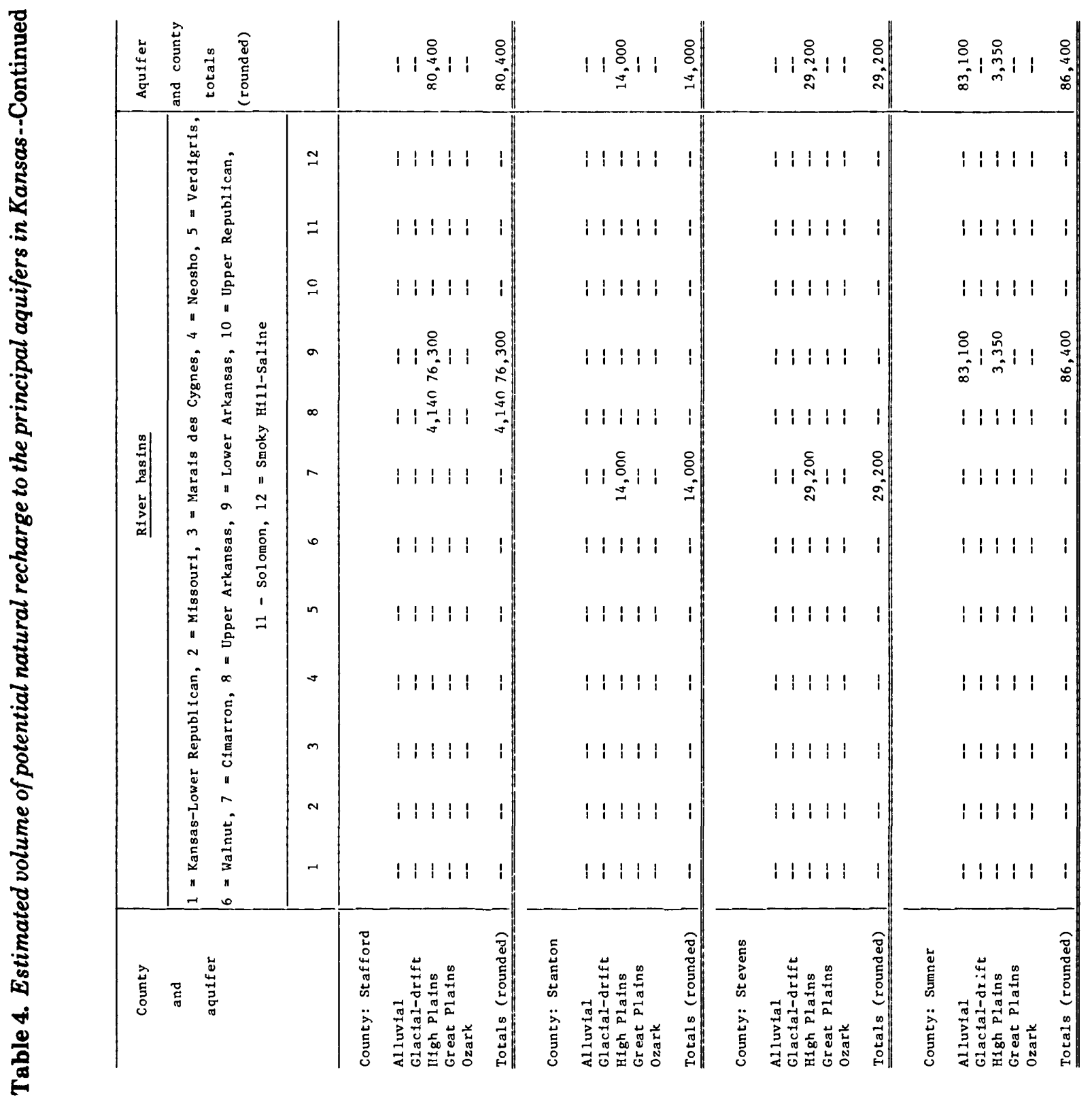




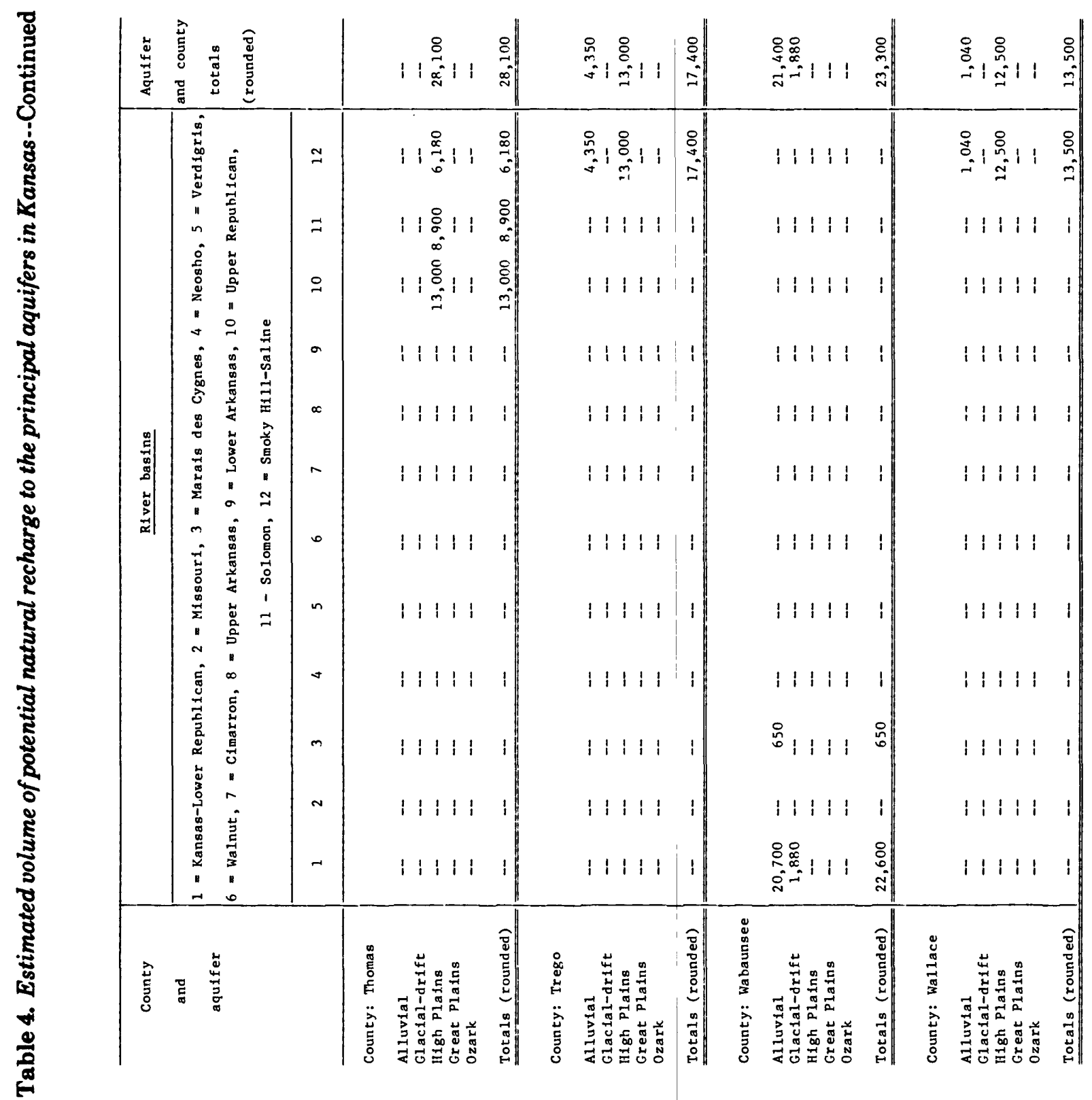




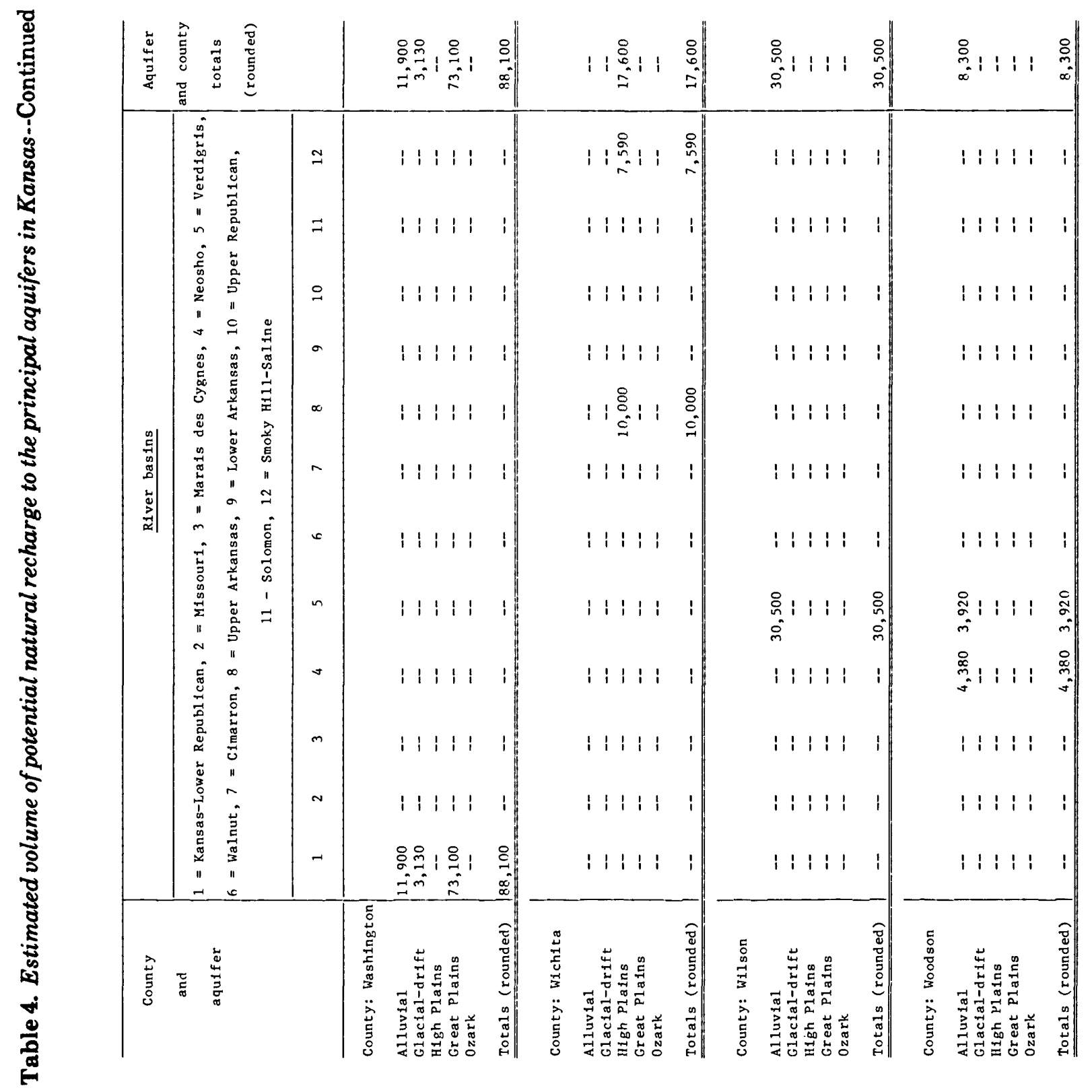




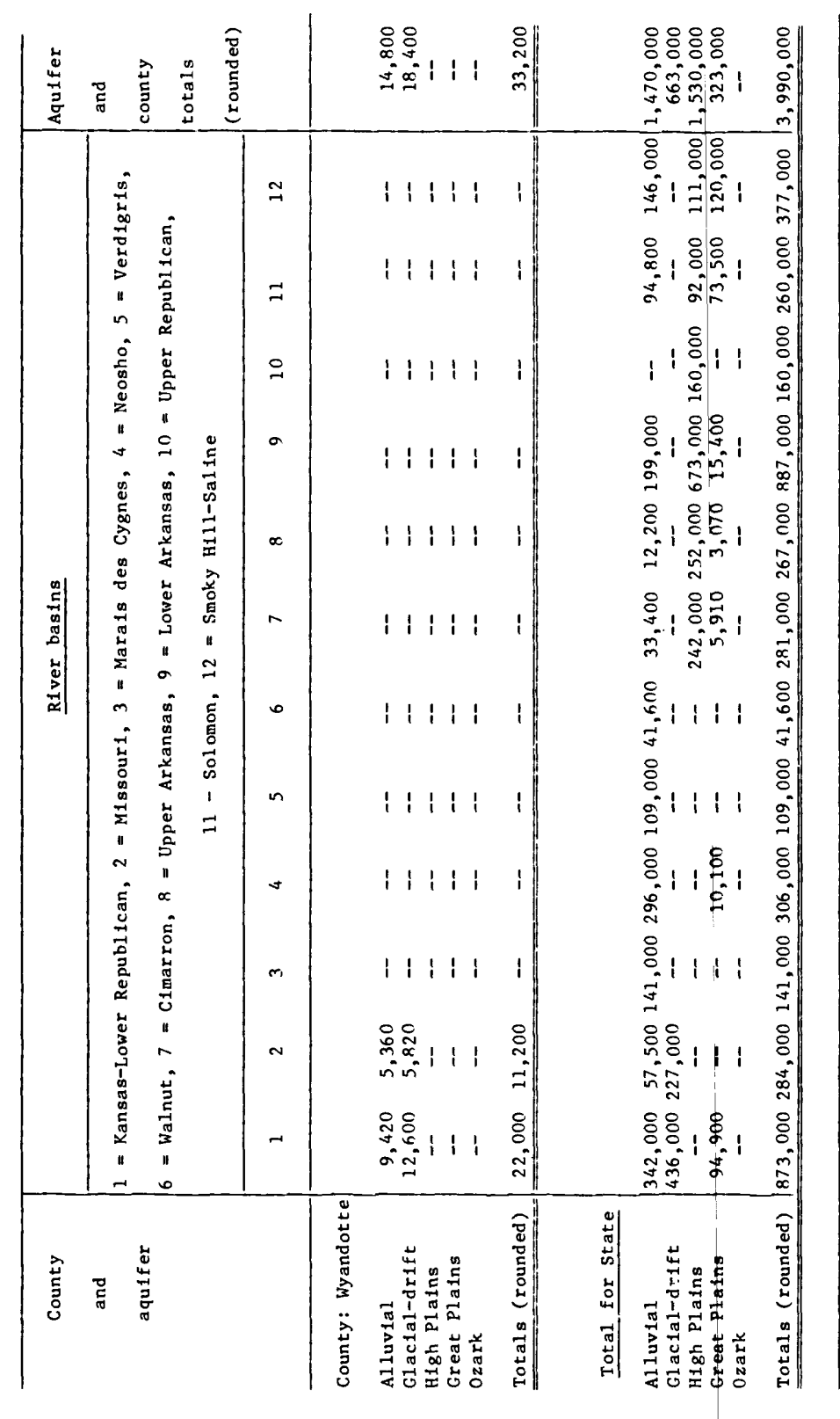

